\title{
STRUCTURAL MATERIALS.
}

\author{
BUILDING STONE.
}

\section{VARIEGATED MARBLE SOUTHEAST OF CALERA, SHELBY COUNTY, ALABAMA.}

By Charles Butts.

About $3 \frac{1}{2}$ miles a little south of east of Calera, Ala., is an outcrop of marble which is attracting some attention. The deposit was noted and described by McCalley, ${ }^{1}$ and in 1910 was visited by E. A. Smith, State geologist of Alabama, to whom the writer is indebted for information concerning one of the exposures. In 1910 the deposit was also examined at one point by the writer.

The exposure examined by the writer is one-fourth of a mile south of Buxahatchee Creek, in the NW. $\frac{1}{4}$ NE. $\frac{1}{4}$ sec. 8 , T. 24 N., R. 14 E., on property belonging to J. S. Evans, of Calera. (See sketch map, fig. 36, p. 222.) It is easily reached by wagon road from Calera. The exposure is on a steep bank near the head of a ravine opening into Buxahatchee Valley. A thickness of about 25 feet of marble is exposed for 50 feet along the side of the ravine. Below is an approximate section showing the stratigraphic relations of the marble.

Section in ravine $3 \frac{1}{2}$ miles southeast of Calera.

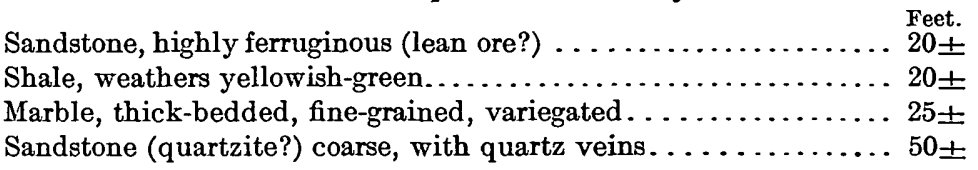

The sandstone at the base of the section can be followed north into the NW. $\frac{1}{4}$ sec. 4 , T. 24 N., R. 14 E., as shown in figure 36 . North

1 McCalley, Henry, Report on the valley regions of Alabama, pt. 2, Geol. Survey Alabama, 1897, pp 513,514 . 
of Buxahatchee it makes a high ridge, which is a good marker for the outcrop of the marble.

In the bed of Buxahatchee Creek the sandstone dips $20^{\circ}$ to $25^{\circ}$ E., and the overlying ferruginous sandstone dips $10^{\circ}$ to $15^{\circ} \mathrm{E}$. A quarter of a mile farther east, however, the dip becomes $40^{\circ}$ to $60^{\circ} \mathrm{E}$.

The geologic formation in which the marble occurs was classified as Montevallo (Lower Cambrian) by the Alabama Geological Survey. The writer concludes that these rocks are the same as those mapped by the Alabama Survey as Talladega (Ocoee) slates, which he thinks may include the metamorphosed equivalents of the Rome ("Montevallo") formation. The State geologist, E. A. Smith, informs the writer that he has long entertained this view of the equivalency of the "Montevallo" in this section with the "Talladega."

The marble is thick bedded, the layers being 3 to 4 feet thick. They are cut by joints that divide them into blocks of considerable size, and it seems probable that under good cover even larger blocks would exist. The dimensions of slabs or blocks that could be obtained would have to be determined by tests involving excavation and the actual working of representative samples of the rock. The rock is very fine grained and takes a high polish. Part of the layers are gray and part are variegated with deep red and pale pink, the whole stratum being composed perhaps of one-half of each kind. The color is due to a coating of iron oxide on the limestone grains. The variegated layers appear to prevail in the upper portion, the gray layers below. The rock is traversed by many white and bluishgray calcite veins, and here and there by thin stringers of small quartz grains. The variegation gives to the rock a highly ornamental effect when polished, and it would appear to possess superior qualities for decorative purposes.

There is another exposure of this marble about $1 \frac{1}{4}$ miles northeast of the one just described, in the NE. $\frac{1}{4}$ NW. $\frac{1}{4} \sec .4$, T. 24 N., R. 14 E., on land owned by J. W. Miller. For data concerning the marble at this point the writer is indebted to E. A. Smith, who says: "It shows a thickness of some 20 feet or more of varying shades of pink, chocolate, and red colors, alternating with white, sometimes in distinct bands, in some parts of rather uniform pink shade."

It is assumed that the stratum is continuous between the Evans and Miller properties, but no exposures are reported between them. The topography is such that a considerable body of marble could be obtained in an open-cut quarry, but ultimately the rock would have to be mined.

The outcrop on the Evans property is easily accessible to the Louisville \& Nashville Railroad, about 2 miles distant, as shown on the sketch map. 
Whether the marble could be exploited with profit is a question that would need careful consideration. Competition in the marble industry is great, and it would not be easy to establish a new enterprise in that line on a paying basis except under especially favorable circumstances, as has been shown by experience in other parts of the country in the case of marble of apparently superior quality for structural or decorative use. 


\title{
SUPPLEMENTARY NOTES ON THE COMMERCIAL GRAN- ITES OF MASSACHUSETTS.
}

\author{
By T. Nelson Dale.
}

\section{INTRODUCTION.}

The granites and granite quarries of Milford, Quincy, Rockport, and Becket, Mass., were described in a former bulletin of the Survey. ${ }^{1}$ In June, 1910, the remaining active granite quarries of the State were visited and the results of these supplementary studies are here given. The treatment of the subject is both scientific and economic, as it was in that bulletin and in Bulletins $313,404,430$, and 484, on the other New England granites.

The following scale of shades and texture has been used in all these papers. Shades: Very dark gray (Quincy "extra dark"); dark gray (Barre and Quincy "dark"); medium gray (Concord); medium to light gray (Hallowell); light gray (Barre "light"); very light gray (North Jay and Dummerston "white"); white, mottled with gray (Bethel). Textures: Coarse, with feldspars over 0.4 inch in diameter; medium, with feldspars under 0.4 inch and over 0.2 inch; fine, with feldspars under 0.2 inch; very fine, with feldspars under 0.1 inch.

As in the bulletins named, the number of each specimen described to which that of one or more thin sections correspond is given so that the descriptions can be verified by consulting the collections at the National Museum.

All the "granites" here described, as well as the others of Massachusetts described in Bulletin 354, are commercially classified and scientifically determined in the table on pages 286-287, which is therefore complete for this State. The total number of quarries described is 88 . Quarries producing only paving, underpinning, or crushed stone have been excluded, but the felsite quarry of Revere has been included, although it is not entered in the table.

1 Dale, T. N., The chief commercial granites of Massachusetts, New Hampshire, and Rhode Island: Bull. U. S. Geol. Survey No. 354, 1908, pp. 90-14l. 


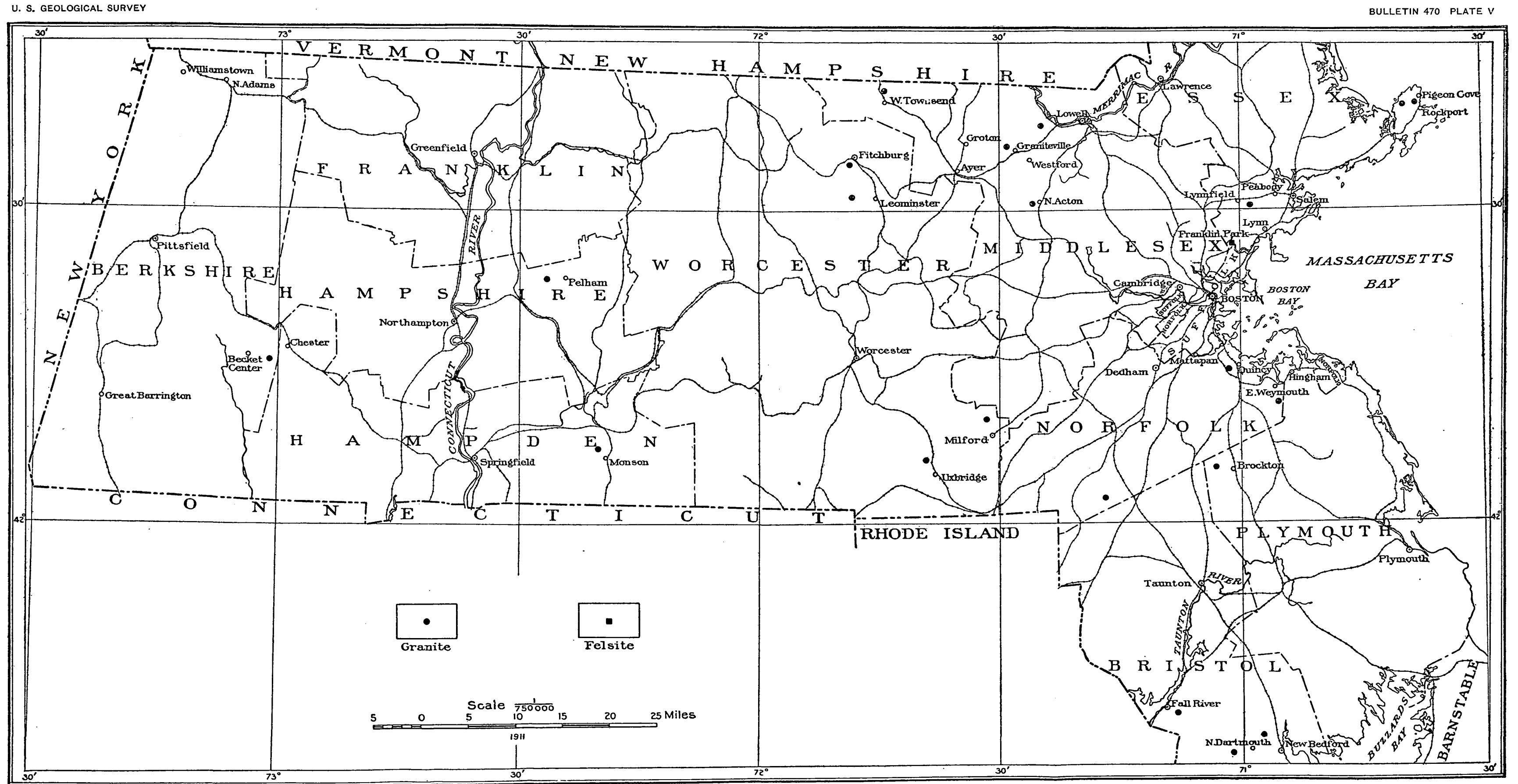

MAP OF MASSACHUSETTS, SHOWING GRANITE-QUARRYING CENTERS. 
The word "granite" in the title is used in its commercial sense and embraces a variety of igneous rocks. The local or trade names of the granites used in this paper have no significance as geologic formation names.

The elementary facts as to the origin, composition, physical properties, texture, and structure of granite, together with a summary of the methods of classifying, testing, and quarrying it, will be found in a form intended for general readers in Bulletin 354, pages 9-72. The definition of the mineral composition of granite given there (p. 11) should be revised so as to make the second or plagioclase feldspar include either one containing soda and lime, as in most granites, or one containing soda, as in some of the granites described in this paper.

This paper concludes the writer's work on the commercial granites of New England. It contains two petrographic determinations contributed by Dr. Whitman Cross, of the United States Geological Survey.

\section{LOCATION OF THE QUARRIES.}

The quarries to be described are in the towns of Dartmouth, Fall River, and New Bedford, Bristol County; Lynnfield and Peabody. Essex County; Monson, Hampden County; Pelham, Hampshire County; Acton, Groton, Westford, and Townsend, Middlesex County; Wrentham, Norfolk County; Brockton and Hingham, Plymouth County; Revere, Suffolk County; and Fitchburg, Leominster, and Uxbridge, Worcester County. The distribution of all the granitequarrying centers of the State is shown on the map (Pl. V).

\section{GENERAL CHARACTER OF THE GRANITES。}

The "granites" of these 42 quarries fall into 14 petrographic groups: Biotite granite gneiss (Uxbridge, Pelham); biotite granite, gneissoid (Fall River); biotite-muscovite granite, gneissoid (Dartmouth, New Bedford); muscovite-biotite granite gneiss (Groton, Oak Hill, Westford, Fitchburg); biotite-quartz monzonite (Townsend); biotite-quartz monzonite gneiss (Monson); muscovite-biotitequartz monzonite gneiss (Snake Meadow Hill, Westford); biotitemuscovite-quartz monzonite gneiss (Acton); hornblende granite (Wrentham); hornblende-augite granite (Lynnfield, Peabody); biotite-hornblende (or altered augite-hornblende) porphyritic granite (Brockton); mica diorite (Leominster); aplite (Hingham).

\section{GEOLOGIC OBSERVATIONS AT QUARRIES.}

At 12 of these quarries matters of special geologic interest were noted. These follow under various headings. 


\section{INCLUSIONS AND CONTACTS.}

The muscovite-biotite granite gneiss of the Rafferty quarry, in Groton (p. 264), contains several inclusions, the largest of which, triangular in outline, measures 30 feet on one side and 8 feet on another. This rock (specimen D, XXX, 100, a) is a dark-gray biotite granite gneiss with porphyritic feldspars up to 0.6 inch. Its quartz is granulated like that of the inclosing gneiss. Both gneisses are crossed by a pegmatite dike, and aplite occurs also in both.

The muscovite-biotite-quartz monzonite gneiss of the Palmer quarry, in Westford (p. 271), has a lenticular inclusion, 3 feet by 3 inches, of very fine grained, evenly foliated quartz-biotite schist with some cloudy particles which may be much kaolinized feldspar; also a little muscovite and zoisite. This rock may be of sedimentary origin. The gneiss at the Oak Hill quarry, in the same town (p. 267), also contains small dark finely banded inclusions.

The quartz monzonite of Barker Hill, in West Townsend (p. 273), has inclusions up to 4 feet across of a fine-grained biotite gneiss, probably a quartz-mica diorite gneiss like those in the quartz monzonite of the O'Rourke quarry, in Brookline, N. H., about 5 miles to the northeast. ${ }^{1}$

The quartz monzonite gneiss of the McCarthy quarry, in North Acton (p. 263), is in contact with a very dark grayish, fine textured, finely banded, and pegmatized quartz-mica diorite gneiss with oligoclase (specimen D, XXX, 112, b). Within a few feet of the contact is an inclusion of the diorite gneiss

\section{APLITE DIKES.}

The gneissoid biotite granite of the Savoie quarry, in Fall River (p. 252), is crossed by two aplite dikes. One (specimen D, XXX, $118, a), 10$ feet wide, is of light pinkish-gray color and fine, evengrained texture. Its second feldspar is albite (soda feldspar), somewhat micasized and epidotized. Its biotite is chloritized. The other (specimen D, XXX, 118, b), up to 2 feet thick, is of dark brownishgray color and semiporphyritic texture, its smaller particles generally arranged about the larger. Its second feldspar is also albite.

The biotite granite gneiss of the Blanchard quarry, in Uxbridge (p. 283), has aplite dikes up to 3 feet thick.

The muscovite-biotite granite gneiss of the Oak Hill quarry, in Westford (p. 267), has whitish aplite dikes with longitudinal bands of black tourmaline 0.2 inch wide.

A very unusual dike of aplite crosses the mica diorite of the Leavitt quarry, in Leominster (p. 283). (See fig. 38.) It is of light-gray and bluish-gray color. Its broadest part consists of over 150 meandering 
parallel bands of these alternating shades (specimens D, XXX, 110, b, c), many of them bordered with microscopic prisms of black tourmaline with their main axis across the band. The meanderings of these bands resemble the plications of a metamorphic stratified rock. The aplite contains here and there clear feldspars up to an inch long. In thin section it resembles a quartz monzonite, its constituents, in descending order of abundance, being oligoclase-albite, quartz, microcline, and black tourmaline in minute prisms. The accessory minerals are apatite in needles and particles (abundant), pyrite, garnet, and flakes of muscovite (rare). The yellowish tinge of some of the bands is probably due to the oxidation of the pyrite. A few of the bands are pegmatite without tourmaline but with biotite, a little muscovite, and ilmenite (?) surrounded by leucoxene.

The banding of this aplite dike may be ascribed to a gradual enlargement of the fissure and the deposition of aplite on either side, as in banded mineral veins. The meandering or plication of the bands and the transverse orientation of the tourmaline prisms are possibly due to one cause. Other smaller dikes of aplite are parallel to this one and some of aplite and of pegmatite intersect the main dike.

Finally should be mentioned the considerable area of pyritiferous aplite quarried in Hingham (p. 276). This is of light, slightly greenish-gray color and scarcely developed sheet structure but with many headings

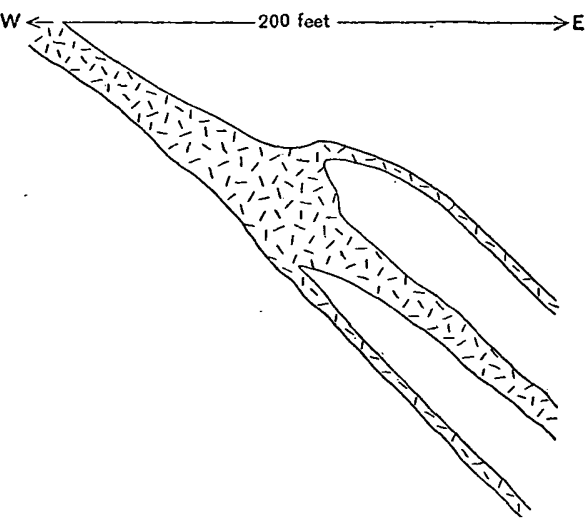

FIGURE 38-Approximate borizontal section of banded aplite dike in diorite, Leavitt quarry, Leominster, Mass.

showing rusty faces from the limonitization of the pyrite. This rock also resembles a quartz monzonite, with these constituents in descending order of abundance: Oligoclase-albite, quartz, microcline, and very little biotite mostly chloritized and associated with epidote. The accessory minerals are pyrite and magnetite. As the stone is extremely hard its percentage of quartz must be high.

\section{BASIC DIKES.}

Several interesting basic dikes were noted.

The elongated porphyritic biotite granite gneiss of the Blanchard quarry, in Uxbridge (p. 283), is cut by an amphibolite dike up to 18 inches thick, the schistosity of which strikes at an angle of $33^{\circ}$ with that of the inclosing gneiss. This dike consists of feather-rimmed crystals of hornblende up to an inch in length in a matrix of biotite 
with interspersed quartz grains and minute slender crystals or strings of lenses of zoisite. In places, however, along the edges the matrix is of quartz, biotite, epidote; and oligoclase-andesine. The dike was originally a porphyritic mica diorite.

At the Sullivan quarries, near New Bedford (p. 253), is an interesting complex of dikes of various sorts and ages whose courses are shown in figure 39. The rock is a slightly gneissoid biotite-muscovite granite of light pinkish gray color. The central dike A, with northeast course and up to a foot thick, is a dark-greenish chlorite schist (specimen D, XXX, 121, c) consisting of chlorite, probably after hornblende, in parallel arrangement, micasized plagioclase, quartz, and microcline. Its accessory minerals are pyrite, magnetite, purple fluorite, apatite, and biotite. Secondary: Epidote, carbonate, and hematite from the magnetite. This dike was evidently originally a diorite. Dike $\mathrm{B}$ on the south wall, with a N. $70^{\circ} \mathrm{E}$. course and a dip

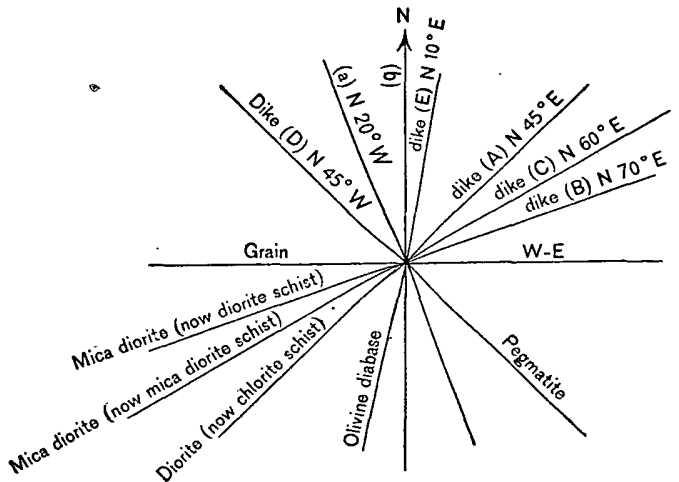

Figure 39.-Structure and dikes at Sullivan quarries, New Bedford, Mass. of $60^{\circ} \mathrm{N} .20^{\circ} \mathrm{W}$., over 2 feet thick, is a dark-grayish mica diorite schist (specimen $121, \mathrm{~d}$ ), consisting, in descending order of abundance, of andesine, biotite, epidote, and muscovite. This was originally a mica diorite. Dike $\mathrm{C}$, on the north wall, with a N. $60^{\circ} \mathrm{E}$. course, and vertical dip, up to 3 feet thick, is a black, fine-grained mica diorite schist (specimen 121, f), consisting, in descending order of abundance, of biotite, oligoclase, microcline, quartz, and epidote. This also was originally a mica diorite. It differs from dike B in being more micaceous and in containing no muscovite. The edge of this dike (specimen 121, g), for a thickness of a few inches, consists of brecciated grayish feldspars up to 0.3 inch in diameter in a matrix of biotite. At the extreme edge this breccia passes into a mass of the same feldspar with a little quartz and still less biotite. The more glassy rim of the dike resisted the pressure which brecciated its inner border and converted its central part into a schist. Dike D, near the west wall, with a northwest course and steep dip, 3 inches thick, is pegmatite. It intersects the central chlorite schist (diorite) dike. Finally, dike E, on the west wall, with a N. $10^{\circ} \mathrm{E}$. course, up to 2 feet thick, is a diabase (specimen 121, e) with ophitic texture, consisting, in descending order of abundance, of andesine, pyroxene, 
serpentine (probably after olivine), and magnetite or ilmenite with a little carbonate and biotite. This was presumably an olivine diabase.

The evidence from these dikes shows that the granite was injected with dikes of diorite and mica diorite. Later it and the dikes were crossed by pegmatite. After dynamic metamorphism had altered the diorites to schists they were traversed by a diabase dike in which the only change has been the serpentinization of the olivine and the micasization of the andesine. ${ }^{1}$

As there is a marked difference between the schistosity of the diorite and that of the granite, which is but slightly gneissoid, it is evident that the dynamic metamorphism which brought about the schistosity of the dikes was produced by the pressure of their granite walls. The same thing was noticed as to certain dikes in the granites of Milford, Mass., and has also been recently observed by geologists of the British Geological Survey in Ross-shire, Scotland. ${ }^{2}$

Another basic dike noticed in these quarries was an altered but not metamorphosed lamprophyre, in the gneissoid biotite granite of the Beattie \& Wilcox quarry, at Fall River (p. 249), which Dr. Whitman Cross, of the United States Geological Survey, determines as vogesite. It has much augite and brown hornblende, biotite, and magnetite in a feldspathic base, probably of orthoclase, also a few porphyritic crystals of olivine altered to serpentine.

There is also a slightly altered diabase dike crossing the aplite of the Miller quarry, in Hingham (p. 279).

\section{QUARTZ VEINS BANDED WITH FELDSPAR.}

At the Blanchard quarry, in Uxbridge (p. 283), the biotite granite gneiss is crossed by veins or dikes of medium smoky quartz banded lengthwise with feldspar (specimen D, XXX, 114, c). The feldspar bands are from 0.2 to 0.5 inch wide and the quartz from 0.5 to 1.5 inches. The feldspar is microcline. The quartz contains many sheets of cavities parallel to bands and vein, also a few such sheets crossing the others at right angles. These sheets, where most abundant, are from 0.25 to 1.33 millimeters apart. The longitudinal sheets of cavities are continued in outjutting parts of the adjacent feldspars as cracks. Such veins are to be regarded as a variety of pegmatite in which quartz and feldspar were deposited alternately. ${ }^{3}$

\footnotetext{
1 Should what was taken to be an elongated segregation in the biotite granite of the Redstone quarry, at Westerly, R. I. (Bull. U. S. Geol. Survey No. 354, 1908, p. 202), prove to be a diorite schist dike, then some of the relations there would duplicate those at New Bedford, for at the Redstone quarry the schist is also crossed by pegmatite and the pegmatite by a diabase dike.

2 See Dale, T. N., Bull. U. S. Geol. Survey No. 354, 1908, pp. 59, 60. Clough, C. T., Crampton, C. B., and Fleet, J. S., The augen gneiss and Moine sediments of Ross-shire: Geol. Mag., new ser., decade 5, vol. 7, London, August, 1910, p. 344.

3 See section on the relation of rift and grain to sheets of cavities, Bull. U. S. Geol. Survey No. 354, 1908, pp. 42-47.
} 


\section{HEADINGS ON A MINUTE SCALE.}

The hornblende granite of High Rock, in Wrentham (Curry quarry, p. 274), besides the usual sheet and joint structure, has steep headings at irregular intervals in its upper part. These are only 5 to 10 feet deep and several feet wide, differing from ordinary headings in the closeness of their joints, which are only 1 to 2 inches apart. This structure is analogous to "shake structure," which, however, is parallel to the sheets. There are no joints in this quarry parallel to these minute headings, which are probably to be attributed to peculiar vibratory strains.

\section{GREEN GRANITE.}

New England olive-green granites from Rockport, Mass., ${ }^{1}$ Redstone, ${ }^{2}$ and Kilkenny, N. H., ${ }^{3}$ and Mount Ascutney, in Windsor, Vt., ${ }^{4}$ have already been described. That of Rockport is a hornblende granite, that of Redstone a biotite-hornblende granite, that of Kilkenny an augite-biotite granite, and that of Windsor a hornblende-augite granite. The greengranite of Peabody and Lynnfield (pp. 255-258) is also a hornblende-augite granite, but contains less quartz and more dark silicates. It is analogous to the riebeckite-ægirite granite of Quincy, but its black silicates contain extremely little or no soda. ${ }^{5}$

Washington ${ }^{6}$ refers to this green granite in these words:

The rocks belonging to this class were first noticed by Wadsworth in 1885 and were later described more in detail by Sears. Rosenbusch has expressed the opinion that these are related to the akerite type of syenites, a keen observation which my study of the rocks fully confirms. These rocks are found chiefly in the eastern part of Essex County, in Essex, Beverly, Manchester, Gloucester, and on Cape Ann. * * * The color even of the freshest specimens is greenish, which varies in shade from a dark greenish black to a light shade of greenish gray.

In common with the green granites of Rockport and Redstone, that of Peabody and Lynnfield contains considerable allanite, to the oxidation of which the green color is partly due.?

SHEAR ZONES.

Zones along which numerous microscopic parallel meandering fractures have been made and shearing has occurred, giving rise to secondary minerals and plicating the lamellæ of plagioclase, were observed at one of the Fall River quarries. (See p. 250.)

1 Bull. U. S. Geol. Survey No. 354, 1908, pp. 124, 135.

2 Idem, pp. 182, 183.

8 Bull. U. S. Geol. Survey No. 430, 1910, pp. 355-356.

4 Bull. U. S. Geol. Survey No. 404, 1909, pp. 116-119.

5 Bull. U. S. Geol. Survey No. 354, 1908, pp. 91-93.

6 Washington, H. S., The petrographical province of Essex County, Mass.: Jour. Geology, vol. 6, 1898, p. 787. See also Sears, J. H., The physical geography, geology, mineralogy, and paleontology of Essex County, Mass., Salem, Mass., 1905, pp. 178, 190.

7 Bull. U. S. Geol. Survey No. 354, 1908, p. 52, fig. 3. 


\section{ECONOMIC NOTES.}

Of special economic interest is the utilization of the extremely hard and almost sheetless aplite of Hingham, which is full of limonitic headings. (See p. 278.) For a number of years there has been a demand in the vicinity of Boston for rusty seam-faced granite for the exteriors of buildings, and quarries were opened in Hingham to supply such stone. It is now furthermore proposed to transform these ordinary obstacles to granite quarrying into things of beauty by carving bas-reliefs of leaves and garlands on the iron-stained joint faces. This is done by cutting away the sap or rusty part, which is usually from one-eighth to one-fourth inch thick, so that the leaves in brown project on a light-grayish ground. Blocks thus worked can be utilized in ornamental bands on exteriors. Sap-faced sheets are utilized as a by product at one of the Rockport quarries. ${ }^{1}$ One of the Hingham quarries fills orders for sap-faced coigns with angles of $90^{\circ}$ or $120^{\circ}$. The aplite, owing to its exceptionally great compressive strength, has also been found useful for keystones in tunnel arches.

Although felsite porphyry is not a granite, it is a related igneous rock of important constructional value. The purplish-brown felsite porphyry of Black Ann Hill, in Revere (p. 279), has been found to be valuable for concrete construction, and a very large quantity of it was used in the East Boston tunnel. Tests made by the engineer of the Boston Transit Commission show that beams of 30-inch span, made with broken stone and the felsite dust from the crusher (presumably with $\frac{1}{4}$-inch screenings), have an average breaking strength 15.74 per cent higher than beams made with the same broken stone and sand. (See p. 280.) The superiority of felsite dust to sand for concrete is probably due to the fact that the angularity of the vitreous fragments is greater than that of water-rolled ouartz and feldspar grains.

A noticeable feature at many of the granite quarries is the recent addition of a stone crusher for turning the small waste into material for concrete, and even the "dust" from the crushers is in demand. Most of the waste is now consumed in paving blocks and crushed stone.

Some general remarks on Massachusetts granites are given on page 288 .

\section{THE GRANITES AND QUARRIES.}

The granite and quarry descriptions are arranged alphabetically by counties and townships.

1 See Bull. U. S. Geol. Survey No. 354, 1908, pp. 69, 125, and for the cause of the stain pp. 56-58. 


\section{BRISTOL COUNTY.}

\section{DARTMOUTH.}

\section{DARTMOUTH QUARRY.}

The Dartmouth quarry is in Dartmouth Township, three-fourths of a mile east of Westport Mills and $8 \frac{1}{4}$ miles southeast of the Fall River steamboat wharf. (See map of Fall River quadrangle, U. S. Geol. Survey, and Pl. V.) Operator: New Bedford \& Dartmouth Granite Co., 81 Austen Street, New Bedford, Mass.

The granite (specimen D. XXX, 122, a), "Dartmouth," is a gneissoid biotite-muscovite granite of very light buff-gray color and of very slightly gneissoid, medium inclining to coarse texture with feldspars up to 0.5 inch and mica up to 0.1 inch. Its constituents, in descending order of abundance, are cream-colored, translucent microperthite (potash feldspar (microcline), minutely intergrown with lime-soda feldspar (oligoclase-albite) and somewhat kaolinized); pale, smoky quartz, with cavities, in sheets; clear to translucent soda-lime feldspar (oligoclase-albite); but little kaolinized; and muscovite (white mica) and biotite (black mica) in about equal amounts. Accessory: Garnet. Secondary: Kaolin and carbonate. It shows extremely little effervescence with hydrochloric-acid test. This is a serviceable constructional stone with feeble mineral contrasts.

The quarry, opened in 1903, is about 150 by 100 feet and 30 feet deep, with a working face 45 feet high on the west. The stripping consists of 5 feet of sand.

The sheets, from 1 to 12 feet thick, are about horizontal. The joints, all discontinuous, are of three sets: Set $a$ strikes N. $75^{\circ} \mathrm{E}$., dips $75^{\circ} \mathrm{S} .15^{\circ} \mathrm{E}$; ; on the north and south walls only. Set $b$ strikes north, dips $50^{\circ} \mathrm{E}$., is spaced 3 to 10 feet; forms the west wall. Set $c$ strikes N. $25^{\circ}$ W. dips $65^{\circ}$ N. $65^{\circ}$ E.; one only. The rift is horizontal and the grain vertical with $\mathrm{N} .60^{\circ} \mathrm{E}$. course. There are small pegmatite and smoky quartz dikes with $\mathrm{N} .60^{\circ} \mathrm{W}$. courses. Rusty stain is up to 3 inches thick on sheet surfaces, diminishing at the bottom of quarry.

The plant comprises three derricks, two hoisting engines, two steam drills, an air compressor (capacity, 100 cubic feet of air per minute), seven air-plug drills, and two steam pumps.

Transportation is by cart to New Bedford, $5 \frac{1}{2}$ miles.

The product is used for local buildings, curbing, and paving. Specimen: Trimmings on Lunds Corner schoolhouse, New Bedford.

\section{ALFRED DENAULT QUARRY.}

The Alfred Denault quarry is in Dartmouth Township, just west of the Dartmouth quarry, and its granite is identical.

This is a small opening begun in 1910. The stripping is not over 18 inches of sand. In June the first sheet had been exposed to a depth of 5 feet. 
The plant comprises a hand derrick and hoisting engine, and the product is curbing.

FALL RIVER.

BEATTIE \& WILCOX QUARRY.

The Beattie \& Wilcox quarry is in the city of Fall River, near. Watuppa Pond and the railroad, $2 \frac{1}{2}$ miles southeast of the steamboat wharf. (See map of Fall River quadrangle, U. S. Geol. Survey.) Operators: Beattie \& Wilcox, 840 Bedford Street, Fall River, Mass.

The granite is of two colors. One (specimen D, XXX, 116, a), "Fall River pink," is a gneissoid biotite granite of medium pinkishgray color, with black spots, and of gneissoid, coarse, inclining to medium texture, with feldspars up to 0.5 inch and mica up to 0.4 inch. Its constituents, in descending order of abundance, are pinkish microperthite (potash feldspar (orthoclase and microcline), minutely intergrown with soda-lime feldspar); milky quartz, granulated (particles mostly under 0.5 millimeter), with some cavities in sheets; milkwhite soda-lime feldspar (oligoclase-albite), a little micasized and epidotized; biotite (black mica), mostly chloritized; and a little bleached biotite or muscovite. Accessory: Garnet and titanite. Secondary: Epidote, usually about the biotite, a white mica, chlorite, very little carbonate, and hematite stain. Some of the second feldspar has bent lamellæ. It shows no effervescence with hydrochloricacid test.

The rock of the other color (specimen D, XXX, 116, b), "Fall River gray," is a gneissoid biotite granite of light buif-gray color with inconspicuous black spots and of gneissoid, medium inclining to coarse texture, with feldspars up to 0.4 inch and mica up to 0.3 inch. Its constituents are the same as in the "pink," except that the microperthite is pale buff to pinkish, the second feldspar is light greenish, and the granulated quartz is clear and colorless, its particles measuring up to 0.75 millimeter. Among the secondary minerals is a little limonite stain. No carbonate detected nor effervescence.

These granites have in places flowage bands in which one band contains many more than the average of biotite spots, and the next contains many less and is also finer grained than the general mass, resembling an aplite.

These are very suitable granites for massive structures. The pink has more mineral contrasts than the other.

The quarry, opened in 1893, is about 400 by 200 feet and 10 to 40 feet deep.

The sheets, from 18 inches to 16 feet thick, undulate horizontally. Joint courses, etc., are shown in figure 40 . Set $a$ dips steeply N. 70 W., is spaced 50 feet, forms the west-southwest wall and a heading 20 feet wide 50 feet east of it. Set $b$, vertical, is spaced 20 to 200 feet. 
The flowage bands described dip steeply S. $30^{\circ} \mathrm{W}$. Shear zones dip $65^{\circ} \mathrm{NW}$., measure up to an inch in width, and are spaced 2 to 3 feet. The extremely fine, roughly parallel meandering planes of dark schistose material within the zones are fractures filled in their wider parts with epidote, carbonate, and muscovite. Veinlets of quartz cross the feldspars, about which there is some granulation. The lamellæ of the soda-lime feldspars are much bent, and some are even minutely plicated. The rift is horizontal, and the grain dips about like the joints of set $a$. A black, extremely fine grained basaltic dike, described on page 245; is 6 inches to 4 feet thick and weathers spheroidally. The "sap" is 1 to 8 inches thick on sheet surfaces.

The plant comprises three derricks, two hoisting engines, two steam drills, a steam pump, and a stone crusher of 75 tons daily capacity.

The product meets local demands mostly. Specimens: Armory, city library, Flint mills, Fall River; Banigan Chapel, in cemetery of

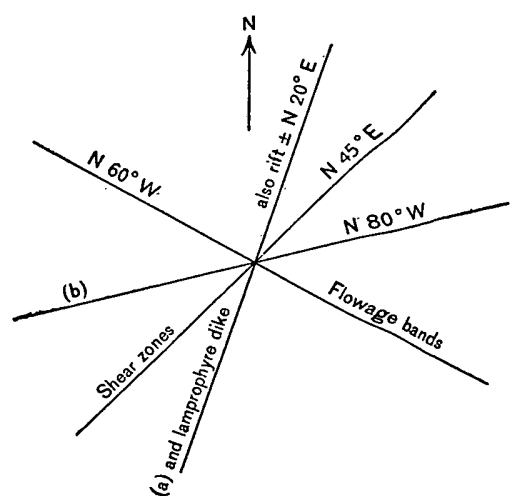

FIGURE 40.-Structure at Beattie \& Wilcox quarry, Fall River, Mass.

Pawtucket; "Stone bridge" to Rhode Island and naval training station, Newport, R. I.

\section{BEATTIE QUARRY.}

The Beattie quarry is in Fall River, $1 \frac{1}{2}$ miles west of the steamboat wharf. Operator: William H. Beattie, 33 North Quarry street, Fall River, Mass.

The granite is of two colors. One (specimen D, XXX, 117, a), "Fall River pink," is a gneissoid biotite granite of light pinkish-gray color with black spots and of slightly gneissoid, coarse texture, with feldspars and mica up to 0.5 inch, the mica exceptionally reaching 0.6 inch. Its constituents, in descending order of abundance, are pinkish microperthite (potash feldspar (microcline and orthoclase), some of it epidotized, minutely intergrown with soda-lime feldspar); clear, colorless quartz, granulated, with particles mostly under $0.5 \mathrm{inch}$, and with cavities, some in sheets, and rutile needles; and greenish to milkwhite soda-lime feldspar (oligoclase-albite), micasized and epidotized, some of its particles with bent lamellæ. Accessory: Allanite, zircon, rutile. Secondary: Fibrous muscovite stringers, another white mica, epidote, carbonate. It effervesces with hydrochloric-acid test.

The rock of the other color (specimen D, XXX, 117, b), "Fall River gray," is a gneissoid biotite granite of light-gray shade with conspicuous black and greenish spots and of slightly gneissoid, coarse inclining to medium texture. Its constituents, in descending order of abundance, are translucent grayish microperthite (potash feldspar (orthoclase and microcline), minutely intergrown with soda-lime feldspar); 
faintly purplish milky quartz, granulated, with particles under 0.5 inch and with cavities; gray to pale greenish, not translucent sodalime feldspar (oligoclase-albite), micasized and epidotized; biotite (black mica), some chloritized, generally with epidote; and a little bleached biotite or muscovite. Accessory: Allanite, garnet, and magnetite (very little). Secondary: Carbonate, a white mica, epidote, chlorite, and hematite stain.

These granites are very similar to those of the Beattie \& Wilcox quarry, but they differ in that the pink is of lighter shade, and the gray has more marked mineral contrasts. Both pink and gray are attractive stones, well adapted for massive structures.

The quarry, opened before 1865 , is 900 by 700 feet and from 20 to 60 feet deep. The stripping consists of 2 to 6 feet of gravel and bowlders.

The sheets, from 8 inches to 8 feet thick, are horizontal or dip $5^{\circ}$ to $10^{\circ} \mathrm{SE}$. Joint and dike courses are shown in figure 41 . Joint set $a$ forms a heading 30 feet wide through the center of the quarry and is spaced 20 to 125 feet, with slickensided sericite-coated close joints parallel to it (specimen $\mathrm{D}$, $\mathrm{XXX}, 117$, c). Set $b$, vertical, forms the south wall and is spaced about 40 feet. Set $c$, vertical, forms a heading 50 feet wide diagonally through the quarry. The rift is horizontal and the grain scarcely perceptible. A 3-inch pegmatite dike containing much quartz $\operatorname{dips} 43^{\circ} \mathrm{N} .55^{\circ} \mathrm{W}$. and has shear zones

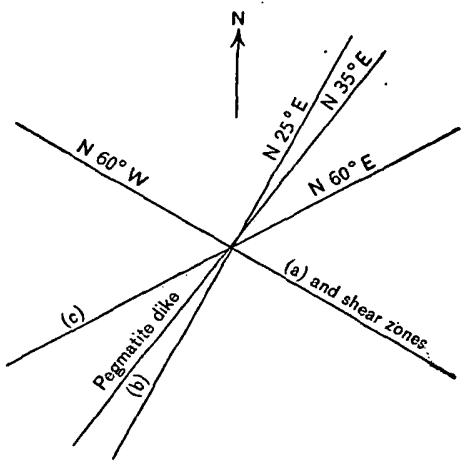

Figure 41.-Structure at Beattie quarry, Fall River, Mass.

along it with small micaceous or chloritic masses. An aplite dike is 4 inches thick. Dark segregations measure up to 3 inches across. Limonite stain is up to 6 inches thick on sheet surfaces.

The plant comprises five derricks, three hoisting engines, an air compressor (capacity 550 cubic feet of air a minute), fourteen air plug drills, two surfacers, three steam drills, and a stone crusher with $2 \frac{1}{2}, 1 \frac{1}{2}$, and $\frac{3}{4}$ inch meshes, and a daily capacity of 80 tons.

Transportation is by cart to railroad or wharf $1 \frac{1}{2}$ miles.

The product is used mostly for buildings and wharves. The waste goes into curbing, paving, and crushed stone. Specimens: Sagamore Manufacturing Co.'s mill, wharves of Fall River Iron Works, Bristol County jail, Fall River; Bristol County courthouse (except trimmings, which are of Woodbury (Vt.) granite, Taunton; Naval War College building, Newport, R. I. 
SAVOIE QUARRY.

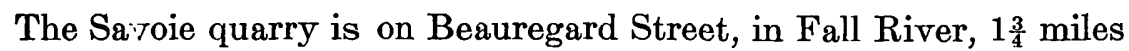
east-southeast of the steamboat wharf. Operator: H. Savoie, 85 Beauregard Street, Fall River, Mass.

The granite is a gneissoid biotite granite of light-gray shade with conspicuous black and greenish spots and of coarse inclining to medium texture, closely resembling the "gray" of the Beattie quarry described on page 250 .

The quarry, opened in 1895 , is 200 by 100 feet and 30 to 40 feet deep. The stripping consists of 5 to 13 feet of sand and bowlders.

The sheets, 2 to 6 feet thick, are horizontal. There are four sets of joints. Set $a$, vertical, strikes N. $60^{\circ} \mathrm{W}$.; forms a heading on the north wall. Set $b$, steep to vertical, strikes N. $10^{\circ}-20^{\circ} \mathrm{W}$; f forms the east and west walls and a heading 20 feet wide at the south end and is spaced 5 to 60 feet. Set, $c$ strikes NE., dips $30^{\circ} \mathrm{NW}$.; only two, 12 feet apart. Set $d$, diagonal, strikes N. $20^{\circ}$ E., dips $65^{\circ} \mathrm{S} .70^{\circ} \mathrm{E}$.; is spaced 5 to 40 feet. The rift is horizontal and grain vertical with north-south course. A dark brownish-gray aplite dike, 6 inches to 2 feet thick (specimen $\mathrm{D}, \mathrm{XXX}, 118, \mathrm{~b}$ ), strikes east-west. There is also a pinkish aplite dike 10 feet wide (specimen 118, a). Both these aplites are described on page 242. Quartz veins and shear zones strike N. $60^{\circ} \mathrm{E}$., and $\operatorname{dip} 50^{\circ} \mathrm{N}$. $30^{\circ} \mathrm{W}$. There is no "sap" away from headings.

The plant comprises three derricks, a hoisting engine, an air compressor (capacity 200 cubic feet of air a minute), four air plug drills, a steam drill, and two steam pumps.

Transportation is by cart to dock or rail, $2 \frac{1}{4}$ miles.

The product is used for buildings, curbing, and paving and its market is mostly local. Specimens: City library, Maple Street School (trimmings), Fall River.

\section{SEARS GUARRY.}

The Sears quarry is in Fall River, about $1 \frac{1}{4}$ miles east of the steamboat wharf. Operator: C. H. Sears, Fall River, Mass.

The granite is a gneissoid biotite granite of light-gray shade with conspicuous black and greenish spots and of coarse inclining to medium texture, like the "gray" of the Beattie quarry described on page 250 .

The quarry, opened in 1892 , is 125 by 75 feet and 20 feet deep. The stripping consists of 5 to 10 feet of clay and sand.

The sheets, 1 to 8 feet thick, undulate. There are two sets of joints. Set $a$, not far from east-west, forms the north wall and a heading 15 feet wide through the center of the quarry and is spaced 2 to 20 feet. Set $b$, nearly north-south, forms the west wall and is spaced 10 to 20 feet but in places crosses one sheet only. The rift is horizontal and 
the grain, vertical, north-south, but scarcely perceptible. There is little "sap" away from headings.

The plant comprises a derrick, a hoisting engine, a small air compressor, two air plug drills, a steam drill, and a steam pump.

Transportation is by cart.

The product is used for local buildings. Specimen: Lower story of Textile School, Fall River.

\section{ROSS QUARRY.}

The Ross quarry is at the head of Barlow Street, near Watuppa Pond, in Fall River, 23 miles about southeast of the steamboat wharf. (See map of Fall River quadrangle, U. S. Geol. Survey.) Operator: George Ross, 69 Pitman Street, Fall River, Mass.

The granite (specimen D, XXX, 119, a), "Fall River, Barlow Street," is a gneissoid biotite granite of medium bluish-gray color and of medium texture, with feldspars up to 0.3 inch and mica up to 0.1 inch. Its constituents, in descending order of abundance, are pinkish cloudy microperthite (potash feldspar (orthoclase and microcline), minutely intergrown with soda feldspar); clear colorless quartz, granulated, with particles nearly all under 0.5 millimeter; clear colorless to pale-greenish soda feldspar (albite), micasized and epidotized; and biotite (black mica), some of it chloritized, associated with epidote and a little muscovite or bleached biotite. Accessory: Garnet. Secondary: Muscovite in stringers, also a white mica in the albite, epidote, carbonate, and chlorite. It shows no effervescence with hydrochloric-acid test.

As will be noticed from the description, this stone differs from the other Fall River gray granites in the absence of the large black micas. The second feldspar here is pure albite. The mineral contrasts are feeble.

The quarry, opened before 1901, is 125 feet square and 30 feet deep. The stripping consists of 5 to 10 feet of sand and bowlders.

The sheets, 1 to 5 feet thick, on the east side, are lacking on the west side. There is only one joint, striking east-west and forming the south wall. The upper sheets are badly discolored.

The plant comprises three derricks, a hoisting engine, a small air compressor, two air plug drills, a steam drill, and a steam pump.

Transportation is by cart.

The product is curbing, crossing flags, and paving stones for local use.

\section{NEW BEDFORD.}

\section{SULIIVAN QUARRIES.}

The Sullivan quarries are near Rockdale in the township of New Bedford, 2 miles northwest of the city. (See map of New Bedford quadrangle, U. S. Geol. Survey, and Pl. V.) Operators: John B. Sullivan \& Son, New Bedford, Mass. 
The granite (specimens $\mathrm{D}, \mathrm{XXX}, 121$, a, pinkish, and $\mathrm{b}$, less pinkish), "New Bedford," is a biotite-muscovite granite gneiss of light pinkish-gray color and of slightly gneissoid, coarse inclining to medium texture, with feldspars up to 0.5 inch and mica up to 0.1 inch. Its constituents, in descending order of abundance, are lightpinkish potash feldspar (microcline), some of it slightly kaolinized; medium smoky quartz with cavities and black particles in paral'el sheets; milky soda-lime feldspar (oligoclase-albite); biotite (black mica), some of it chloritized; and muscovite (white mica). Accessory: Garnet, magnetite, fluorite, apatite, and zircon. Secondary: Kaolin, epidote, chlorite, and limonite. No carbonate or pyrite detected. It shows no effervescence with hydrochloric-acid test.

This is an attractive and substantial building stone. Its mineral contrasts are a little more marked than those of the Dartmouth granite. The absence or scarcity of pyrite and carbonate are in its favor.

The quarries comprise two openings. The main one, begun about 1860 , is 600 by 150 feet and from 50 to 75 feet deep. The other, about 300 feet farther south, formerly known as the Denault quarry, is about 250 by 150 feet and from 50 to 70 feet deep. Dike, joint, and grain courses are shown in figure 39 (p. 244). The sheets in the main quarry are from 10 to 25 feet thick, but for a space of 5 or 6 feet on either side of the dikes there are sheets from 3 to 18 inches thick, which were evidently formed after the dikes and largely in consequence of them. There are two sets of joints. Set $a$, coated with epidote, is vertical and spaced 50 feet. Set $b$, confined to the Denault quarry, dips $55^{\circ} \mathrm{E}$., is spaced 2 to 30 feet, with a heading at east wall and another 10 to 18 feet wide near it. The rift is horizontal. The dikes have been described on page 244. There is one each on the north, south, and west walls, through the center, and another of pegmatite near the west wall. The amount of rusty stain is small.

The plant comprises seven derricks, five hoisting engines, three air compressors (capacity 270 cubic feet of air a minute), twenty air plug drills, two surfacers, six steam drills, three steam pumps, and a stone crusher with adjustable screens and a daily capacity of 100 to 115 tons.

Transportation is by cart to New Bedford, 2 or 3 miles.

The product is used for local buildings and streets. Specimens: Armory, public library (90 per cent, the rest being from Fall River quarries), St. James and St. John Roman Catholic churches, and trimmings to most of the cotton mills, New Bedford. 


\section{ESSEX COUNTY.}

LYNNFIELD.

\section{ROBIN ROCK QUARRY.}

The Robin Rock quarry is in Lynnfield Township, four-fifths of a mile south-southeast of South Lynnfield station. (See map of Lawrence quadrangle, U. S. Geol. Survey.) Operator, Arthur L. Kallenberg, Lynnfield, Mass.

The granite (specimen D, XXX, 127, a), "Robin Rock green," is a hornblende-augite granite of ve ry dark greenish-gray color andof coarse even-grained texture, with feldspars up to 0.6 inch and black silicates up to 0.4 inch. Its constituents, in descending order of abundance, are dark-blue or greenish-gray microperthite (potash feldspar (orthoclase), minutely intergrown with soda feldspar (albite) and kaolinized) ; very dark, slightly greenish smoky quartz, with cavities in sheets intersecting at right angles; black (under the microscope greenish) hornblende with inclusions of allanite; very little separate soda feldspar (albite); and black (under the microscope greenish) augite. Accessory: Magnetite, allanite, pyrite, zircon, and a little biotite. Secondary: Kaolin and limonite stain. It shows no effervescence with hydrochloric-acid test.

Another variety (specimen D, XXX, 127, b), "Robin Rock gray," is also a hornblende-augite granite but of dark-gray shade, speckled with black, and of coarse even-grained texture, with feldspars up to 0.7 inch and black silicates up to 0.3 inch. Its constituents appear to be the same as the other variety, but, as shown by effervescence with acid test, carbonate is present. The microperthite is dark gray in the hand specimen but shows some limonite-stained faces. Augite is intergrown with hornblende or passing into it. Apatite appears among the accessory minerals and zircon is rather plentiful. This stone probably becomes somewhat greenish on continued exposure.

This stone appears well when fine pointed. The scientific interest of green granites has been noted on page 246 .

There are several openings, some of which are a century old. The one now worked is triangular in area, 75 feet on a side and 5 to 25 feet deep. The stripping is 1 or 2 feet of loam.

The sheets, from 18 inches to 6 feet thick, dip $10^{\circ} \mathrm{E}$. There is only one set of joints, vertical, with N. $80^{\circ} \mathrm{W}$. strike, spaced 3 to 12 feet, with a heading 15 feet wide on the north side. The rift is vertical, with east-west course, and the grain vertical, north-south. "Knots" measure up to 6 inches. The stain on sheet surfaces is yellowish for an inch, then for 2 inches the stone is pale.

The plant comprises five hand derricks.

Transportation is by cart to Wakefield and Reading, 4 to 6 miles.

The product is used for buildings, foundations, sills, steps, and curbing. 
PEABODY.

\section{LINEHAN QUARRY.}

The Linehan quarry is in Peabody Township, on a knoll one-fourth of a mile east of Bartholomew Pond, about 3 miles west-southwest of Peabody. (See map of Salem quadrangle, U. S. Geol. Survey, and Pl. V.) Operator: James C. Linehan, 18 Foster Street, Peabody, Mass.

The granite (specimen D, XXX, 128, a), "Peabody green," is a hornblende-augite granite of very dark olive greenish-gray color and of even-grained coarse testure, with feldspars up to 0.7 inch and black silicates up to 0.2 inch. Its constituents, in descending order of abundance, are dark olive greenish-gray microperthite (potash feldspar (orthoclase), minutely intergrown with plagioclase, probably soda feldspar, kaolinized and with crush borders); very dark greenish smoky quartz, with cavities in sheets intersecting, some at right angles, and with cracks filled with limonite stain; green hornblende; and augite intergrown with or passing into the hornblende. Accessory: Magnetite, allanite, rather plentiful zircon, and apatite needles. Secondary: Kaolin, limonite stain, and carbonate. It shows slight effervescence with hydrochloric-acid test.

This granite differs from the green of the Robin Rock quarry (p. 255) only in its more yellowish tinge. When first quarried it is grayish, but within a week it becomes yellowish green. (See p. 246.)

The quarry, opened in 1900, is 250 feet east and west by 80 and 100 feet across and 20 to 40 feet deep.

The sheets, from 8 to 16 feet thick, are lenticular and horizontal. There are three sets of joints. Set $a$, vertical, strikes N. $15^{\circ} \mathrm{E}$.; on east and west walls only, 250 feet apart. Set $b$, "rift joints" diagonal strikes $\mathrm{N} .70^{\circ} \mathrm{E}$., dips $65^{\circ} \mathrm{S} .20^{\circ} \mathrm{E}$., is coated black with hornblende, ${ }^{1}$ also with calcite up to 0.12 inch thick, and is spaced 30 to 60 feet. The rift, which is marked, is parallel to set $b$, the grain is at right angles to it, and the hardway horizontal. Dark-gray knots are from half an inch to 12 inches across. The stain forms a dark-brown surface on the sheets with an inch of pale granite below it; in places, however, the brown part is an inch thick and the pale granite 2 inches. The joints are also discolored in this way.

The plant comprises three hand derricks, a hoisting engine, a steam drill, and a steam pump.

Transportation is by cart, an average of 3 miles.

The product is used for street work and trimmings. Specimen: Trimmings on addition to Mercantile Bank, Salem, Mass.

1 These black-coated joints are analogous to those of the Quincy quarries, where, however, the mineral is the soda hornblende, riebeckite. They signify metamorphism after the jointing. See Bull. U. S. Geol. Survey No. 354,1908 , pp. 60,61 . 


\section{CARON QUARRY.}

The Caron quarry is in Peabody Township, about one-fourth mile south-southeast of the town farm on Lynnfield Street. (See map of Salem quadrangle, U. S. Geol. Survey.) Operator: M. Caron, Perkin Street, Salem, Mass.

The granite, "Peabody green," is a hornblende-augite granite of very dark olive greenish gray color and of even-grained coarse texture like that of the Linehan quarry, described on page 256.

The quarry, opened in 1898 , is 75 by 30 feet and from 10 to 30 feet deep. The stripping is up to 6 inches thick.

This is a "bowlder quarry" yielding blocks 18 feet thick. There are two sets of joints. Set $a$ strikes N. $77^{\circ}$ E., dips $60^{\circ} \mathrm{S} .13^{\circ} \mathrm{E}$., is spaced 10 to 20 feet. Set $b$ strikes N. $40^{\circ}$ E., dips $50^{\circ}$ N. $50^{\circ} \mathrm{W}$. and is spaced over 30 feet. The rift is parallel to set $a$ and the grain dips $70^{\circ}$ about west. The "sap" is up to 3 inches thick on masses below the surface, half of it being brown.

The plant comprises a hand derrick and a steam drill.

Transportation is by cart to Lynn, Salem, Beverly, and other places.

The product is used for trimmings and curbing. Specimens: Trimmings on hotel at corner of Mill and Washington streets, and on store at corner of Derby and Dinell streets, Salem.

\section{DEN QUARRY.}

The Den quarry is on the Peabody and Lynn town line, about $2 \frac{3}{4}$ miles north-northwest of Lynn station. (See map of Boston Bay quadrangle, U. S. Geol. Survey.) Operator: C. E. Mudge, Lynnfield Street, Lynn, Mass.

The granite (specimens D, XXX, 126, a, b), "Peabody green," is a hornblende-augite granite of dark to very dark olive greenish gray color. When first quarried the feldspars are less greenish and lighter and the general color corresponds, but this soon changes. Its texture is even grained coarse, with feldspars up to 0.7 inch and black silicates up to 0.4 inch. Its constituents, in descending order of abundance, are medium but soon becoming dark greenish-gray microperthite (potash feldspar (orthoclase), minutely intergrown with soda feldspar (albite), much kaolinized, with crush borders and with cracks filled with limonite stain); very dark yellow-greenish smoky quartz, with cavities in sheets, some intersecting at right angles, and with cracks parallel to them filled with limonite stain; black hornblende (green in section), with inclusions of allanite; and black augite (green in section), intergrown with or passing into the hornblende, also with inclusions of allanite. Accessory: Magnetite, allanite, zircon, apatite, and very little biotite. Secondary: Limonite stain proceeding from the allanite and augite and following the boundaries of particles and cracks, kaolin, a brown and also a blue hornblende (probably $94174^{\circ}-$ Bull. $470-11+17$ 
riebeckite) in fibrous crystals growing out of the augite surfaces into quartz and feldspars, and carbonate. It shows very slight effervescence with hydrochloric-acid test.

This stone is reported to take a good polish, which might be expected from its lack of mica. (See, for discussion of green granites, p. 246.)

The quarry, opened about 1905 , is about 100 feet square and 20 to 60 feet deep.

The sheets, 16 to over 30 feet thick, dip $20^{\circ} \mathrm{S}$. $55^{\circ} \mathrm{E}$. There are four sets of joints. Set $a$, discontinuous, strikes N. $5^{\circ} \mathrm{E}$., dips $75^{\circ} \mathrm{E}$., forms a heading on east wall, is spaced 30 to 40 feet. Set $b$, vertical, strikes east-west; forms a heading 100 feet wide on east wall, is spaced 25 to 40 feet. Set $c$ strikes N. $40^{\circ}$ W., dips $47^{\circ}$ S. $50^{\circ} \mathrm{W}$.; one only. Set $d$, vertical, strikes N. $30^{\circ} \mathrm{W}$.; one only. The rift dips steeply $\mathrm{S} .60^{\circ} \mathrm{W}$. and the grain, which is almost as pronounced as the rift, is horizontal. Very dark gray segregations (knots) are up to 0.5 inch, exceptionally 2 feet, across. A thin section of one of these knots (specimen D, XXX, 126, d) shows a groundmass of particles of microperthite and plagioclase (probably albite) from 0.1 to 0.3 millimeter in diameter, with thickly disseminated particles of augite from 0.02 to 0.37 millimeter, and minute grains of magnetite. At the edge is a large porphyritic microperthite, a crystal of zircon, and a particle of augite associated with a blue hornblende, biotite, magnetite, and zircon.

The feldspars on the sheet surfaces are generally much kaolinized. The rusty stain (specimen $\mathrm{D}, \mathrm{XXX}, 126, \mathrm{c}$ ) measures up to an inch in thickness and the pale-green band below it from 2 to 4 inches. A top sheet, 12 feet thick and 100 by 40 feet in area, is all discolored.

The plant comprises two hand derricks.

Transportation is by cart, mostly to Lynn, nearly 3 miles.

The product is used for base courses, steps, curbing, crossings, caps, and paving. The rusty faces are used for base courses. Specimens: Starr Parsons monument in Pine Grove Cemetery, and sap-faced base course of dwelling at corner of Wave and Ocean streets, Lynn.

\section{OTHER QUARRIES.}

Several other quarries of this granite west and southwest of Peabody in that township, which were not operated in 1910, were not visited.

\section{HAMPDEN COUNTY.}

MONSON.

FLYNT QUARRIES.

The Flynt quarries are in Monson Township on the southwest side of Bunyan Mountain, $1 \frac{1}{4}$ miles north-northwest of Monson station. (See map of Palmer quadrangle, U. S. Geol. Survey, and Pl. V.) Operator: William N. Flynt Granite Co., Monson, Mass. 
The granite (specimens D, XXX, 90, a, b, c), "Monson" (darker variety, used for faces of buildings), is a biotite-quartz monzonite gneiss of dark to very dark gray shade and fine to very fine elongated (unplicated) gneissic texture, with feldspars and mica up to 0.2 inch, but mostly under 0.1 inch. Its constituents, in descending order of abundance, are clear colorless quartz with cavities; bluish translucent potash feldspar (microcline and orthoclase); milk-white sodalime feldspar (andesine); and biotite (black mica). Accessory: Magnetite (fifth in order of abundance), garnet, zircon, apatite, and allanite. Secondary: Epidote (sixth in order of abundance) and chlorite. It shows no effervescence with hydrochloric-acid test. No pyrite is visible on the polished face.

A light to medium gray variety (specimen 90, c) with fine bands of dark gray has the same composition as the rock described above, but less biotite. This stock is used for curbing, foundations, etc.

The Monson gneiss is now regarded by B. K. Emerson as of igneous origin and probably of Carboniferous age.

The following analysis of it was made by W. F. Hillebrand: ${ }^{1}$

Analysis of biotite-quartz monzonite gneiss from Flynt quarry, Monson, Mass.

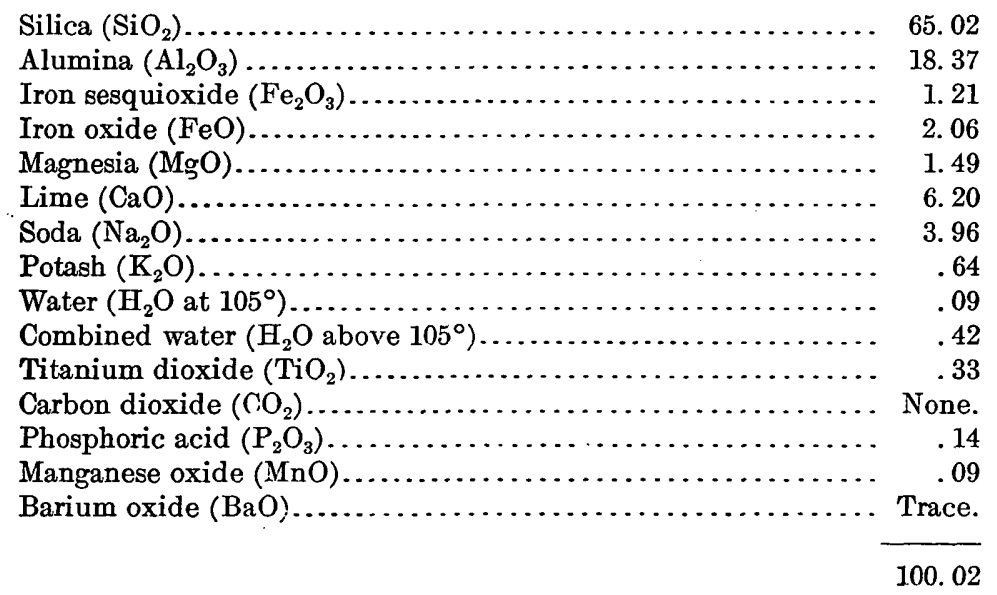

Merrill ${ }^{2}$ states that a test of this gneiss showed a crushing strength of 15,390 pounds per square inch with the pressure applied at right angles to the foliation, and 12,720 pounds with the pressure applied in the direction of the foliation.

The fine and even foliation of this gneiss renders it more suitable for some purposes and less for others than a true granite. The absence of pyrite in its composition is much in its favor as a building stone. Its foliation prevents its taking a high polish. 
The first opening was made in 1824 by United States agents for the construction of the armory at Springfield, Mass. The quarry now in operation is about 350 by 150 feet and from 20 to 30 feet deep. The stripping consists of 2 feet of sand.

The sheets, 6 inches to 10 feet thick, but mostly 2 to 5 feet, dip $5^{\circ}$ to $20^{\circ} \mathrm{W}$. The only joints are parallel to the foliation and are spaced 10, 50, and 90 feet. The gneiss foliation strikes N. $10^{\circ} \mathrm{E}$. and dips $75^{\circ} \mathrm{N} .80^{\circ} \mathrm{W}$. The rock is of light, medium, and dark gray shades in alternating bands of very different widths. Some are not over 0.25 inch wide; others 2 or 3 feet. These bands are free from plications, but one was found doubled over on itself vertically for the space of a foot. Each band as seen on the sheet surface also varies greatly in width. Some foliation faces are chloritic. The rift corresponds to the foliation and the grain is horizontal. A few pegmatite bands up to 3 inches thick occur. There is no rusty stain.

The Monson quarries have long been referred to as affording evidence of compressive strain, ${ }^{1}$ but although the rock is still under a north-south strain, fracturing attended with explosive sounds no longer occurs. ${ }^{2}$

The plant comprises eight derricks, five hoisting engines, a locomotive, an air compressor (capacity 550 cubic feet of air a minute), forty air plug drills, forty air hand tools, five surfacers, a polisher, a steam pump, and a stone crusher with screens of $2 \frac{1}{2}, 1 \frac{1}{4}$, and $\frac{3}{4}$ inch meshes.

Transportation is by a $1 \frac{1}{4}$-mile siding from the Central Vermont Railway at Monson.

The product is used for buildings, bridges, and monuments; the seconds for curbing, foundations, and crushed stone for concrete. Specimens: Horatio Lyon Library, Monson; Walker Hall, Amherst College; Church of St. Francis Xavier on Sixteenth Street, and Isabella Home on One hundred and nineteenth Street, New York; Munn Monument, Woodlawn Cemetery, New York; Roman Catholic Church and rectory, West New Rochelle, N. Y.; residence of Charles La Dow, Thurlow Terrace, Albany, N. Y.; Congregational Church and Doane buildings, Rockville, Conn.; fountain at Weatogue, Conn.; Hall Memorial Chapel, Watertown, Conn.; high school, East Orange, N. J.; Park Avenue Methodist Church, Chicago.

1 See Niles, W. H., Some interesting phenomena observed in quarrying: Proc. Boston Soc. Nat. Hist., vol. 14, 1872, pp. 80-87; vol. 16, 1874, pp. 41-43; also Emerson, B. K., Geology of Old Hampshire County, Mass.; Mon. U. S. Geol. Survey, vol. 29, 1898, pp. 64, 65.

2 See, on this subject in general, Bull. U. S. Geol. Survey No. 354, 1908, p. 28; Bull. 404, 1909, p. 17; also, on similar phenomena in the granite quarries of Quenast in Belgium; Hankar-Urban, A., Note sur des mouvements spontanés des roches dans les carrières: Bull. Soc. Belge géol., pal., et hydrol., vol. 19, Brussels, 1906, pp. 527-540, and other papers by same author in vol. 21, 1907, and vol. 23, 1909. 
HAMPSHURE COUNTY.

PELHAM.

WARD QUARRY.

The Ward quarry is in Pelham Township, 2 miles northeast of West Pelham and about 4 miles east-northeast of Amherst. (See map of Belchertown quadrangle, U. S. Geol. Survey, and Pl. V.) Operator: E. P. Bartlett, R. F. D., West Pelham, Mass.

The granite (specimens D, XXX, 91, a, b, c), "Pelham gneiss," is a biotite granite gneiss of very fine elongated (unplicated) gneissic texture and of general dark bluish-gray shade, with feldspars and mica under 0.1 inch. It is finely banded, the bands being mostly not over 0.04 inch wide and of very dark gray alternating with white. There are fine-grained white bands without black mica (specimen c). There are also lenses of quartz and feldspar up to 0.3 inch wide and several inches long, containing black mica crystals up to 0.3 inch in diameter, lying transverse to the foliation (specimen b). - Its constituents, in descending order of abundance, are clear to translucent bluish potash feldspar (microcline and orthoclase); very pale smoky quartz; biotite (black mica) with a little muscovite; and very little milk-white plagioclase feldspar, kaolinized. Accessory: Magnetite, titanite, zircon, allanite, and apatite. Secondary: Kaolin, epidote, carbonate, and chlorite. It shows no effervescence with hydrochloric-acid test.

An analysis of this gneiss made by George Steiger, a chemist of this Survey, follows:

Analysis of biotite granite gneiss from Pelham, Mass. ${ }^{1}$

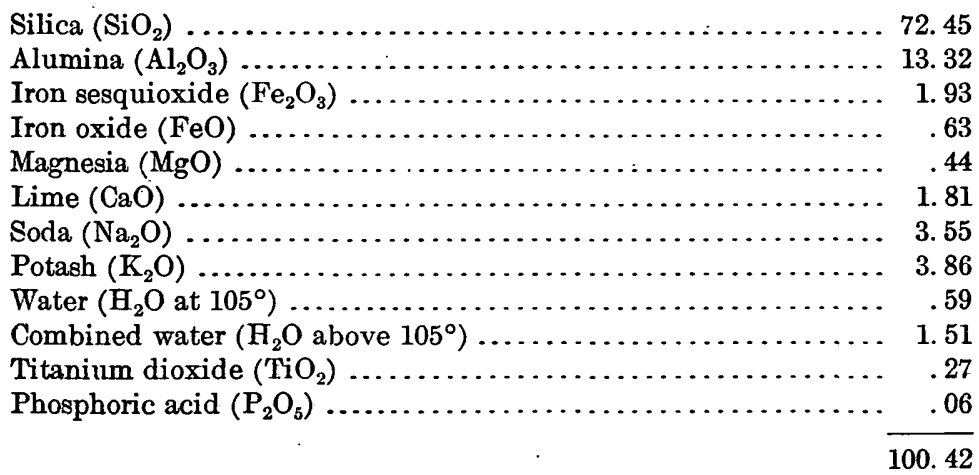

In comparing this analysis with that of the Monson gneiss (p. 259), it will be noticed that this has higher percentages of silica and potash and lower of alumina, iron oxides, magnesia, and lime. The microscopic descriptions of the two rocks show that the Monson gneiss contains much more soda-lime feldspar than the Pelham stone. 
B. K. Emerson now regards the Pelham gneiss as of igneous origin and probably of Carboniferous age.

The Pelham gneiss in appearance resembles that of Monson and its economic uses and value are similar. The shade of the Pelham stone is a trifle lighter than the best dark of the Monson quarry.

The quarry, opened before 1862 and now worked irregularly, measures about 200 feet in a northwest direction and has a working face 25 feet high on the northeast. The stripping consists of 5 to 10 feet of sand.

The sheets, from 6 inches to 2 feet thick, are parallel to the gneiss foliation, which strikes N. $80^{\circ} \mathrm{W}$. and dips in undulations $5^{\circ}$ to $13^{\circ} \mathrm{N}$. $10^{\circ} \mathrm{E}$. The sheet surfaces are slickensided, with striæ striking $\mathrm{N}$. $10^{\circ} \mathrm{E}$. There are no joints. The rift is parallel to the foliation and the grain probably vertical, with N. $10^{\circ}$ E. course. Pegmatite dikes of light feldspar, smoky quartz, and biotite measure up to an inch thick, dipping $50^{\circ}$ to $60^{\circ}$ about north. Lenses of smoky quartz measuring up to 30 feet long and to 6 inches thick lie in the foliation, and porphyritic feldspar lenses up to 3 by 2 inches are strung along in the foliation, forming in places, with biotite and quartz, pegmatitic bands up to 2 inches thick. One such lens contains black hornblende masses 2 inches by 1 inch.

The plant comprises two hand derricks.

Transportation is by cart to Amherst, about 4 miles.

The product is used for local buildings. Specimens: Old gymnasium and basement story of new geological and zoological building at Amherst College.

\section{MTDDLESEX COUNTY.}

ACTON.

HARRIS QUARRY.

The Harris quarry is in Acton Township, one-half mile north-northwest of North Acton station. (See map of Lowell quadrangle, U. S. Geol. Survey, and Pl. V.) Operator: North Acton Granite Co., North Acton, Mass.

The granite (specimens D, XXX, 111, a, b), "Acton," is a biotitemuscovite-quartz monzonite gneiss of light bluish-gray color and of fine gneissic texture, with feldspars under 0.2 inch, exceptionally up to 0.3 inch, and mica up to 0.1 inch. Its constituents, in descending order of abunàance, are milk-white soda-lime feldspar (oligoclase), some of it much kaolinized, some minutely intergrown with quartz (vermicular structure); in nearly equal amount, clear to translucent bluish potash feldspar (microcline and probably orthoclase); clear colorless quartz, strained, with rutile needles and some cavities; biotite (black mica), some of it chloritized; and muscovite (white mica). Accessory: Magnetite, rather plentiful, apatite, rutile, and zircon. 
Secondary: Kaolin, epidote, carbonate, and chlorite. It effervesces with hydrochloric-acid test.

This is a bright stone of sufficient coarseness to show the mineral contrasts, the colors being black and white.

The quarry, opened in 1885 , is 200 by 100 feet and from 10 to 35 feet deep. The stripping, up to 10 feet thick, is of sand and bowlders.

There are traces of sheets from 6 inches to 3 feet thick, but blocks 12 feet thick can be obtained. This is a "bowlder quarry." There are two sets of joints. Set $a$ strikes N. $75^{\circ}$ E., dips $75^{\circ} \mathrm{S} .15^{\circ} \mathrm{E}$; slickensided and coated with epidote, one only, forming the north wall. Set $b$ strikes N. $35^{\circ} \mathrm{W}$., dips $45^{\circ} \mathrm{S} .55^{\circ} \mathrm{W}$. to $90^{\circ}$; is spaced 5 to 50 feet. The rift is about horizontal and the grain vertical with N. $55^{\circ}$ E. course. Pegmatite dikes up to 5 inches thick have a N. $30^{\circ}$ W. course. Rusty stain is up to a foot thick on the outer masses.

The plant comprises two derricks, a hoisting engine, a "bull-wheel engine" for turning a 15-ton derrick, an air compressor (capacity, $17 \frac{1}{2}$ horsepower), two air plug drills, three air hand tools, a surfacer, and a centrifugal pump.

Transportation is by cart to North Acton station, half a mile.

The product is used for buildings, monuments, and curbing, mostly in eastern Massachusetts. Specimens: James Wetherbee monument, Woodlawn Cemetery, Acton; Samuel Guilford monument, Mount Hope Cemetery, and Dunlop monument, Sleepy Hollow Cemetery, West Acton.

\section{MCCARTHY QUARRY.}

The McCarthy quarry is in Acton Township, about half a mile northwest of North Acton station, at the top of a small knoll. (See map of Lowell quadrangle, U.S. Geol. Survey, and Pl. V.) Operator: Thomas McCarthy, North Acton, Mass.

The granite (specimen D, XXX, 112, a), "Acton, finer grained," is a biotite-muscovite-quartz monzonite of light to medium bluishgray color and of fine to very fine, obscurely gneissoid texture, with feldspars under 0.2 inch and mica up to 0.1 inch, but mostly under 0.05 inch. Its constituents, in descending order of abundance, are translucent to milk-white soda-lime feldspar (oligoclase-andesine), slightly kaolinized; in nearly equal amount, clear bluish potash feldspar (microcline and probably orthoclase); clear colorless quartz, strained, in places granulated and with cavities; biotite (black mica); and muscovite (white mica), also stringers of secondary fibrous muscovite. Accessory: Magnetite, apatite, and zircon. Secondary: Epidote, carbonate, muscovite, and kaolin. It shows no effervescence with hydrochloric-acid test.

This is a fine-grained stone without mineral contrasts and is suitable for fine work. 
The quarry, opened in 1890 , is 150 by 80 feet and 20 feet deep. The stripping consists of 3 feet of loam and gravel.

The sheets, from 6 to 16 inches thick, are horizontal or dip $10^{\circ} \mathrm{NE}$. There are no joints. The rift is horizontal and the grain vertical with northeast course. A pegmatite dike 2 feet thick on the northwest side is parallel to the grain. On the southeast, northwest, and southwest sides the granite is in contact with a quartz-mica diorite which is described on page 242. On the northwest side, 6 feet from the contact, there is an inclusion of this diorite gneiss. There is no rusty stain.

The plant consists of a horse derrick. Drainage is by siphon.

Transportation is by cart to North Acton station about threefourths of a mile.

The product is used for buildings, monuments, and curbing. Specimens: Schoolhouse back of mill on Maynard estate, Maynard, Mass.

\section{GROTON.}

\section{RAFFERTY QUARRY.}

The Rafferty quarry is in Groton Township, 4 miles east-southeast of Groton village and $1 \frac{1}{2}$ miles northwest of West Graniteville station. (See maps of Groton and Lowell quadrangles, U. S. Geol. Survey, and Pl. V.) Operator: Thomas Rafferty, Graniteville, Mass.

The granite (specimens D, XXX, 100, c, d), "Groton," is a muscovite-biotite granite gneiss of light to medium gray shade and of medium inclining to coarse gneissic, slightly porphyritic texture, with feldspars up to 0.5 inch and mica up to 0.1 inch. Its constituents appear to be identical with those of specimens $93, \mathrm{a}, \mathrm{b}$, c, from the H.E. Fletcher quarry on Oak Hill, in Westford (p.266). It effervesces with hydrochloric-acid test.

This stone, like the granite gneisses of Westford, is devoid of mineral contrasts. It is well adapted for base courses and all work requiring much greater transverse strength in one direction than in the other and for curbing.

The quarry, begun in a small way in 1860 , and but recently reopened is 50 feet square, its west side being 30 feet higher than the east side. But one sheet has been removed. The stripping consists of 2 feet of soil.

The sheets, 2 to 6 feet thick, dip $20^{\circ} \mathrm{N} .35^{\circ} \mathrm{E}$. One joint at the west side strikes $\mathrm{N} .75^{\circ} \mathrm{E}$. and dips $75^{\circ} \mathrm{S} .15^{\circ} \mathrm{E}$. The gneiss foliation is vertical, with $\mathrm{N} .30^{\circ} \mathrm{E}$. strike. The rift is horizontal and the grain corresponds to the foliation, the face of which is more micaceous than the rift.face. A 30-foot inclusion of porphyritic biotite granite gneiss (described on p. 242) and two other smaller ones lie in the eastern 
part of the quarry. The axis of the long inclusion points N. $5^{\circ} \mathrm{E} . \quad \mathrm{A}$ pegmatite dike up to 6 inches thick crosses the gneiss and the inclusion, as do also small dikes of aplite gneiss with oligoclase-albite. No stain appears below the surface sheet.

The plant consists of three hand derricks.

Transportation is by cart to a siding near West Graniteville station, $1 \frac{1}{2}$ miles.

The product thus far has been used for curbing.

SHAKER QUARRY.

The Shaker quarry is in Groton Township, on an 80-foot hillock three-fourths of a mile north-northwest of Littleton station and 4 miles southeast of Groton village. (See map of Groton quadrangle, U. S. Geol. Survey.) Operator: H. N. Fletcher, Graniteville, Mass.

The granite (specimen D, XXX, 106, a), "Groton," is a muscovitebiotite granite gneiss of medium bluish-gray color and slightly porphyritic, medium inclining to fine gneissic texture, with feldspars up to 0.3 inch. Its constituents, in descending order of abundance, are bluish translucent potash feldspar (microcline and orthoclase); light smoky quartz with rutile needles and cavities, granulated, with particles under 0.37 millimeter; milk-white soda-lime feldspar (near oligoclase-albite), kaolinized and micasized; muscovite (white mica), and biotite (black mica), some of it chloritized. There are also some fibrous muscovite stringers. Accessory: Garnet and apatite. Secondary: Kaolin, two white micas, epidote, and chlorite. It shows no effervescence with hydrochloric-acid test.

This stone is like the other gneisses of Groton and Westford, but is more bluish and of uniform shade, without mineral contrasts.

The quarry, temporarily idle in 1910, is of triangular form, 100 feet on a side and from 10 to 25 feet deep.

The sheets, from 6 inches to 3 feet thick, undulate。

The product has been used for buildings.

WESTFORD.

The 13 active quarries of Westford are in two groups. One is on Oak Hill, an irregular mass of knolls rising to a height of 200 feet above Merrimac River, in the northern part of the township. All but one of this group have their granite landing at Woods Corners (Slab City), on both Merrimac River and a siding of the Boston \& Maine Railroad, 4 miles roughly west from Lowell. The other group is on Snake Meadow Hill, from 100 to 160 feet above the nearest railroads, in the southwestern part of the township. This group has its outlet at the Graniteville and West Graniteville stations, not a mile away and about 9 miles west-southwest of Lowell. (See Pl. V.) 


\section{H. E. FLETCHER QUARRY.}

The H. E. Fletcher quarry is on the southeastern part of Oak Hill, in Westford Township, $1 \frac{1}{4}$ miles northwest of West Chelmsford station. (See map of Lowell quadrangle, U. S. Geol. Survey.) Operator: H. E. Fletcher Co., West Chelmsford, Mass.

The granite (specimens D, XXX, 93, a, b, c), "Oak Hill," is a muscovite-biotite granite gneiss of very light, slightly bluish gray shade on the rift face but light gray on the grain face, and of medium, slightly porphyritic texture, with feldspars up to 0.3 inch and micas up to 0.2 inch. Its constituents, in descending order of abundance, are bluish translucent potash feldspar (microcline and othoclase), slightly kaolinized; milk-white soda-lime feldspar (oligoclase), much kaolinized and with some white mica; clear colorless quartz, finely granulated, with particles to 0.5 millimeter, but mostly under 0.37 millimeter, and with rutile needles and some cavities; muscovite (white mica); biotite (black mica) some of it chloritized; and stringers of fibrous muscovite. Accessory: Apatite. Secondary: Kaolin, white micas, carbonate, epidote, and chlorite. It shows very slight effervescence with hydrochloric-acid test.

This gneiss is well adapted for base courses and all work requiring much greater transverse strength in one direction than in another. It is devoid of mineral contrasts. The absence or great scarcity of pyrite and magnetite is favorable to the durability of its shade.

The quarry, opened about 1880, measures about 700 feet in a northeast direction by 500 feet across and from 30 to 40 feet in depth. The stripping consists of 5 to 10 feet of sand and bowlders.

The sheets, 8 inches to 12 feet thick, undulate horizontally. There are three sets of joints. Set $a$ strikes N. $30^{\circ}-40^{\circ}$ E., curving to N. $55^{\circ}$ E., dips $70^{\circ} \mathrm{N}$. $55^{\circ} \mathrm{W}$. to $90^{\circ}$, and forms a heading on the southeast wall. Set $b$ strikes N. $30^{\circ}$ W., dips $60^{\circ}$ N. $60^{\circ}$ E., on southwest wall. Set $c$ strikes N. $50^{\circ}$ E., dips $65^{\circ}$ N. $40^{\circ}$ W., and is spaced 300 feet and over. The gneiss foliation strikes N. $30^{\circ}-40^{\circ} \mathrm{E}$. and dips $65^{\circ} \mathrm{N} .55^{\circ} \mathrm{W}$., but appears to be crossed by a shear zone dipping $65^{\circ}$ about southeast. The relations of these foliations are obscure. The rift is horizontal, and the grain, vertical with N. $40^{\circ}$ E. course, is parallel to the foliation, which shows more mica than the rift face. An aplite dike, $1 \frac{1}{2}$ inches thick, bordered with half an inch of pegmatite on either side, has an east-west course. Pegmatite dikes are up to 8 inches thick. Where the granite is pegmatitic the mica is in crystals up to 0.4 inch across. (Specimen D, XXX, 93, c.) The amount of limonite stain is insignificant. Mr. Fletcher states that he finds a compressive strain which relieves itself by an expansion amounting to an inch in 100 feet.

The plant comprises 14 derricks, some of them lifting 15 tons, 12 hoisting engines, a locomotive, a locomotive crane, 2 air compressors 
(joint capacity, 2,000 cubic feet of air a minute), 60 air plug drills, 65 air hand tools, 8 surfacers, 2 steam drills, a stone saw for steel shot (capacity 100 square feet an hour), a steam pump, 2 stone crushers with $2,1 \frac{1}{4}$, and $\frac{1}{2}$-inch meshes and a joint daily capacity of 400 tons. Three 10 horsepower steam engines supply power for the shops, and electric power amounting to 250 horsepower is obtained for the quarry from Lowell.

Transportation is by siding to Brookside station, on the Boston \& Maine Railroad, $1 \frac{1}{2}$ miles.

The fine stock produced is used for buildings and the coarse pegmatitic rock for bridges, paving, curbing; the waste is crushed for concrete. Specimens: First National Bank, Boston; granite for the Frick Mansion at Prides Crossing, near Beverly, Mass.; base course and steps of courthouse, Lowell; soldiers' monument, Plaistow, N. H.; 20 stories (sixth to twenty-fifth) of Bankers' Trust Co. building, New York; steps, base course, and approaches of post office and United States courthouse, New Orleans; piers for Boston Elevated Railroad to Cambridge.

\section{OAK HILL QUARRY.}

The Oak Hill quarry is near the north end of Oak Hill, in Westford Township, 6 miles west of Lowell. (See map of Lowell quadrangle, U. S. Geol. Survey.) Operator: Frank A. Malorey, North Chelmsford, Mass.

The granite, "Oak Hill," is a muscovite-biotite granite gneiss of very light gray shade and of medium gneissic, slightly porphyritic texture identical with that of the H. E. Fletcher quarry, described on page 266. It is also useful for the same purposes as the Fletcher granite.

The quarry, opened about 1830 , is from 700 to 1,000 feet in a northeast direction by 500 feet across and 40 feet deep. The stripping consists of 5 to 10 feet of sand and bowlders.

The sheets, 6 inches to 8 feet thick, dip $10^{\circ} \mathrm{NE}$., but are intersected on the east wall by secondary sheets 10 to 20 feet thick, dipping $20^{\circ} \mathrm{N} .47^{\circ}$ E..$^{1}$ There is but one set of joints, which strike N. $75^{\circ}$ E., dip $90^{\circ}$ or steep, and are spaced on the average 50 feet. The gneiss foliation, shown by banding, strikes $\mathrm{N} .40^{\circ} \mathrm{E}$. The rift is horizontal and the grain vertical, with $\mathrm{N}$. $35^{\circ} \mathrm{E}$. course. The stone splits better along the foliation than along the grain. There are dikes of pegmatite and aplite with black tourmaline. The aplite, consisting of potash feldspars, quartz with rutile and cavities, oligoclase-albite, apatite needles, carbonate, and epidote, but no mica, has bands of black tourmaline 0.4 inch apart and 0.2 inch wide.

1 The only other New England granite quarry in which secondary sheet structure has been observed is the Fletcher quarry on Robeson Mountain, in Woodbury, Vt. See Bull. U. S. Geol. Survey No. 404, 1909 , p. 17, Pl. IV, $B$. 
An inclusion, 2 by 18 inches, of fine banded biotite gneiss was noticed. There is very little rusty stain.

The plant comprises three derricks, two hoisting engines, two steam drills, and a steam pump.

Transportation is by cart to Woods Corners siding, about 2 miles.

The product is used mostly for curbing and paving and finds a market mostly in eastern Massachusetts.

\section{PETERSON QUARRY.}

The Peterson quarry is on Oak Hill, in Westford Township, a little over half a mile about north-northwest of the H. E. Fletcher quarry. Operators: Peterson Bros., West Chelmsford, Mass.

The granite (specimens $\mathrm{D}, \mathrm{XXX}, 94, \mathrm{a}, \mathrm{b}$ ) is similar to that of the H. E. Fletcher quarry described on page 266 , but a little coarser.

The quarry, opened in 1899 , is 200 feet square and 15 to 30 feet deep. The stripping consists of 5 or 6 feet of sand and bowlders.

The sheets, 8 inches to 6 feet thick, dip $5^{\circ}$ to $10^{\circ} \mathrm{SE}$. There are two sets of joints. Set $a$ strikes N. $15^{\circ}$ to $30^{\circ}$ E., dips steep to $90^{\circ}$, and is spaced 10 to 75 feet. Set $b$ strikes N. $65^{\circ} \mathrm{W}$., dips $60^{\circ} \mathrm{S} .25^{\circ} \mathrm{W}$., also N. $25^{\circ} \mathrm{E}$. The gneiss foliation strikes N. $40^{\circ} \mathrm{E}$. and dips $70^{\circ} \mathrm{S}$. $50^{\circ} \mathrm{E}$. The rift is horizontal and grain vertical, with N. $27^{\circ} \mathrm{E}$. course. Pegmatite dikes up to a foot thick have a N. $60^{\circ} \mathrm{W}$. course. Rusty stain up to 6 inches thick is confined mostly to the thin sheets. There is a compressive strain in the grain direction.

The plant comprises a derrick, a hoisting engine, and a steam pump.

Transportation is by cart to Woods Corners siding, 3 miles.

The product is used for trimmings, steps, sills, and curbing. Specimens: Trimmings on school buildings in Newton and Malden; Massachusetts Mills, East Merrimac Street, Lowell.

PERLEY CARKIN QUARRY.

The Perley Carkin quarry adjoins the Peterson quarry on the northeast. Operator: Perley Carkin, North Chelmsford, Mass.

The granite is identical with that of the Peterson quarry.

The quarry, opened in 1905, is 400 by 200 feet and 15 to 34 feet deep. The stripping consists of 2 to 8 feet of sand.

The sheets, 1 foot to 8 feet 4 inches thick, are about horizontal. The only joints strike N. $15^{\circ}$ to $30^{\circ} \mathrm{E}$., are vertical or steep, and are spaced 30 to 140 feet. Foliation, rift, and grain are the same as in the Peterson quarry. The amount of stain is small.

The plant comprises a derrick and hoisting engine, a horse derrick, two landing derricks, two steam drills, and two steam pumps.

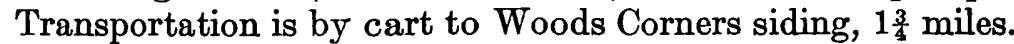

The product is used for curbing, paving, and trimming. 


\section{W. CARKIN QUARRY.}

The C. W. Carkin quarry is nearly one-quarter mile east of the Perley Carkin quarry. Operator: C. W. Carkin, North Chelmsford, Mass.

The granite is identical with that of the Peterson quarry.

The quarry is 200 by 60 feet and 10 to 15 feet deep.

The sheets, 6 inches to 4 feet thick, are horizontal. Two joints, one on either side of the quarry, strike N. $30^{\circ} \mathrm{E}$. Foliation, rift, and grain are the same as in the Peterson quarry.

The plant consists of a horse derrick and siphon pipe.

The product is used for curbing, paving, and trimming.

\section{CARTWRIGHT QUARRY.}

The Cartwright quarry is on Oak Hill, in Westford Township, about a mile north-northwest of the H. E. Fletcher quarry and nearly half a mile southeast of the Oak Hill quarry. Operators: Cartwright Bros., Tyngsboro, Mass.

The granite is identical with that of the quarries above mentioned.

This is part of an old quarry reopened in 1909. It is 50 feet square and 5 to 10 feet deep. The sheets are 5 to 10 feet thick.

There is one derrick and the product is used for curbing.

\section{MORRIS \& LUKE QUARRY.}

The Morris \& Luke quarry is in the northeastern part of Westford Township, about half a mile east of the Oak Hill quarry. Operators: Morris \& Luke, North Chelmsford, Mass.

The granite is like that of the Oak Hill quarry.

The quarry, opened in April, 1910, is 50 feet square and has penetrated only the first sheet, which is 8 feet thick. The rift is horizontal and the grain vertical with N. $25^{\circ}$ to $30^{\circ} \mathrm{E}$. course, but the stone splits only along the rift from the hardway side even after the block is detached. There is an aplitic dike up to an inch thick, with a central band of black tourmaline and rust stains whose source is not clear. The plagioclase has much carbonate and the quartz has apatite needles.

There is a hand derrick. The product is used for curbing and paving and carted $1 \frac{1}{2}$ miles to Woods Corners siding.

\section{H. N. FLETCHER QUARRIES.}

The H. N. Fletcher quarries are on the top and south side of Snake Meadow Hill, in Westford Township, about half a mile north-northwest of Graniteville station. (See map of Lowell quadrangle, U. S. Geol. Survey, and Pl. V.) Operator: H. N. Fletcher, Graniteville, Mass. 
The granite (specimen D, XXX, 101, a), "Graniteville," is a muscovite-biotite-quartz monzonite gneiss of very light gray shade and of gneissic, medium inclining to fine, slightly porphyritic texture, with feldspars up to 0.3 inch but mostly not over 0.2 inch and micas up to 0.2 inch. Its constituents, in descending order of abundance, are milk-white soda-lime feldspar (oligoclase-albite), generally kaolinized and micasized, some with bent laminæ; clear colorless quartz, granulated, with particles mostly not over 0.25 millimeter, and with rutile needles; bluish translucent potash feldspar (microcline and orthoclase); muscovite (white mica) and stringers of fibrous muscovite; and biotite (black mica), some of it chloritized. Accessory: Garnet. Secondary: Kaolin, white micas, epidote, and carbonate. The quartz forms a matrix of fine particles in which the feldspars lie. The rock shows some effervescence with hydrochloric-acid test.

The gneiss in places is coarsely porphyritic (specimen $\mathrm{D}, \mathrm{XXX}$, $101, \mathrm{~b})$, of medium-gray shade with dark bluish-gray feldspars up to an inch square and even 2 inches by 0.75 inch. The matrix has feldspars up to 0.2 inch and micas up to 0.1 inch. The feldspars are microperthite- potash feldspar (microcline), minutely intergrown with soda-lime feldspar (oligoclase-albite).

Some of the foliation faces of the gneiss carry muscovite crystals (specimen D, XXX, 102, a).

The stone of these quarries is generally lighter than that of the Oak Hill quarries but possesses the same general character and qualities.

The north quarry, opened in 1906, is 250 feet square but has an unexcavated part 50 by 125 feet on one side. The stripping consists of 2 to 6 feet of clay and sand. The sheets, 1 to 6 feet thick, undulate horizontally. There are five sets of joints. Set $a$ strikes N. $70^{\circ} \mathrm{E}$., dips $45^{\circ} \mathrm{S} .20^{\circ} \mathrm{E}$., and is spaced 20 feet. Set $b$ strikes N. $10^{\circ} \mathrm{W}$., forms a heading 70 feet wide beyond the east wall. Set $c$ strikes N. $20^{\circ}$ W., dips steep to $90^{\circ}$, and is spaced 8 feet. Set $d$, vertical, strikes N. $10^{\circ} \mathrm{E}$. Set $e$ strikes N. $30^{\circ}$ to $40^{\circ}$ E., dips $70^{\circ}$ N. $55^{\circ} \mathrm{W}$. to $90^{\circ}$, forms the east wall, and is spaced 50 feet and over. The rift is horizontal and the grain vertical, with N. $30^{\circ}$ E. course. The foliation is plicated, with a strike of N. $40^{\circ} \mathrm{E}$. Pegmatite lenses occur.

The south quarry, opened in 1860 , is 200 by 150 feet and 10 to 40 feet deep. The sheets, rift, and grain are the same as in the north quarry. There are two sets of joints. Set $a$, vertical, strikes N. $35^{\circ} \mathrm{E}$., and is spaced 4 to 10 feet. Set $b$, vertical, strikes $N .75^{\circ} \mathrm{W}$., and is spaced 3 to 6 feet.

The plant of both quarries comprises four derricks, a hoisting engine, a steam drill, and a steam pump.

Transportation is by cart to Graniteville station, one-half mile.

The product is used mostly in curbing and paving and is marketed in eastern Massachusetts. 


\section{PALMER QUARRIES.}

The Palmer quarries are on the north side of Snake Meadow Hill, in Westford Township. (See map of Lowell quadrangle, U. S. Geol. Survey.) Operator: Lewis P. Palmer, Graniteville, Mass.

The granite of the upper quarry (specimens D, XXX, 92, b, c), "Graniteville," is a muscovite-biotite-quartz monzonite gneiss of medium-gray shade and gneissic, slightly porphyritic, medium inclining to fine texture, with feldspar up to 0.3 inch and micas up to 0.2 inch, rarely 0.3 inch. The stone of the lower quarry is reported as a little coarser than this. The constituents, in descending order of abundance, are grayish soda-lime feldspar, kaolinized and micasized; in about equal amount, bluish-gray potash feldspar (microcline and orthoclase), intergrown with quartz that is circular in cross section; light smoky quartz finely granulated with particles up to 0.25 (rarely 0.37 ) millimeter, and with rutile. needles and cavities; muscovite (white mica), some with prism faces, also fibrous muscovite stringers; and biotite (black mica), some of it chloritized. Accessory: Magnetite and apatite. Secondary: Epidote, carbonate, kaolin, and white micas. It effervesces slightly with hydrochloric-acid test.

This is a useful-stone where greater transverse strength is required in one direction than in another. It is devoid of mineral contrasts and structurally resembles that of the Oak Hill quarries, but its shade is a little darker and its mineral composition slightly different. It is much darker than the gneiss of the $\mathrm{H}$. N. Fletcher quarry.

The upper quarry is about 300 by 215 feet and 20 to 40 feet deep. The stripping is 3 feet of sand. The lower quarry, 600 feet east of the upper, is about 200 by 100 feet and 15 feet deep.

The sheets in the upper quarry are 1 to 5 feet thick and dip $10^{\circ}$ about northeast; in lower quarry they are 2 to 7 feet thick and about horizontal. There are four sets of joints. Set $a$ strikes N. $20^{\circ}$ E., $\operatorname{dips} 75^{\circ} \mathrm{N} .70^{\circ} \mathrm{W}$., and forms the west walls. Set $b$, vertical, strikes N. $35^{\circ} \mathrm{W}$., and is spaced 50 feet. Set $c$ strikes about east and west, dips $70^{\circ} \mathrm{N}$. to $90^{\circ}$, and forms the north and south walls. Set $d$, vertical, strikes N. $10^{\circ} \mathrm{W}$., and forms a 20 -foot heading. The gneiss foliation strikes $\mathrm{N} .45^{\circ}$ to $60^{\circ} \mathrm{E}$., and dips $75^{\circ} \mathrm{SSE}$. to $90^{\circ}$. The rift is horizontal and the grain vertical, with northeast course like the foliation. The grain face is thus more micaceous than the rift face. There is a 12-inch dike of alternating bands of aplite and pegmatite with a N. $20^{\circ}$ E. course. A fine-grained inclusion of biotite schist or gneiss with zoisite from this quarry has been described on page 242 . Rusty stain is up to 3 inches thick on sheet surfaces.

The plant comprises nine derricks, three hoisting engines, an air compressor (capacity 300 cubic feet of air a minute), seven air plug drills, and two steam pumps. 
Transportation is by cart to Graniteville station, three-fourths of a inile.

The product is used for building, curbing, and paving.

COUTURE QUARRY.

The Couture quarry lies on the west side of Snake Meadow Hill, in Westford Township. Operators: Couture \& Son, Graniteville, Mass. The granite is like that of the Palmer quarries (p. 271).

The quarry, opened in 1906, is 150 by 100 feet and 12 feet deep. The stripping consists of 2 to 8 feet of clay.

The sheets, 2 to 12 feet thick, are horizontal. There are three sets of joints. Set $a$, vertical, strikes N. $10^{\circ}$ W., and is spaced 3 to 12 feet. . Set $b$ strikes N. $30^{\circ}$ E., dips $70^{\circ}$ S. $60^{\circ}$ E., and also N. $60^{\circ} \mathrm{W}$. Set $c$ strikes N. $80^{\circ} \mathrm{E}$., is spaced 10 to 20 feet, coated with epidote and quartz crystals and slickensided, and crosses the quarry lengthwise in the center. Rift, grain, and foliation are as in the other quarries of this hill.

The plant consists of one horse derrick and one hand derrick.

Transportation is by cart to Graniteville station, about threefourths of a mile.

The product is used for curbing.

\section{WRIGHT QUARRY.}

The Wright quarry is on the east side of Snake Meadow Hill, in Westford Township. Operator: Hammett D. Wright, Graniteville, Mass.

The granite is the same as that of the Palmer quarries (p. 271).

The quarry, opened in 1880 , is 300 by 150 feet and 15 to 20 feet deep. The part now worked measures about 150 by 50 feet.

The sheets, 6 inches to 3 feet thick, are horizontal. There are three sets of joints. Set $a$, vertical, strikes N. $10^{\circ} \mathrm{W}$., and forms a heading on the east wall. Set $b$ strikes N. $10^{\circ} \mathrm{E}$., one near west wall, one in center, and possibly others concealed by waste. Set $c$, steep, strikes N. $45^{\circ} \mathrm{E}$., and forms the west wall. The gneiss foliations strikes $\mathrm{N} .50^{\circ} \mathrm{E}$. Pegmatite and aplite dikes up to a foot thick have northerly courses.

The plant comprises two horse derricks and the product is used for curbing.

\section{HILDRETH QUARRY.}

The Hildreth quarry lies south of the Couture quarry, on the west side of the hill, in Westford Township. Operator: H. V. Hildreth, Westford, Mass.

The granite is like that of the Palmer quarries (p. 271).

The quarry, opened about 1845 , is 300 by 150 feet and 10 to 40 feet deep. 
The sheets, 1 to 13 feet thick, dip at a low angle to the north. There are two sets of joints. Set $a$, vertical or steep, strikes N. $10^{\circ}$ $\mathrm{E}$, forms east and west walls, and is spaced 150 feet. Set $b$, discontinuous, strikes N. $50^{\circ}$ E., dips $60^{\circ} \mathrm{N} .40^{\circ} \mathrm{W}$., forms a heading on the east wall, and is spaced 2 to 10 feet. Rift, grain, and foliation are as at the other quarries of this hill. Rusty stain is up to 4 inches thick on sheet surfaces.

The plant comprises two derricks, a hoisting engine, and a siphon pipe.

The product is used for building and curbing.

TOWNSEND.

BARKER HILL QUARRY.

The Barker Hill quarry is on the southwest side of that hill, about 200 feet above the railroad in the township of Townsend, $1 \frac{1}{2}$ miles north-northwest of West Townsend station and about $1 \frac{1}{4}$ miles north of West Townsend village. (See map of Groton quadrangle, U. S. Geol. Survey, and Pl. V.) Operator: West Townsend Granite Syndicate, West Townsend, Mass.

The granite (specimen D, XXX, 113, b), "West Townsend white," is a biotite-quartz monzonite of very light, faintly buff-gray color and of even-grained medium inclining to fine texture, with feldspars under 0.3 inch, rarely over $0.4 \mathrm{inch}$, and mica up to $0.1 \mathrm{inch}$. Its constituents, in descending order of abundance, are colorless, clear to translucent potash feldspar (microcline), much kaolinized and intergrown with quartz that is circular in cross section; in nearly equal amount, milk-white to faint pinkish soda-lime feldspar (oligoclase-albite), somewhat micasized; light smoky quartz with cavities in sheets; biotite (black mica); and a little muscovite or bleached biotite. Accessory: Magnetite, plentiful, apatite, zircon, and rutile (?) needles in chlorite. Secondary: Chlorite after biotite, carbonate, a white mica, and hematite stain from the magnetite. The polished face shows magnetite. It effervesces with hydrochloricacid test.

A pinkish variety (specimens D, XXX, 113, a, d, e), "West Townsend red," is of light to medium pinkish-gray shade and of the same texture and composition as the "white," but the thin section shows pyrite and what is possibly altered allanite, with radiating cracks filled with hematite stain.

This is a constructional and monumental granite of slightly coarser texture than the monumental granite of South Brookline, N. H., and probably of the same geologic age. South Brookline is only 4.4 miles east-northeast of this quarry. ${ }^{1}$ The stone takes a good polish.

${ }^{1}$ See Bull. U. S. Geol. Survey No. 430, 1910, pp. 362-363; also map of Groton quadrangle, U. S. Geol. Survey.

$94174^{\circ}-$ Bull. $470-11-18$ 
The quarry, opened in 1907, is 225 by 150 feet and 5 to 15 feet deep. The stripping consists of 1 to 6 feet of sand and bowlders.

The sheets, 1 to 5 feet thick, are about horizontal. There are no joints. The rift is horizontal and the grain vertical, with $\mathrm{N} .80^{\circ} \mathrm{W}$. course. A pegmatite dike up to 4 feet thick has a N. $55^{\circ} \mathrm{W}$. course. There are also lenses of pegmatite. The inclusion of biotite or diorite gneiss referred to on page 242 came from below the quarry. Rusty stain is up to 6 inches thick.

- The plant comprises four derricks and three hoisting engines, an air compressor (capacity 175 cubic feet of air a minute), four air plug drills, ten air hand tools, a surfacer, and a steam drill.

Transportation is by cart to the railroad, one-third mile.

The product is used mostly for buildings, but partly for monuments, and finds a market in New England. Specimens: Entire front of Thames National Bank, Norwich, Conn.; trimmings to the following buildings: Alvirnè Memorial Chapel, Hudson, N. H.; post office, Nashua, N. H.; Thompson Memorial Chapel, Williams College, Williamstown, Mass.

\section{NORFOLK COUNTY.}

WRENTHAM.

CURRY QUARRY.

The Curry quarry is on High Rock, in Wrentham Township, about $2 \frac{1}{2}$ miles east-southeast of Wrentham station. (See map of Franklin quadrangle, U.S. Geol. Survey, and Pl. V.) Operator: R. H. Curry, Foxboro, Mass.

The granite (specimen D, XXX, 115, a), "Wrentham," is a hornblende granite of light-gray shade and of even-grained medium inclining to coarse texture, with feldspars up to 0.5 inch and mica up to 0.1 inch. Its constituents, in descending order of abundance, are very light gray to pale cream-colored microperthite (potash feldspar (microcline and orthoclase), somewhat kaolinized, minutely intergrown with soda-lime feldspar); medium smoky quartz with abundant cavities in sheets; clear colorless to milk-white striated sodalime feldspar (oligoclase-andesine), much kaolinized, also micasized and epidotized, in some crystals from within outward, and hornblende associated with epidote. Accessory: Magnetite. Secondary: Kaolin, a white mica, epidote, and carbonate. It shows very slight effervescence with hydrochloric-acid test:

This is an attractive stone with marked mineral contrasts and is suitable for substantial structures.

The quarry, opened in 1884, is about 150 feet square and 25 to 35 feet deep. The stripping is a foot of sand and soil.

The sheets, 4 to 16 feet thick (one a foot thick), are horizontal or $\operatorname{dip} 15^{\circ} \mathrm{E}$. or $\mathrm{W}$, and are likely to have 2 inches of decomposed granite 
between them. One set of joints, vertical, strikes N. $10^{\circ} \mathrm{E}$., is spaced 2 to 100 feet, and is coated with epidote. Another set, striking N. $60^{\circ} \mathrm{E}$. and dipping $70^{\circ} \mathrm{N} .30^{\circ} \mathrm{W}$., forms headings of very close joints in the upper 10 feet of the rock. (See p. 246.) An obscure flow structure dips about $55^{\circ} \mathrm{N}$. The rift is horizontal and the grain vertical, with N. $80^{\circ} \mathrm{W}$. course. "Knots" are from 1 to 6 inches across. Rusty stain is 2 feet thick on the top sheet.

The plant comprises a horse derrick, a steam derrick, a hoisting engine, and a steam drill.

Transportation is by cart to local customers.

The product is used for building, curbing, and monuments.

\section{PLYMOUTH COUNTY.}

\section{BROCKTON.}

BROCKTON HEIGHTS QUARRY.

The Brockton Heights quarry is on Pearl Street, Brockton Heights, about $2 \frac{1}{2}$ miles west of Brockton station in the same township. (See map of Dedham quadrangle, U. S. Geol. Survey, and Pl. V.) Operator: Brockton Pink Granite Co., room 530, Old South Building, Boston, Mass.

The granite (specimen D, XXX, 130, a), "Brockton pink," is a biotite-hornblende (or altered augite-hornblende) granite of light greenish-gray color with large pink spots and matrix of medium texture (feldspars up to 0.3 inch and mica up to $0.2 \mathrm{inch}$ ) and with porphyritic light pink feldspars up to $0.8 \mathrm{inch}$. The constituents of the matrix, in descending order of abundance, are milk-white to greenish soda feldspar (albite), much micasized; clear colorless to slightly milky quartz with cavities in sheets; chlorite, probably after biotite (possibly after augite); a little microperthite (potash feldspar (microcline), minutely intergrown with soda feldspar (albite), kaolinized; with epidote and zoisite in microscopic particles); and yellow hornblende in fibrous radiating crystals. The large pink crystals are also microperthite and contain sparse groups of yellow hornblende crystals. Accessory: Magnetite and titanite. Secondary: Epidote, zoisite, plentiful carbonate, chlorite, a white mica, kaolin, and quartz. There are veinlets of carbonate, epidote, and quartz. The stone effervesces with hydrochloric-acid test.

This granite is unique in New England, on account of both its texture and its green and pink mineral contrasts. It takes a high polish. If obtainable in large, sound slabs it would be admirably adapted to interior decorative use. Physical tests are said to show that it possesses about the same strength and hardness as Quincy granite.

The quarry, opened in 1900, is 20 feet square and 15 feet deep. The areal extent of the rock is reported as about 7 acres, which probably only signifies the extent of the outcrops. 
Sheet and joint structure are both defective and there is no perceptible rift or grain.

The plant comprises a derrick, a hoisting engine, a steam drill, and a stone crusher.

Transportation is by cart to North Easton station or Brockton station, $2 \frac{1}{2}$ miles.

The product is now confined to crushed stone, but it is hoped that as the quarry is deepened the rock structure may be found so much better that the stone can be profitably used for building. Specimen: Mattapan station on the New York, New Haven \& Hartford Railroad between Dedham and Quincy, Mass.

\section{HINGHAM.}

\section{HINGHAM SEAM-FACE QUARRIES.}

The Hingham seam-face quarries are in Hingham Township, 2 miles zouth-southeast of East Weymouth station and about three-fourths of a mile southeast of Lovell Corners. (See map of Abington quadrangle, U. S. Geol. Survey, and Pl. V.) Operator: Hingham Granite \& Contracting Co., 161 Summer Street, Boston, Mass.

The granite (specimens D, XXX, 124, a, b), "Hingham," is an aplite of light, slightly greenish gray color and of fine, slightly porphyritic texture, with feldspars up to 0.2 inch. Its constituents, in descending order of abundance, are milk-white soda-lime feldspar (oligoclase-albite), much kaolinized and micasized and a little epidotized, the alteration proceeding from within the crystals outward; clear, colorless quartz, with cavities, rare particles of smoky quartz up to 0.1 inch; pale-greenish potash feldspar (microline), a little kaolinized; very little biotite, and more of chlorite after biotite, both in small particles and sparse. Accessory: Pyrite, plentiful, and magnetite. Secondary: Kaolin, a white mica, chlorite, and epidote, mostly about the chlorite. It shows no effervescence with hydrochloric-acid test.

The following analysis of the fresh aplite made in 1900 by F. J. Moore and given in a report made to the company by W. O. Crosby and G. F. Loughlin is published here for reference:

Analysis of aplite from Hingham, Mass.

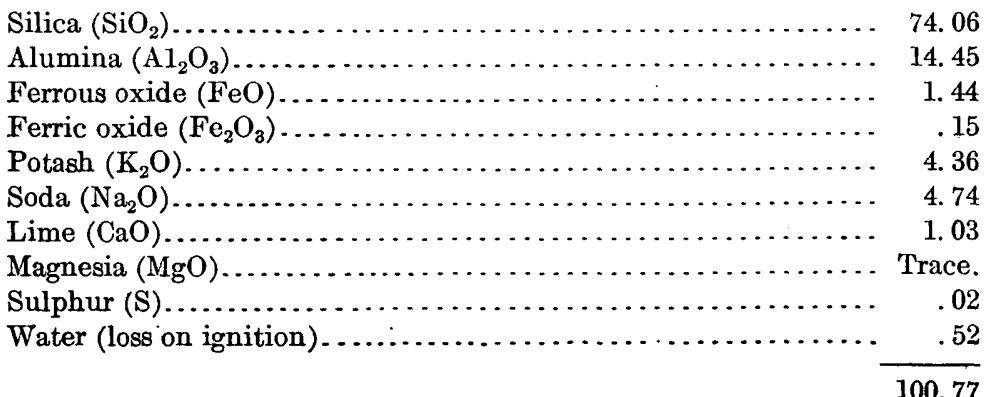

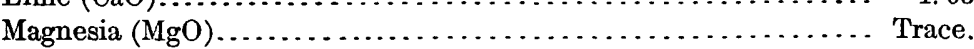

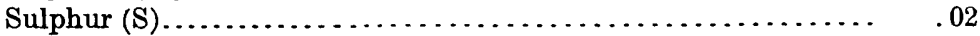

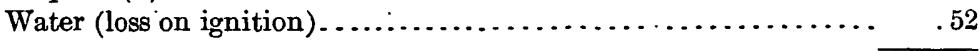


The 0.02 per cent of sulphur is equivalent to about 0.04 per cent of pyrite. Traces of manganese and phosphoric acid were noted.

The same report gives the following additional determinations made by A. A. Blanchard in 1910:

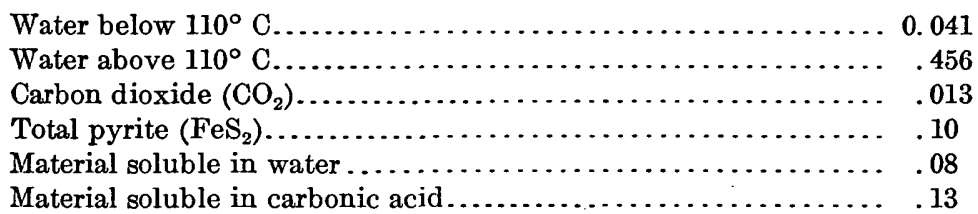

Tests made at the Watertown arsenal in 1910 on specimens of the fresh aplite show a crushing strength ranging from 32,900 to 39,800 pounds to the square inch. Tests of the transverse breaking strength of the fresh aplite made for the company by Crosby and Loughlin gave these results:

Results of tests of breaking strength of aplite from Hingham, Mass.

\begin{tabular}{|c|c|c|c|c|}
\hline $\begin{array}{l}\text { Number } \\
\text { of tests. }\end{array}$ & $\begin{array}{l}\text { Size of } \\
\text { beams. }\end{array}$ & Span. & $\underset{\text { (pounds). }}{\text { Maximum load }}$ & $\begin{array}{c}\text { Transverse } \\
\text { breaking } \\
\text { strength } \\
\text { (pounds per } \\
\text { square inch). }\end{array}$ \\
\hline $\begin{array}{l}4 \\
4 \\
2\end{array}$ & $\begin{array}{r}\text { Inches. } \\
3 \text { by } 6 \\
4 \text { by } 8 \\
4 \text { by } 8\end{array}$ & $\begin{array}{r}\text { Inches. } \\
12 \\
12 \\
19\end{array}$ & $\begin{array}{l}10,090-22,310 \\
20,610-49,420 \\
16,820-17,700\end{array}$ & $\begin{array}{l}3,320-3,770 \\
2,950-3,470 \\
3,400-3,660\end{array}$ \\
\hline \multicolumn{4}{|c|}{ Generat average $\ldots \ldots \ldots \ldots \ldots \ldots \ldots \ldots$} & 3,440 \\
\hline
\end{tabular}

In comparison with these results two Watertown arsenal tests of Rockport granite, 4 by 8 inch beams and 19-inch span, show transverse breaking strengths of 2,404 to 2,416 pounds; and one of Milford (Mass.) granite, 1,745 pounds.

Tests of porosity and absorption made for the company by Crosby and Loughlin on four 3-inch cubes of the rusty aplite show from 0.285 to 0.371 per cent or 0.04 to 0.55 gram per square inch of surface. In these tests the cubes were first dried at $110^{\circ} \mathrm{C}$. for 24 hours, weighed, soaked for 48 hours in distilled water, the first two hours in boiling water, and then weighed again after removing excess water. Similar tests with two 4-inch cubes of the fresh aplite, which, however, were soaked for six weeks instead of two days, showed only 0.0052 gram per square inch of surface.

The specific gravity of the fresh aplite was found by the same persons to be 2,637, which corresponds to a weight of 164.8 pounds per cubic foot.

The quarries, begun many years ago for rough-faced stone but only in 1891 for seam-faced stone, comprise three openings. The largest (No. 1) is 150 feet square and 25 to 45 feet deep. No. 3, situated 600 feet S. $80^{\circ}$ E. of No. 1, is 75 by 30 feet and 10 to 20 feet deep. 
At the largest opening the sheets, which are very imperfectly developed and 4 inches to 6 feet thick, dip $5^{\circ}$ to $20^{\circ} \mathrm{NW}$. There are five sets of joints. Set $a$, vertical, with N. $25^{\circ} \mathrm{E}$. strike, forms a wide heading with joint spaces 2 inches to 2 feet 6 inches. Set $b$ strikes N. $25^{\circ}$ W., dips steep N. $65^{\circ}$ E. and is spaced 10 to 30 feet. Set $c$ strikes N. $55^{\circ}$ W., dips $70^{\circ}$ N. $35^{\circ}$ E.; only two 2 feet apart. Set $d$ strikes N. $30^{\circ}$ W., diagonal to quarry, dips steep S. $60^{\circ} \mathrm{W}$.; one only. Set $e$ strikes N. $77^{\circ}$ W., dips steep N. $13^{\circ}$ E., and forms the north and south walls.

At opening No. 3 there are no sheets whatever. Joint set $a$ forms a heading in which the spacing is 8 inches to 3 feet. Set $b$ has a dip of $75^{\circ} \mathrm{S}$. $65^{\circ} \mathrm{W}$. to $90^{\circ}$ and is spaced 10 to 30 feet. Set $c$ dips $40^{\circ} \mathrm{S} .35^{\circ} \mathrm{W}$.

All these sheet and joint faces are more or less stained with limonite from 0.06 to 2 inches thick, due to the oxidation of the somewhat plentiful pyrite. There are grayish knots up to 0.5 inch, rarely 2 by 10 inches.

Owing to the hardness of the granite, the scarcity of sheets, the superabundance of joints and headings, and the prevalence of "sap" these would be very discouraging quarries to -work for ordinary purposes, but in supplying the demand for rusty seam-faced stone their petrographic and structural features are turned to good account. Blocks from 4 to 15 inches thick with a seam face are used either as trimmings or for the main exterior, and the rough-faced unstained stone is used as trimmings. (See p. 247.) The following quotation concerns this phase of the granite industry: ${ }^{1}$

To the ordinary uses to which granite is put, there must be added the somewhat recent demand for the sap portions for decorative ashlar work and rustic masonry. Those quarries which possess sap rock of the desirable colors are earning a new and adventitious revenue. In fact, the increasing demand for seam-faced granite and other rocks has led to the opening of several granite quarries which produce only stock of this kind. The demand for seam-face granite is steadily increasing; its introduction is becoming more general and its artistic merits are winning better appreciation.

The plant comprises four derricks, a hoisting engine, a steam drill, a steam pump, and a Blondin carrier of 2 to 3 tons capacity, to which a stone crusher is to be added.

Transportation is by cart either to East Weymouth station, 2 miles, or direct to Boston, 16 miles.

The product finds a market in eastern Massachusetts. The intersection of some of the joints and sheets makes it possible to obtain a regular supply of rusty seam-faced stones with angles of $90^{\circ}$ or $120^{\circ}$. The great crushing strength of this aplite has brought it into demand for keystones for tunnel arches. It is also proposed, as explained on page 247 , to supply stones for decorative bands, in which part of the rusty face is to be cut away.

1 Whittle, C. L., The buiiding and road stones of Massachusetts: Mineral Industry, vol. 7, 1898, New York and I.ondon, 1899, p. 638. 


\section{MILLER SEAM-FACE QUARRY.}

The Miller seam-face quarry is in Hingham Township about $2 \frac{1}{4}$ miles south-southeast of East Weymouth station and a mile eastsoutheast of Lovell Corners. (See map of Abington quadrangle, U. S. Geol. Survey.) Operator: J. E. L. Miller, East Weymouth, Mass.

The granite (specimen D, XXX, 125, b), "Weymouth," is an aplite identical with that of the quarries last described and evidently belongs to the same mass. In thin section the biotite appears less altered to chlorite.

The quarry, opened in 1901, is triangular in area, 100 feet on two sides and 125 feet on the other, and from 30 to 45 feet deep.

There are no sheets, but three sets of joints. Set $a$, striking N. $25^{\circ}$ E., forms headings with joint spaces of 2 inches to 3 feet. Set $b$, vertical, strikes N. $25^{\circ} \mathrm{W}$. and is spaced 10 to 25 feet. Set $c$ strikes N. $65^{\circ} \mathrm{E}$. and dips $40^{\circ} \mathrm{S} .25^{\circ} \mathrm{E}$. A diabase dike, 18 inches thick, strikes about east and west, dipping at a steep angle to the north.

The plant comprises a derrick, a hoisting engine, a steam drill, and a pump.

The product, used mostly for seam-faced work, is carted to East Weymouth. Specimens: Gateway, Albany Rural Cemetery; Episcopal churches, Holyoke and Brookline; Baptist Church, Brockton; Unitarian Church, Winchester; Methodist Episcopal Church, Dorchester, Mass.; bridge, Waterbury, Conn., built by the city.

Trimmings of seam-faced aplite from one of the Hingham quarries are to be used in the new building of Faith Church, Springfield, Mass.

\section{SUFFOLK COUNTY.}

\section{REVERE.}

\section{BLACK ANN HILL QUARRY.}

The Black Ann Hill quarry is at the southeast foot of Black Ann Hill, in North Revere, that part of Revere Township which lies between the townships of Malden and Saugus. (See map of Boston quadrangle, U. S. Geol. Survey, and Pl. V.) Operators: H. \& D. Burnett, Franklin Park, Mass.

The rock (specimen D, XXXII, 13, a), "Revere," is a rhyolitic felsite porphyry ${ }^{1}$ of very dark purplish-gray color and of dense, apparently homogeneous texture, with very minute whitish veins and close joint faces coated with films of calcite. It effervesces with hydrochloric-acid test. Under the microscope it shows a fluidal spherulitic banded texture, with porphyritic crystals of orthoclase (?), albite, and oligoclase; also particles of quartz and rare scales of 
biotite and chlorite. Accessory: Magnetite and zircon. Veinlets of quartz and carbonate fault the feldspars. Secondary: White micas, epidote, carbonate, quartz, and chlorite.

The quarry has an east-west working face 75 to 100 feet high and 200 feet long.

A trap or diabase dike crosses the felsite from east to west, tapering out.

The crusher, which is on Salem Street, has meshes of $\frac{3}{8}$ inch to $1 \frac{1}{4}$ inches.

Transportation is by cart to a siding on the Saugus branch of the Boston \& Maine Railroad, one-fourth mile.

The product is used for roads and concrete material and the $\frac{3}{8}$-inch screenings and dust are sought for use in concrete in the place of sand. This quarry supplied over 61,000 tons of crushed felsite for the construction of the East Boston tunnel and 21,000 tons to the United States Engineer Corps in 1898 for the construction of the battery at Fort Heath, in Winthrop. The dust was also used in 1908 in the concrete of two large schoolhouses, three fire-engine stations, two city stables, the hospital, and the armory in Chelsea.

H. A. Carson, chief engineer of the Boston Transit Commission, had the relative value of the dust of this felsite (with $\frac{3}{8}$-inch screenings) and of sand, for concrete, tested in beams of 30-inch span, with these results: ${ }^{1}$

Test of felsite dust and sand for concrete.

\begin{tabular}{|c|c|c|}
\hline & $\begin{array}{l}\text { A verage } \\
\text { breaking } \\
\text { strength. }\end{array}$ & $\begin{array}{l}\text { Average } \\
\text { modulus } \\
\text { of rup- } \\
\text { ture. }\end{array}$ \\
\hline 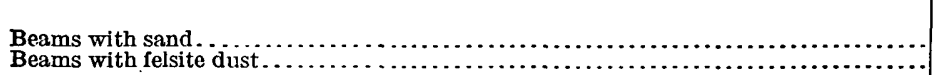 & $\begin{array}{r}\text { Pounds. } \\
3,347 \\
3,874\end{array}$ & $\begin{array}{l}660 \\
783\end{array}$ \\
\hline
\end{tabular}

WORCESTER COUNTY.

FITCHBURG.

MCCAULIFF QUARRY.

The McCauliff quarry is on the west side of Rollstone Hill in Fitchburg, ${ }^{2}$ a mile a little south of west of the Boston \& Maine Railroad station. (See map of Fitchburg quadrangle, U. S. Geol. Survey, and Pl. V.) Operator: F. A. McCauliff, 37 River Street, Fitchburg, Mass.

The granite (specimen D, XXX, 107, a), "Fitchburg," is a muscovite-biotite granite gneiss of light to medium bluish-gray color and

1 See report of chief engineer, in Seventh Ann. Rept. Boston Transit Comm., Aug. 15, 1901, Appendix A, p. 41.

2 This hill takes its name from a glacial bowlder, 10 by 8 feet of granitic rock, with 3-inch porphyritic crystals, which lies on its top. The hill itseif appears to be a granite dome. 
of gneissic medium texture, with feldspars up to 0.3 inch and micas up to 0.2 inch. Its constituents, in descending order of abundance, are bluish clear to translucent potash feldspar (microcline and orthoclase); light smoky quartz, finely granulated (particles under 0.37 millimeter), with rutile needles and cavities; milk-white sodalime feldspar (oligoclase-albite), kaolinized and micasized; muscovite (white mica) and fibrous muscovite in stringers; and biotite (black mica), some of it chloritized. Accessory: Garnet and apatite. Secondary: Kaolin, white micas, epidote, and chlorite. It shows no effervescence with hydrochloric-acid test.

This is a constructional granite gneiss of bright mineral contrasts.

The quarry, opened about 1865 , is triangular in area, measuring about 450 feet on its north side and 175 feet on its east side, which are the working faces, and is 10 to 20 feet deep.

The sheets, 1 to 8 feet thick, horizontal at the northeast corner of the quarry, dip away radially to an angle of $15^{\circ}$ in its lower part. There are four sets of joints. Set $a$ strikes N. $75^{\circ}$ W. to N. $75^{\circ}$ E., dips $65^{\circ}$ about south, forms the north wall, is spaced 3 to 20 feet, and the joints are tight and ferruginous. Set $b$, vertical, strikes $\mathrm{N}$. $5^{\circ} \mathrm{W}$.; only a few. Set $c$ strikes N. $60^{\circ} \mathrm{E}$., dips $75^{\circ} \mathrm{S} .30^{\circ} \mathrm{E}$., is spaced 12 feet and over; few and loose. Set $d$ strikes N. $20^{\circ}$ W., dips $45^{\circ} \mathrm{S}$. $70^{\circ} \mathrm{W}$.; three only, 20 to 150 feet apart. The gneiss foliation strikes N. $10^{\circ} \mathrm{E}$. and dips $55^{\circ} \mathrm{N} .80^{\circ} \mathrm{W}$. The rift is horizontal and the grain vertical, with $\mathrm{N} .80^{\circ} \mathrm{E}$. course. There are a number of pegmatite dikes up to 4 inches thick, with black tourmaline dipping $45^{\circ}$ about north and spaced 15 feet and over. Some of these dikes meander and combine. One is faulted along a N. $20^{\circ} \mathrm{E}$. plane. Another has a half-inch central band of smoky quartz and borders of feldspar and tourmaline. The stone is generally sound except near the main joints and for 2 or 3 inches along sheet surfaces.

The plant comprises four derricks, four hoisting engines, an air compressor (capacity 690 cubic feet of air a minute), fifteen air plug drills, four surfacers, two large rock drills, and a stone crusher with screens of $2 \frac{1}{2}, 1 \frac{1}{2}$, and $\frac{1}{2}$ inch meshes, and has a daily capacity of 90 tons.

Transportation is by cart to the railroad siding, one-eighth mile.

The best of the product is used for base courses, the seconds for curbing and paving, and the waste for concrete. Its market is chiefly local. Specimen: First story of high school, Fitchburg.

\section{LITCHFIELD QUARRY.}

The Litchfield quarry is on the southwest side of Rollstone Hill in Fitchburg, nearly a mile west-southwest of the Boston \& Maine Railroad station. (See map of Fitchburg quadrangle, U. S. Geol. Survey, and Pl. V.) Operator: O. E. Litchfield, Fitchburg, Mass. 
The granite is identical with that of the McCauliff quarry, described on page 280.

The quarry, opened in 1875, triangular in area, is 700 feet (originally 1,000 feet) in a northerly direction by 200 feet and 75 feet.

The sheets, 6 inches to 6 feet, some 15 feet thick, curve gently westward from the top of the hill. There is but one set of joints, which strike N. $70^{\circ}$ E., dip $45^{\circ}$ S. $20^{\circ}$ E.; two only, 50 feet apart, discontinuous. Foliation, rift, and grain are as at the McCauliff quarry. Pegmatite dikes up to 6 inches dip $50^{\circ} \mathrm{NE}$. At the southeast end is one, 2 feet thick, of smoky quartz, feldspar, muscovite, and black tourmaline. Some of these dikes are very micaceous, becoming the "sand seams" of quarrymen. The "sap" is 6 inches thick on the top sheets.

The plant comprises six derricks, two hoisting engines, a 50-horsepower air compressor, six air plug drills, three stream drills, and a stone crusher with $2 \frac{1}{2}, 1 \frac{1}{2}$, and $\frac{5}{8}$ inch meshes, and has a daily capacity of 200 tons.

The product is used for dimension stone, curbing, and paving. The smallest size from the crusher is used for graveling roofs. Specimens: Wallace Way, steps and buttresses to high school, and most of the stone in Episcopal Church chapel, Fitchburg.

\section{GODBEER QUARRY.}

The Godbeer quarry is on the northeast side of Rollstone Hill, in Fitchburg, about three-fourths of a mile west of the Boston \& Maine Railroad station. (See map of Fitchburg quadrangle, U. S. Geol. Survey, and Pl. V.) Operator: Henry Godbeer, Fitchburg, Mass.

The granite is identical with that of the McCauliff quarry, described on page 280.

The quarry is 250 feet in a northeast direction by 200 feet across and 5 to 10 feet deep.

The sheets, 1 to 8 feet thick, dip $20^{\circ} \mathrm{NE}$. Their variation in thickness is due to incomplete formation, "growing on." There are three sets of joints. Set $a$, vertical, strikes N. $40^{\circ}-60^{\circ} \mathrm{E}$., is spaced 10 to 20 feet, and has rusty faces. Set $b$ strikes N. $80^{\circ}$ E., $\operatorname{dips} 55^{\circ} \mathrm{S} .10^{\circ} \mathrm{E}$; f few. Set $c$ strikes N. $60^{\circ}$ W., dips $40^{\circ} \mathrm{S} .40^{\circ} \mathrm{W}$. ; few.

The plant comprises three derricks, two hoisting engines, an air compressor (capacity 210 cubic feet of air a minute), four air plug drills, a surfacer, and three steam drills.

Transportation is by cart to the railroad siding, half a mile.

The product is used for building and curbing. Specimen: Third story of Moran Building, Fitchburg. 


\section{LEOMINSTER.}

\section{LEAVITT QDARRY.}

The Leavitt quarry is in the township of Leominster, 2 miles west of that village and about 400 feet above it. (See map of Fitchburg quadrangle, U. S. Geol. Survey, and Pl. V.) Operators: F. M. Leavitt \& Co., Leominster, Mass.

The granite (specimen D, XXX, 110, a), "Leominster," is a mica diorite of dark bluish-gray shade (between "Barre dark" and "Quincy extra dark") and of very fine even-grained texture with particles under 0.1 inch. Its constituents, in descending order of abundance, are light-grayish soda-lime feldspar (oligoclase-andesine); biotite (black mica), with rare muscovite or bleached biotite; and very light smoky quartz. Accessory: Titanite (fourth in order of abundance), plentiful apatite needles, zircon crystals in strings, also branching, and pyrite. Secondary: Carbonate and chlorite. It effervesces with hydrochloric-acid test.

This is a handsome fine-grained dark stone, suitable for monuments or buildings. It ought to hammer light.

The quarry, opened in 1870, is 300 feet north and south by 200 feet across, and 5 to 30 feet deep.

The sheets, 6 inches to 5 feet thick, but mostly under 18 inches, $\operatorname{dip} 20^{\circ} \mathrm{E}$. There are two sets of joints. Set $a$, vertical, strikes N. $80^{\circ}$ E. and forms the south wall. Set $b$, vertical, strikes N. $5^{\circ}$ E., dips steeply east to $90^{\circ}$, and forms the east and west walls. The rift is parallel to the sheets and the grain vertical north to south. The quarry is crossed diagonally by a large ramifying dike of banded aplite and pegmatite which is described on page 242 and a horizontai section of which is shown in figure 38, p. 243. Minor dikes of aplite and also of pegmatite intersect the main dike. One 4 feet 6 inches thick is on the west wall. The diorite also has here and there white feldspar "knots" up to 1.5 inches across.

The plant comprises a derrick, a hoisting engine, and a steam drill. Transportation is by cart to Leominster station, $2 \frac{1}{4}$ miles.

The product is used for buildings, trimmings, curbing, flagging, and foundations and has a local market. Specimens: Haws Memorial Chapel in Evergreen Cemetery; trimmings to Mayo and Jones blocks, Leominster; and trimmings to Acre School, Clinton, Mass.

\section{UXBRIDGE.}

\section{BLANCHARD QUARRIES.}

The Blanchärd quarries are in Uxbridge Township, about $1 \frac{1}{2}$ miles west-northwest of Uxbridge station and 13 miles south-southeast of Whitinsville. (See map of Blackstone quadrangle, U. S. Geol. Survey, and Pl. V.) Operators: Blanchard Bros. Granite Co., Linwood, Mass. 
The granite (specimens D, XXX, 114, d, e), "Uxbridge," is a biotite granite gneiss of light to medium gray shade (light gray on rift face and medium gray on hardway face) and of medium porphyritic, elongated gneissic texture, with feldspars up to 0.4 inch (exceptionally 0.5 inch) and laminæ of quartz and mica up to 0.1 inch wide, alternating with laminæ of feldspar up to 0.3 inch wide. Its constituents, in descending order of abundance, are light-buff potash feldspar (microcline and orthoclase), slightly micasized; light smoky quartz with cavities in parallel and rectangular sheets; milk-white sodalime feldspar (oligoclase); biotite (black mica); and a little muscovite or bleached biotite. Accessory: Magnetite, apatite, and purple fluorite. Secondary: Carbonate, epidote, kaolin, and muscovite. It effervesces slightly with hydrochloric-acid test.

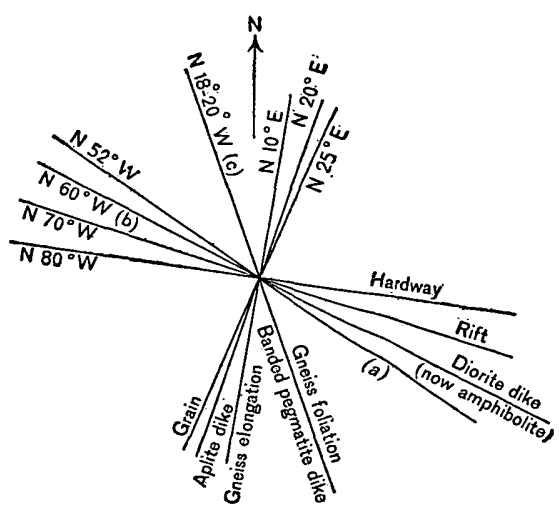

FiguRe 42.-Structure at Blanchard quarries, Uxbridge, Mass.

This gneiss resembles that of Sterling, Conn., and is a useful constructional stone.

The quarries, begun in 1864, consist of two openings. The larger is 300 by 200 feet and 20 to 50 feet deep, and the smaller, triangular in area, 100 feet on a side and 60 feet deep in the center. The stripping consists of 2 to 10 feet of gravel and bowlders.

As sheet structure is absent this is a "bowlder quarry." The courses of the joints, foliation, etc., are shown in figure 42 . Joint set $a$ dips $77^{\circ} \mathrm{S} .38^{\circ} \mathrm{W}$. and is spaced 5 to 40 feet. Set $b$ dips $30^{\circ} \mathrm{N}$. $45^{\circ}-60^{\circ} \mathrm{E}$. and is spaced 3 to 20 feet. Set $c$ dips $55^{\circ} \mathrm{S} .72^{\circ} \mathrm{W}$. and is spaced 10 to 60 feet. The foliation dips $35^{\circ} \mathrm{N}$. $70^{\circ} \mathrm{E}$. The rift dips $10^{\circ}-15^{\circ} \mathrm{N} .20^{\circ}$ E. and the grain and hardway are vertical. Aplite dikes are 2 inches to 3 feet thick. Pegmatite dikes of banded quartz and feldspar (described on p. 245) parallel to joints $c$ are up to 3 feet thick, and an amphibolite dike (described on p. 243) parallel to joints $b$ is 6 to 18 inches thick. The amount of sap varies greatly. Some blocks are free from it, some are all stained, on others it is a foot thick.

The plant comprises eight 10-ton derricks, four smaller ones, eight hoisting engines, a 16-ton locomotive, an air compressor (capacity 396 cubic feet of air a minute), nine air plug drills, two air hand tools, two surfacers, a hand surfacer, three steam drills, and a stone crusher with adjustable meshes and a daily capacity of 35 tons.

Transportation is by a private siding to the New York, New Haven

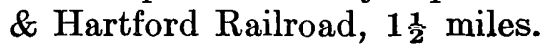


The product is used for buildings and bridges, the waste for foundations, paving, and crushed stone for concrete. Its market is eastern Massachusetts. Specimens: Tower and stonework of St. Charles Roman Catholic Church, Woonsocket, R.I. ; trimmings of city hospital, Providence, R. I.; trimmings of New York, New Haven \& Hartford Railroad station at Attleboro, Mass.; and of Holmes Manufacturing Co.'s mill, New Bedford, Mass.; town bridge over Quinebaug River at Southbridge, Mass.; and a number of bridges for the New York, New Haven \& Hartford Railroad in eastern Massachusetts.

\section{NOTE ON VALUES.}

The prices current in 1910 of two of the granites described here may be of service in placing them commercially: Oak Hill (Westford) granite gneiss, dimension stock, in the rough, f. o. b., per cubic foot, 30 to 40 cents; Fall River gneissoid granite, same stock, etc., 40 cents.

\section{ECONOMIC CLASSIFICATION OF MASSACHUSETTS GRANITES.}

In the following table all the "granites" described, as well as all the other commercial granites of Massachusetts described in Bulletin 354 , are classified according to their uses and are also designated by their scientific and trade names. This table thus gives a survey of all the commercial granites of the State. Where a granite is used for two purposes it is repeated in the grouping. 
Economic classification of the commercial granites of Massachusetts.

\begin{tabular}{|c|c|c|c|}
\hline & Locality. & lame. & General color and shade. \\
\hline & New B & New B & Light \\
\hline & Dartmouth & Dartmouth... & Very light buff gray.... \\
\hline & Fall River. & Fall River pink. & pinkish gray \\
\hline & & Fall Riv & Lig. \\
\hline & Fall River, Barlow & Fall River, Barlow & Medium bluish gray... \\
\hline & Rockport. & $\begin{array}{l}\text { Rockport gray, Bay } \\
\text { View gray. }\end{array}$ & Medium gray \\
\hline & .....do. & Babsol & Somer \\
\hline & $\begin{array}{l}\text { Lynnfield, Robin Rock } \\
\text { quarry. }\end{array}$ & Robin & $\mathrm{Ver}$ \\
\hline & Peabo & Peabody green & $\begin{array}{l}\text { Dark or very } \\
\text { gray. }\end{array}$ \\
\hline & Monson. & Monson & Dark or ver \\
\hline & Pelham. & Pelham. & Dark bluish gray.. \\
\hline ⿷ี & North Acton, Harris & Acton & Light bluish gray. \\
\hline 莺 & North Acton, Mc- & Acton, fine & Medium bluish gray \\
\hline 要 & Groton, Rafferty & Groton & Light to mec \\
\hline 8 & Groton, Shaker quarry. &.$d$ & Mediur \\
\hline & $\begin{array}{c}\text { Westford, Oak Hill } \\
\text { quarries, }\end{array}$ & Westford, Oak I & Very light or very light, slightly \\
\hline & $\begin{array}{l}\text { Westford, Snake Mea- } \\
\text { dow Hill quarries. }\end{array}$ & Granite & ay or mediux \\
\hline & West I & W & Lig \\
\hline & a, High Rock. & $\mathrm{Wr}$ & $\mathrm{Lig}$ \\
\hline & $\begin{array}{l}\text { Brockton } \\
\text { quarry. }\end{array}$ & $\mathrm{Br}$ & $\begin{array}{l}\text { Light greenish gray with large } \\
\text { pink spots. }\end{array}$ \\
\hline & Hingh & Hinghan & $\begin{array}{l}\text { Light, slightly greenish gray, } \\
\text { seam faces light to medium } \\
\text { brown. }\end{array}$ \\
\hline & $\begin{array}{l}\text { Fitchburg, Rollstone } \\
\text { Hill. }\end{array}$ & & Light to medium bluish gray.... \\
\hline & $\begin{array}{l}\text { Leominster... } \\
\text { Milford....... }\end{array}$ & $\begin{array}{l}\text { Leomi } \\
\text { Milfor }\end{array}$ & $\begin{array}{l}\text { Dark to very dark bluish gray... } \\
\text { Light to medium pinkish or }\end{array}$ \\
\hline & & $\mathrm{U}$ & Light to medium gray...$\ldots \ldots \ldots$ \\
\hline
\end{tabular}

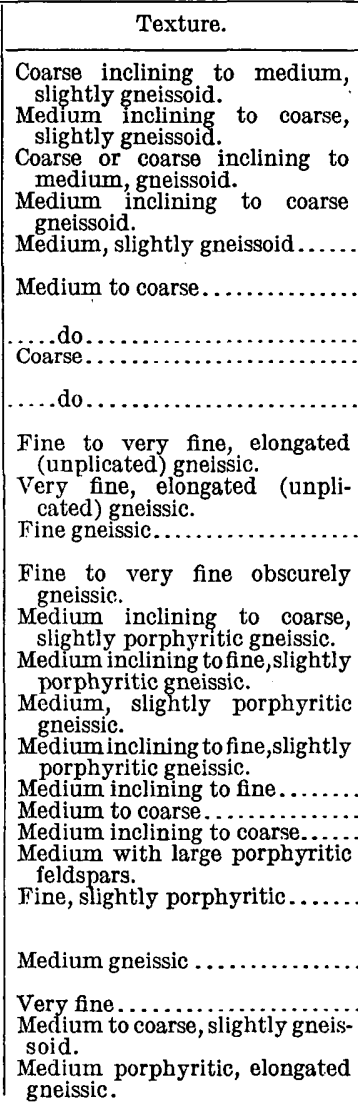

\begin{tabular}{|c|c|}
\hline Petrographic name. & Reference. \\
\hline Biotite-muscovite granite gneiss. & Page 253. \\
\hline .....do. & Page 248. \\
\hline Biotite granite gneiss.. & Page 249. \\
\hline .....do. & Page 249. \\
\hline .....do... & Page 253. \\
\hline Hornblende granite.......... & Bull. 354, pp. 126, \\
\hline Hornblende-augite granite... & $\begin{array}{l}\text { Bull. } 354, \text { p. } 182 . \\
\text { Page 255. }\end{array}$ \\
\hline .....do... & Page 250. \\
\hline Biotite-quartz monzonite gneiss. & Page 258. \\
\hline Biotite granite gneiss. . & Page 261. \\
\hline 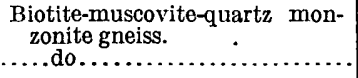 & $\begin{array}{l}\text { Page } 262 . \\
\text { Page } 263 .\end{array}$ \\
\hline Muscovite-biotite granite gneiss.. & Page 264. \\
\hline ..do.. & Page 265. \\
\hline ....do. & Page 266. \\
\hline $\begin{array}{l}\text { Muscovite-biotite quartz mon- } \\
\text { zonite gneiss. }\end{array}$ & Page 269. \\
\hline Biotite-quartz monzonite........ & Page 273. \\
\hline $\begin{array}{l}\text { Riebeckite-ægirite granite......... } \\
\text { Hornblende granite.............. }\end{array}$ & $\begin{array}{l}\text { Bull. 354, p. } 112 . \\
\text { Page 274. }\end{array}$ \\
\hline $\begin{array}{l}\text { Biotite- (or augite) hornblende } \\
\text { granite. }\end{array}$ & Page 275. \\
\hline Aplite....... & Page 276. \\
\hline Muscovite-biotite granite gneiss. & Page 280. \\
\hline $\begin{array}{l}\text { Mica diorite............ } \\
\text { Biotite granite gneiss.. }\end{array}$ & $\begin{array}{l}\text { Page } 283 . \\
\text { Bull. } 354, \text { p. } 75 .\end{array}$ \\
\hline ...do. & Page 283. \\
\hline
\end{tabular}




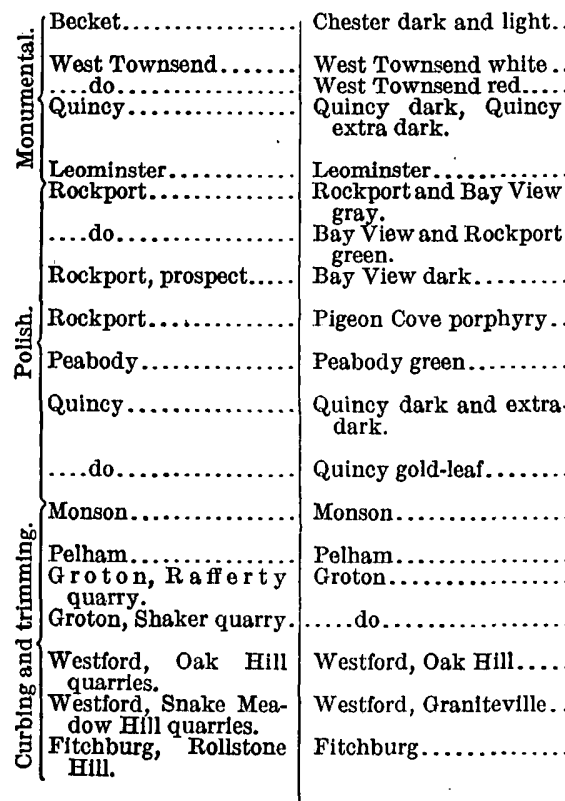

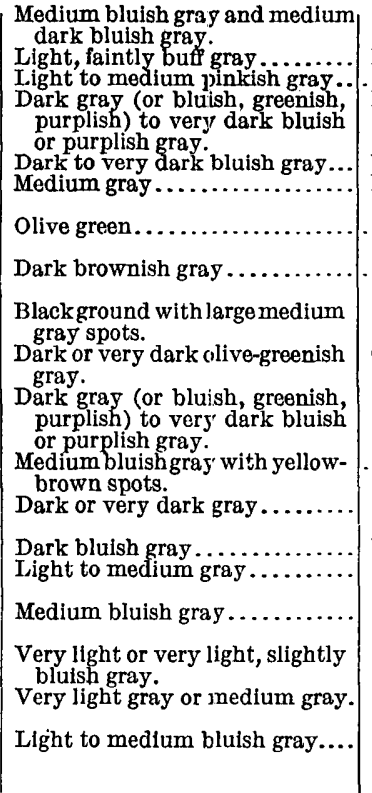

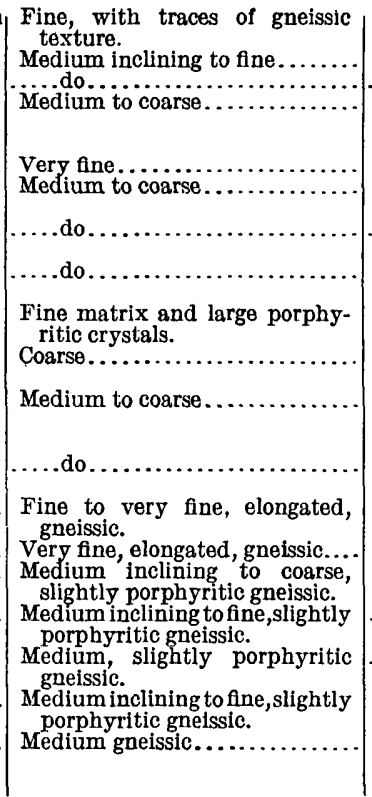

Muscovite-biotite granite....... Biotite-quartz monzonite....... Riebeckite..... Mica diorite Hornblende granite.

....do. .

Riebeckite-ægirite-biotite granite.

phyry.

Hornblende-augite granite.

Riebeckite-ægirite granite.....

Riebeckite-ægirite granite with Biotite-quartz monzonite gneiss.

Biotitegranitegneiss

Biotite granite gneiss.............
Muscovite-biotite granite gneiss.

Muscovite-blotite-quartz monzonite gneiss.
Bull. 354 , p. 141

Page 273.

Bull. 354, p. 191

Page 283. Bull. 354, pp. 186 Bull. 354 , p. 135. Bull. 354, p. 139

Do.

Page 256.

Bull. 354, pp. 107, 109.

Bull. 354, p. 115 .

Page 258.

Page 261.

Page 264.

Page 265.

Page 266.

Page 269.

Page 280. 


\section{MASSACHUSETTS GRANITES IN GENERAL.}

As appears from the foregoing table, the variety of Massachusetts granites is wide considered either scientifically or economically. They include hornblende granites, hornblende-augite granites, riebeckite-ægirite granite, quartz monzonite and quartz monzonite gneisses, biotite granite gneisses, biotite and muscovite granite gneisses, aplite, mica diorite, and diabase porphyry. They vary greatly not only in texture-from granitic to gneissic, coarse to very fine-but also in color and shade-some are pinkish; others peagreenish, olive-greenish, gray of various shades, from light to very dark, besides grays of slight bluish, purplish, or greenish tinge; one is brown.

The most marked for their adaptation are the massive constructional granites of Milford, Fall River, New Bedford, and Rockport; the polish granite of Quincy; the hard paving granite of Rockport; the gneisses for bridges, base courses, curbing, and sills of Monson, Westford, Fitchburg, and Uxbridge; and the Hingham aplite for seam-faced work and for structures in which unusually great crushing or transverse strength are required.

Among the more notable works of Massachusetts granite are the Pennsylvania Terminal in New York and the McKinley Memorial at Canton, Ohio (Milford); the Boston and Baltimore post offices (Rockport); the Army and Navy training stations at Newport, R. I. (Fall River); Bunker Hill Monument, the large polished balls at Rock Island, Ill., and Fairmount Cemetery, Newark, N. J., and the Whitney monument at Woodlawn Cemetery, New York (Quincy). 


\section{SURVEY PUBLICATIONS ON BUILDING STONE AND ROAD METAL.}

The following list comprises the more important recent publications on building stone and road metal by the United States Geological Survey. These publications, except those to which a price is affixed, can be obtained free by applying to the Director, United States Geological Survey, Washington, D. C. The priced publications may be purchased from the Superintendent of Documents, Government Printing Office, Washington, D. C. The annual volumes on Mineral Resources of the United States contain not only statistics. of stone production, but occasional discussions of available stone resources in various parts of the country. Many of the Survey's geologic folios also contain notes on stone resources that may be of local importance.

Alden, W. C. The stone industry in the vicinity of Chicago, Ill. In Bulletin 213, pp. 357-360. 1903. 25c.

BaIN, H. F. Notes on Iowa building stones. In Sixteenth Ann. Rept., pt. 4, pp. 500-503. 1895. $\$ 1.20$.

Burchard, E. F. Structural materials available in the vicinity of Minneapolis, Minn. In Bulletin 430, pp. 280-291. 1910.

430, pp. 292-316. 1910 .

Stone. In Mineral Resources United States for 1909, pt. 2, pp. 569-608. 1911.

Coons, A. T. Slate. In Mineral Resources United States for 1909, pt. 2, pp. 557568. 1911.

DALE, T. N. The slate belt of eastern New York and western Vermont. In Nineteenth Ann. Rept., pt. 3, pp. 153-200. 1899. \$2.25.

- The slate industry of Slatington, Pa., and Martinsburg, W. Va. In Bulletin 213, pp. 361-364. 1903. 25c.

- Notes on Arkansas roofing slates. In Bulletin 225, pp. 414-416. 1904. 35c.

- Note on a new variety of Maine slate. In Bulletin 285, pp. 449-450. 1906. 60c.

- The granites of Maine. Bulletin 313. 202 pp. 1907.

The chief commercial granites of Massachusetts, New Hampshire, and

Rhode Island. Bulletin 354. 228 pp. 1908.

- The granites of Vermont. Bulletin 404.138 pp. 1909.

- Supplementary notes on the granites of New Hampshire. In Bulletin 430, pp. 346-372. 1910.

DALE, T. N., and others. Slate deposits and slate industry of the United States. Bulletin 275. $154 \mathrm{pp}$. 1906 . 15c.

Darton, N. H. Marble of White Pine County, Nev., near Gandy, Utah. In Bulletin 340, pp. 377-380. 1908.

36 pp. 1909.

$94174^{\circ}-$ Bull. $470-11-19$ 
Diller, J. S. Limestone of the Redding district, California. In Bulletin 213, p. 365 . 1903. 25c.

Eckes, E. C. Slate deposits of California and Utah. In Bulletin 225, pp. 417-422. 1904. 35c.

GARDNER, J. H. Oolitic limestone at Bowling Green and other places in Kentucky. In Bulletin 430, pp. 373-378. 1910.

Hillebrand, W. F. Chemical notes on the composition of the roofing slates of eastern New York and western Vermont. In Nineteenth Ann. Rept., pt. 3, pp. 301-305. 1899. $\$ 2.25$.

Hopkins, T. C. The sandstone of western Indiana. In Seventeenth Ann. Rept., pt. 3, pp. 780-787. 1896.

- Brownstones of Pennsylvania. In Eighteenth Ann. Rept., pt. 5, pp. 1025-1043. 1897.

Hopkins, T. C., and Siebenthal, C. E. The Bedford oolitic limestone of Indiana. In Eighteenth Ann. Rept., pt. 5, pp. 1050-1057. 1897.

HuMphrey, R. L. The fire-resistive properties of various building materials. Bulletin 370. 99 pp. 1909.

Keith, A. Tennessee marbles. In Bulletin 213, pp. 366-370. 1903. 25c.

LEIGHTON, HENRY, and BASTIN, E. S. Road materials of southern and eastern Maine. Bulletin 33, Office of Public Roads, Department of Agriculture. 1908. (May be obtained from Department of Agriculture.)

Paige, Sidney. Marble prospects in the Chiricahua Mountains, Arizona. In Bulletin 380, pp. 299-311. 1909.

- Mineral resources of the Llano-Burnet region, Texas, with an account of the pre-Cambrian geology. Bulletin 450. 103 pp. 1911.

Purdue, A: H. The slates of Arkansas. In Bulletin 430, pp. 317-334. 1910.

Ries, H. The limestone quarries of eastern New York, western Vermont, Massachusetts, and Connecticut. In Seventeenth Ann. Rept., pt. 3 (continued), pp. 795-811. 1896.

Shaler, N. S. Preliminary report on the geology of the common roads of the United States. In Fifteenth Ann. Rept., pp. 259-306. 1895.

The geology of the road-building stones of Massachusetts, with some consideration of similar materials from other parts of the United States. In Sixteenth Ann. Rept., pt. 2, pp. 277-341. 1895. \$1.25.

Siebenthal, C. E. The Bedford oolitic limestone [Indiana]. In Nineteenth Ann. Rept., pt. 6, pp. 292-296. 1898.

Sмrт, G. O. The granite industry of the Penobscot Bay district, Maine. In Bulletin 260, pp. 489-492. 40c.

UdDEN, J. A. The oolitic limestone industry at Bedford and Bloomington, Ind. In Bulletin 430, pp. 335-345. 1910.

Watson, T. L. Granites of the southeastern Atlantic States. Bulletin 426.282 pp. 1910.

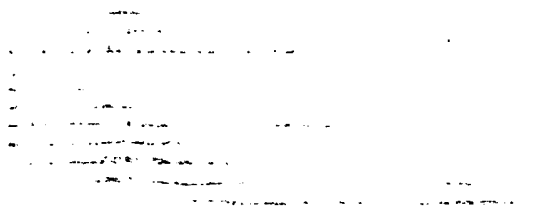




\section{CEMENT AND CONCRETE MATERIALS.}

\section{SURVEY PUBLICATIONS ON CEMENT AND CEMENT AND CONCRETE MATERIALS}

The following list includes the principal publications on cement materials by the United States Geological Survey, or by members of its staff. The Government publications, except those to which a price is affixed, can be obtained free by applying to the Director, United States Geological Survey, Washington, D. C. The priced publications may be purchased from the Superintendent of Documents, Government Printing Office, Washington, D. C.

AdAMs, G. I., and others. Economic geology of the Iola quadrangle, Kansas. Bulletin $238 . \quad 80$ pp. 1904.

BALL, S. H. Portland cement materials in eastern Wyoming. In Bulletin 315, pp. 232-244. 1907.

BAssler, R. S. Cement materials of the valley of Virginia. In Bulletin 260, pp. 531-544. 1905. 40c.

Burchard, E. F. Portland cement materials near Dubuque, Iowa. In Bulletin 315, pp. 225-231. 1907.

Concrete materials produced in the Chicago district. In Bulletin 340, pp. 383-410. 1908.

- Structural materials available in the vicinity of Minneapolis, Minn. In Bulletin 430, pp. 280-291. 1910.

- Structural materials available in the vicinity of Austin, Tex. In Bulletin 430, pp. 292-316. 1910.

The cement industry in the United States in 1909. In Mineral Resources U. S. for 1909, pt. 2, pp. 433-452. 1911.

Butrs, C. Sand-lime brickmaking near Birmingham, Ala. In Bulletin 315, pp. 256-258. 1907.

- Ganister in Blair County, Pa. In Bulletin 380, pp. 337-342. 1909.

Catlett, C. Cement resources of the valley of Virginia. In Bulletin 225, pp. 457461. 1904. 35c.

Clapp, F. G. Limestones of southwestern Pennsylvania. Bulletin 249 . 52 pp. 1905.

CrIDer, A. F. Cement resources of northeast Mississippi. In Bulletin 260, pp. 510-521. 1905. 40c.

- Geology and mineral resources of Mississippi. Bulletin 283.99 pp. 1906.

Darton, N. H. Geology and water resources of the northern portion of the Black Hills and adjoining regions in South Dakota and Wyoming. Professional Papcr 65. 104 pp. 1909.

- Structural materials in parts of Oregon and Washington. Bulletin 387. 36 pp. 1909 .

Cement materials in Republican Valley, Nebraska. In Bulletin 430, pp. 381-387. 1910. 
Darton, N. H., and Siebenthal, C. E. Geology and mineral resources of the Laramie Basin, Wyoming. Bulletin 364.81 pp. 1908.

Duryee, E. Cement investigations in Arizona. In Bulletin 213, pp. 372-380. 1903. 25c.

Eckel, E. C. The materials and manufacture of Portland cement. In Senate Doc. 19, 58th Cong., lst sess., pp. 2-11. 1903.

1904. 35c.

Cement materials and cement industries of the United States. Bulletin 243. 395 pp. 1905. Edition exhausted. Available for reference in libraries of cities and educational institutions.

- The American cement industry. In Bulletin 260, pp. 496-505. 1905. 40c.

- Portland cement resources of New York. In Bulletin 260, pp. 522-530.

1905. 40c.

- Cement resources of the Cumberland Gap district, Tennessee-Virginia. In Bulletin 285, pp. 374-376. 1906. 60c.

Eckel, E. C., and Crider, A. F. Geology and cement resources of the Tombigbee River district, Mississippi-Alabama. Senate Doc. 165, 58th Cong., 3d sess. 21 pp. 1905.

Humphrey, R. L. The effects of the San-Francisco earthquake and fire on various structures and structural materials. In Bulletin 324, pp. 14-61. 1907. 50c.

- Organization, equipment, and operation of the structural-materials testing laboratories at St. Louis, Mo. Bulletin $329 . \quad 85$ pp. 1908.

Portland cement mortars and their constituent materials: Results of tests, 1905 to 1907 . Bulletin $331.130 \mathrm{pp}$. 1908. 25c.

- The strength of concrete beams; results of tests made at the structuradmaterials testing laboratories. Bulletin $344 . \quad 59$ pp. 1908.

99 pp. 1909 .

LANDES, H. Cement resources of Washington. In Bulletin 285, pp. 377-383. 1906. 60c.

Martin, G. C. The Niobrara limestone of northern Colorado as a possible source of Portland cement material. In Bulletin 380, pp. 314-326. 1909.

Pepperberg, L. J. Cement material near Havre, Mont. In Bulletin 380, pp. 327-336. 1909.

Richardson, G. B. Portland cement materials near El Paso, Tex. In Bulletin 3AR, pp. 411-414. 1908.

Russell, I. C. The Portland cement industry in Michigan. In Twenty-second Ann. Rept., pt. 3, pp. 620-686. 1902.

SeweLL, J. S. The effects of the San Francisco earthquake on buildings, engineering structures, and structural materials. In Bulletin 324, pp. 62-130. 1907. 50c.

SHaw, E. W. Gravel and sand in the Pittsburg district, Pennsylvania. In Bulletin 430, pp. 388-399. 1910.

Smith, E. A. The Portland cement materials of central and southern Alabama. In Senate Doc. 19, 58th Cong., 1st sess., pp. 12-23. 1903.

Cement resources of Alabama. In Bulletin 225, pp. 424-447. 1904. 35c.

TAFF, J. A. Chalk of southwestern Arkansas, with notes on its adaptability to the manufacture of hydraulic cements. In Twenty-second Ann. Rept., pt. 3, pp. 687742. 1902. 


\section{CLAYS.}

\section{CLAY NEAR CALHAN, EL PASO COUNTY, COIORADO.}

By G. B. Richardson.

A deposit of clay has recently been exploited near Calhan, El Paso County; Colo., a town on the Chicago, Rock Island \& Pacific Railway 39 miles east of Colorado Springs. The deposit is situated between $1 \frac{1}{2}$ and 3 miles east and south of the railroad station at Calhan. The clay is of good grade, is easy of access, and can readily be worked in open pits.

Calhan is situated near the Platte-Arkansas divide, in the south-central part of a broad syncline known as the Denver Basin. The rocks are all sedimentary, and the strata lie practically flat. Big Sandy Creek has cut down to the coal-bearing rocks of probable Laramie age, which come into contact with the overlying formation in the immediate vicinity of Calhan. The rocks above the coal-bearing strata are composed chiefly of arkose derived from the granite of the Front Range, and the clay deposits constitute a local member of these rocks. They are of Eocene age, but to what subdivision of the Eocene they belong has not yet been determined, although a number of fossil leaves have been collected from them. In an escarpment northwest of Calhan the Eocene rocks are unconformably overlain by conglomerate and sandstone of Oligocene age which contain Titanotherium bones. Southeast of Calhan erosion has carried away the upper beds, and the arkose and associated clays are overlain by unconsolidated gravel and sand, of late Tertiary or Quaternary age, which consitute the surface of the upland for many miles to the south.

The clay occupies a zone about 100 feet thick and outcrops in a northwestward-facing escarpment east and south of Calhan. The deposits are exposed for a distance of 3 or 4 miles, but how far back into the hills they extend has not been determined, although their occurrence probably is not widespread. The clays are stratified and are sorted, water-laid material which apparently accumulated in local bodies of water in contrast with much of the arkose, most of which is of subaerial origin. The composition, occurrence, and asso- 
ciation of the clay indicate that it is slightly transported residual material derived from the decomposition of granitic feldspars.

The clay is varied in texture and color, but development has not gone far enough to indicate the extent of the variations. In texture the clay ranges from extremely fine to coarse grained, and the colors are gray, buff, brown, red, purple, yellow, and mottled. In places it is difficult to get much of any one grade, but selected areas show homogeneous material several feet thick. Apparently little attention has yet been given to sorting the clay at the pits, the material being carted off as it is quarried.

Tests of five specimens of clay selected to represent different grades of the Calhan deposits were made by the Bureau of Standards.

The sample was first ground in a porcelain mortar, then tempered with a sufficient amount of water to render it plastic and molded by hand into small briquets, 3 inches by 1 inch by one-fourth inch. Lines 5 centimeters apart were marked off on the wet pieces by means of a vernier caliper, and from these lines the drying and burning shrinkages were measured. The briquets were dried in the open air. The samples were burned in a down-draft, gas-fired test kiln to $1,210^{\circ} \mathrm{C}$, the duration of the burning being 48 hours. The melting points were determined in an electric furnace, a test cone 1 inch in height serving as the test piece for each clay. 
Tests of five samples of clay from Calhan, Colo.

[By United States Bureau of Standards, Pittsburg laboratory.]

\begin{tabular}{|c|c|c|c|c|c|c|c|c|c|c|}
\hline Sample. & $\begin{array}{l}\text { Color and texture of } \\
\text { raw clay. }\end{array}$ & Molding behavior. & Drying behavior. & $\mid \begin{array}{c}\text { Linear } \\
\text { drying } \\
\text { shrink- } \\
\text { age (per } \\
\text { cent of } \\
\text { wet } \\
\text { length). }\end{array}$ & $\begin{array}{c}\text { Linear } \\
\text { burning } \\
\text { shrink-- } \\
\text { age (per } \\
\text { cent of } \\
\text { dry } \\
\text { length). }\end{array}$ & $\begin{array}{c}\text { Total } \\
\text { linear } \\
\text { shrink- } \\
\text { age (per } \\
\text { cent of } \\
\text { wet } \\
\text { length). }\end{array}$ & $\begin{array}{c}\text { Color burned at } \\
1,210^{\circ} \mathrm{C} .\end{array}$ & $\begin{array}{l}\text { Approx- } \\
\text { imate } \\
\text { melting } \\
\text { point. }\end{array}$ & Chemical analyses. & Remarks. \\
\hline A... & $\begin{array}{l}\text { Fine-textured } \\
\text { light buff. }\end{array}$ & $\begin{array}{l}\text { Plasticit y and } \\
\text { molding proper- } \\
\text { ties suitable for } \\
\text { stiff-mud proc- } \\
\text { ess. }\end{array}$ & $\begin{array}{l}\text { Excell ent; no } \\
\text { warping or } \\
\text { cracking. }\end{array}$ & 6.2 & 8.0 & 14.2 & $\begin{array}{l}\text { Dark buff, pleas- } \\
\text { ing color. }\end{array}$ & $1,630^{\circ} \mathrm{C}$ & 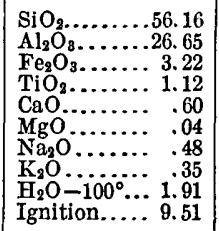 & $\begin{array}{l}\text { Preliminary tests indicate this } \\
\text { clay to be similar to those } \\
\text { used in the manufacture of } \\
\text { buff face brick. }\end{array}$ \\
\hline B... & $\begin{array}{l}\text { Fine-textured } \\
\text { bufl. }\end{array}$ & $\begin{array}{l}\text { Pla a ticity and } \\
\text { molding proper- } \\
\text { ties good. }\end{array}$ & $\begin{array}{l}\text { Excellent; no } \\
\text { warping or } \\
\text { cracking. }\end{array}$ & 5.2 & 7.0 & 12.6 & $\begin{array}{l}\text { Very good red } \\
\text { color. }\end{array}$ & $1,290^{\circ} \mathrm{C}$ & & $\begin{array}{l}\text { A clay which may possibly be } \\
\text { used in the manufacture of } \\
\text { red, common, and face build- } \\
\text { ing brick and drain tile. }\end{array}$ \\
\hline c........ & $\begin{array}{l}\text { Fine-textured } \\
\text { gray. }\end{array}$ & $\begin{array}{l}\text { Plasticity lacking; } \\
\text { not suitable for } \\
\text { stiff-mud man- } \\
\text { facture. }\end{array}$ & & & & $\ldots$ & $\begin{array}{l}\text { Cream - w hite } \\
\text { color. }\end{array}$ & $1,790^{\circ} \mathrm{C}$ & 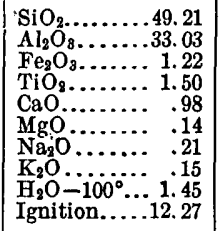 & $\begin{array}{l}\text { Analysis and melting point class } \\
\text { this clay with No. 1 refractory } \\
\text { claps used in the manufacture } \\
\text { of fire brick. }\end{array}$ \\
\hline D. & $\begin{array}{l}\text { Medium-textured } \\
\text { white. }\end{array}$ & $\begin{array}{l}\text { Plasticity good; } \\
\text { molding proper- } \\
\text { ties excellent. }\end{array}$ & $\begin{array}{l}\text { Excellent; no } \\
\text { warping or } \\
\text { cracking. }\end{array}$ & 6.2 & 3.0 & 9.2 & $\begin{array}{l}\text { White burning } \\
\text { cl a y. Ver y } \\
\text { favorable color. }\end{array}$ & $1,750^{\circ} \mathrm{C}$ & 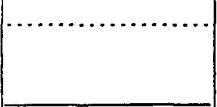 & $\begin{array}{l}\text { Preliminary tests indicate this } \\
\text { clay to be similar to those } \\
\text { used in white-ware manufac- } \\
\text { ture. }\end{array}$ \\
\hline E........ & $\begin{array}{l}\text { Fine-textured } \\
\text { light gray with } \\
\text { streaks of brown. }\end{array}$ & $\begin{array}{l}\text { Plasticity high; } \\
\text { liable to give } \\
\text { trouble in work- } \\
\text { ing. }\end{array}$ & $\begin{array}{l}\text { Excellent; no } \\
\text { warping or } \\
\text { cracking. }\end{array}$ & 8.6 & 4.4 & 13.0 & $\begin{array}{l}\text { L i g h t b u ff. } \\
\text { Color good. }\end{array}$ & $1,670^{\circ} \mathrm{C}$ & & $\begin{array}{l}\text { Probably suitable for a bond clay } \\
\text { in the manufacture of fire } \\
\text { brick, or for the manufacture } \\
\text { of face brick and terra cotta. }\end{array}$ \\
\hline
\end{tabular}


Inspection of the table shows that the Calhan deposits are of good grade clay adapted for various purposes. The plasticity of all the samples except $\mathrm{C}$ is good, and most of the clay, therefore, can be readily molded. Sample $\mathbf{C}$ is not plastic and is what is known as flint clay, which is unsuitable for stiff-mud working. All the samples show excellent drying behavior, neither warping nor cracking. The burning color varies with the iron content. Sample B burns to a good red color; the others burn buff or white, and are therefore valuable for face brick; etc. The fusibility of all is high, that of sample $B$ (the red-burning variety) being the lowest, while that of samples $\mathbf{C}$ and $D$ is very high, classing them with high-grade refractory clays.

Chemical analyses were made of only two samples-A and C. They show that both clays are essentially hydrated silicates of aluminum with small amounts of other substances. The analyses, especially that of sample $\mathrm{C}$, show a close approach to the mineral kaolinite, which is the basis of "pure clay." The sum of the fluxing impurities-iron oxide, lime, magnesia, soda, and potash-is low, indicating high refractoriness. The' notable amount of titanium oxide (more than 1 per cent in each analysis) suggests the presence of rutile, an accessory mineral of granite, which is not uncommon in clays derived from the decomposition of granitic rocks.

Statistics of the quantity of clay mined at Calhan are not available. It is reported that the deposits were first worked in 1903 and that recently shipments have increased. Practically all of the clay is sent to Pueblo, 84 miles distant, where it is reported to be used for making retorts, lining the insides of furnaces, converter bottoms, cupola linings, fire brick for buildings, sewer pipe, etc. 'The Calhan clay is adapted also for the uses suggested by the table of tests. 


\section{CLAY RESOURCES OF THE MURPHYSBORO QUADRANGLE, ILLINOIS.}

By· E. W. Shaw.

\section{INTRODUCTION.}

The Murphysboro quadrangle embraces an area of about 13 by 17 miles, in the southwestern part of Illinois. Its boundaries are parallels and meridians and it includes parts of Jackson and Perry counties. The principal towns are Murphysboro, with 6,463 inhabitants, Ava, and Vergennes. The area is crossed by several railroads and no point in it is more than 6 miles from a railroad track.

The quadrangle lies within a region in which there are extensive clay resources and a large demand for clay products, yet it does not contain many manufacturing plants. Most of the clay deposits of the quadrangle outcrop in a curved belt extending eastward across the south end of the State and northward toward St. Louis, so that the brief description here given' will apply in a general way to a much larger territory.

- More than half of the area included in the Murphysboro quadrangle lies in the great low plain of southern Illinois, but the southwestern part of the quadrangle is within the belt of hills which cross the southern part of the State and are known locally as the Ozarks. The extreme southwest corner includes about 3 square miles of the Mississippi bottoms.

\section{GEOLOGY.}

\section{STRÁTIGRAPHY.}

The strata lying near the surface in the Murphysboro quadrangle consist of more or less consolidated shale, clay, sandstone, limestone, and coal belonging to formations of the Carboniferous system, and unconsolidated clay, sand, and gravel of Quaternary age. A generalized section of the principal groups of strata showing their relation to each other is given below:

Section of rocks in Murphysboro quadrangle.

Quaternary system:

12. Recent alluvium, varying from gravel to clay

Feet.

11. Loess, extremely fine sand

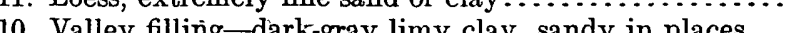

9. Gly fin places...

8. Preglacial alluvium and decayed rock-clay, more or

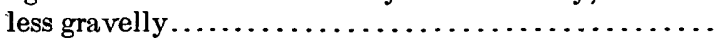


Carboniferous system:

Pennsylvanian series:

Post-Pottsville rocks:

Feet.

7. Coal No. $6 \ldots \ldots \ldots \ldots \ldots \ldots \ldots \ldots \ldots \ldots \ldots . . . \ldots \ldots$

6. Under clay........................... $\quad 0-6$

5. Shale and sandstone, with several lenticular beds of limestone and coal. ............. 175-225

4. Sandstone, soft, micaceous.............. $10-65$

3. Shale, soft, gray, with bed of coal near top... 20-135

2. Coal No. $2 \ldots \ldots \ldots \ldots \ldots \ldots \ldots \ldots \ldots \ldots . . . \ldots . \ldots$

Pottsville formation:

1. Sandstone, hard, gray or buff, mostly massive, nonmicaceous; locally conglomeratic, particularly near the top, and containing lenses of shale and coal at several horizons.......... 400-500

From the above section it will be seen that the Pottsville consists largely of resistant sandstone with a subordinate amount of shale, whereas the higher or younger Pennsylvanian rocks and the Quaternary are composed of softer material, of which clay and shale of various kinds make up a large part.

\section{STRUCTURE.}

The structure of the consolidated rocks is dominated by an uplift in the southwestern part of the area, which gives rise to a general northeast dip and carries the horizon of the top of the Pottsville and coal No. 2 up to 850 feet above sea level in the southwest corner, whereas its altitude in the northeast corner is only 150 feet. The area of greatest uplift is flanked on the east by steeply dipping strata and terminated on the north by a fault of 100 to 200 feet throw. The dips vary from a fraction of a degree to as much as $10^{\circ}$, the steepest dips being found along the eastern and northern borders of the hilly country. The average slope of the strata is 50 to 75 feet per mile to the northeast. The unconsolidated rocks are approximately horizontal, but are more or less confined to certain areas. Some, such as the drift and loess, underlie most of the surface; others, such as the alluvium, are local and irregular in development.

\section{SHALE AND CLAY.}

\section{POTTSVILLE SHALE AND CLAY.}

Considerable bodies of shale and clay are interbedded with the heavy resistant sandstone of the Pottsville formation, and no doubt most of this material is usable at least for the commoner grades of brick, though so far it has not been worked. In general the shale and clay are overlain by sandstone, so that they can not be stripped profitably. It is possible that some of the beds of clay will be found valuable enough to mine. The important clay mined at St. Louis and known by the trade name Cheltenham belongs near the top of the Pottsville, and it is possible that pockets of valuable clay will be found at this horizon in the Murphysboro quadrangle. 


\section{POST-POTTSVILLE SHALE AND CLAY.}

The coal worked at Murphysboro and known as No. 2 is in a few places underlain by plastic clay, but this clay is thin and does not appear valuable enough to warrant exploitation. The under clays of other post-Pottsville coals seem likewise to be of no great value, though locally they may be found worth mining. Up to the present time no tests have been made on these under clays.

Apparently the most valuable and accessible shale in the quadrangle is that overlying coal No. 2. This shale is persistent and appears to be fairly uniform. It is light gray in color, is fairly firm, though it readily becomes soft and plastic on wetting and grinding, and contains scattered iron concretions commonly 3 to 6 inches in diameter. As a rule it contains little quartz sand, but mica flakes are commonly abundant. The thickness of the shale varies from point to point, and this comes about not only through a variation in the thickness of individual beds but through a variation in the character of the upper part of the member. Thus the shale overlying coal No. 2 west of Vergennes is only 20 feet thick and is overlain by a soft massive sandstone. South of this point the sandstone grades into shale, and near Murphysboro there is an almost unbroken mass of shale nearly 100 feet thick, with a thin coal near the top. Ten miles to the north this coal is underlain by the heavy sandstone just referred to.

The value of this shale lies principally in the following properties: (1) It readily becomes fairly plastic, so that it can be molded by the stiff-mud process; (2) it does not shrink greatly on drying and firing; (3) there is a considerable range in temperature between the point at which it begins to fuse and the point at which it becomes viscous; and (4) the burned product has good tensile strength. These characters make it a desirable material for paving brick as well as for common brick and tile. For paving brick and some other products the shale is scarcely as plastic as is desirable, but this can be remedied by the addition of the more plastic loess clay, which is present almost everywhere in this region. Fireproofing requires a very plastic clay, in order that it may pass readily through the peculiarly shaped molds which are used. For this purpose it would probably be desirable to add 75 per cent or more of surface clay, whereas for paving brick 25 per cent of surface clay is found sufficient.

That part of this shale which overlies the thin coal at Murphysboro and lies about 100 feet above coal No. 2 is being worked extensively by the Murphysboro Paving Brick Co. at Murphysboro.

The shale is not valuable enough to warrant underground working and therefore its exploitation will be confined to the area in which it outcrops or lies under thin cover, so that it can be worked by the 
common pit or quarry method. The area of its outcrop is in the form of a strip varying in width from a few feet to 2 miles, extending east from Murphysboro to and beyond the boundary of the quandangle and north from Murphys boro nearly to the northwest corner of Vergennes Township, where it is faulted down to some distance below the surface. Most of the outcrop lies near a railroad.

The group of strata numbered 5 in the generalized section contains several fairly continuous beds of shale which are no doubt usable for the common clay products, but their outcrop is along the eastern and northern borders of the quadrangle 2 or 3 miles from railroads and towns.

The underclay of coal No. 6 is present locally on the eastern and northern boundaries of the quadrangle and it may in places be workable at a profit. There are no known workable bodies of this clay within the area, though it does not lie far below the surface.

\section{QUATERNARY CLAYS.}

The preglacial alluvium is more or less gravelly, and the parts in which clay predominates are deeply buried. The glacial till lies 10 to 30 feet or more beneath the surface and is made up in large part of fine gravel in a clay matrix. Neither of these formations is important as a source of clay.

All the larger streams of the quadrangle once flowed many feet below their present position, but their valleys have been partly filled with fine sediment so that their old channels now lie buried far below the beds where the streams now flow. The original thickness of the filling ranged up to more than 100 feet, but the streams have washed away a part of the material and they now flow about midway between the former upper surface of the filling and their old buried channels. The filling underlies all the low, flat parts of the district, and it is extremely irregular in outline. At Murphysboro it is more than 100 feet thick and consists of yellowish clay containing much fine sand. To the east and north the sand gives place to very fine silt, so fine that much of it will pass through filter paper.

The sandy portion of the valley. filling has been worked at several small pits, such as that in the northeastern part of Murphysboro, where it is overlain by a few feet of loess clay, with which it is mixed. It yields a brick of very good grade. The less sandy portion has, so far as is known, not been tested and the material is not looked upon by practical clay men as very promising for clay manufacturing. However, it is not unreasonable to suppose that it may be a useful and perhaps valuable material to mix with other clays for particular purposes.

Loess.-Under the term "loess" is included all the fine yellowish material which overlies the glacial till and parts of the valley filling. 
With the possible exception of the glacial till this is the most widespread of all the surficial formations, and on account of this wide occurrence and its position immediately below the surface it is the most accessible. It is fairly uniform in physical and chemical characters, though it shows a general variation according to its distance from the Mississippi. That lying near the river is soft, porous, and somewhat calcareous, whereas that 10 to 15 miles from the river is compact, impervious, and noncalcareous-plastic when wet and hard when dry. Ordinary brick has been made successfully from both varieties, though it seems desirable to use an admixture of shale wherever possible.

The recent alluvium is not of great importance as a source of clay. It is of minor extent, is commonly gravelly, and is subject to overflow several times a year. Along the larger streams, however, there are considerable bodies of clay in the "first bottoms."

\section{METHODS OF WORKING.}

Shate.-The only plant at present working shale is that of the Murphysboro Paving Brick Co., about 2 miles north of Murphysboro, which was opened in January, 1909. The pit is located near a small ravine into which surplus water is pumped. The overburden is about 10 feet of sandy clay, which belongs to the valley filling above described. A part of this clay, the lowermost 2 feet, is mixed with the shale in the proportion of 25 per cent of clay to 75 per cent of shale, and the remainder is discarded. The shale is blasted by dynamite and shoveled by hand. The shale and clay are hauled by cable to the plant, where they are ground in a dry pan, wetted, molded, and dried with waste heat. The bricks are then burned for 12 or 14 days in down-draft kilns, coal from a near-by mine being used for fuel.

Clay.- The valley-filling clay is worked at only a few small pits by the ordinary methods of brick manufacture. It would seem, however, that the extensive deposits of clay in the region and the considerable demand for clay products might warrant more extensive exploitation. 


\title{
NOTES ON SOME CLAYS FROM TEXAS.
}

\author{
By Alexander Deussen.
}

\section{INTRODUCTION.}

During the winter of 1909-10 the writer collected about 25 samples of clays from the central Coastal Plain region of Texas, in connection with his work on the stratigraphy and economic geology of this area. Tests on the physical properties and burning behavior of these clays were made in the laboratory of the Survey at Pittsburg, Pa., under the supervision of A. V. Bleininger, ceramic chemist. ${ }^{1}$ A description of these deposits and the results of these tests are presented in this paper.

The area known as the central Coastal Plain region of Texas consists of that portion of the State included between Brazos and San Antonio rivers and between the coast and the Missouri, Kansas \& Texas Railway. Samples were collected from Travis, Lee, Bastrop, Burleson, Washington, and Fayette counties. The location of the deposits is shown on the map (Pl. VI).

In geologic age these clays range from Cretaceous to Pleistocene. The particular formations represented and sampled were the Eagle Ford formation in Travis County, the Taylor marl in Travis County, the Cook Mountain formation in Lee and Burleson counties, the Jackson formation in Burleson and Fayette counties, the Fleming (?) clay in Fayette County, a Miocene clay in Washington County, and Pleistocene deposits in Bastrop County.

The clays include kaolins, brick clays, and fuller's earth. The tests on the clays that give promise for use as fuller's earth are now in progress at the Bureau of Standards, but the results are not yet available for publication.

In Washington, Lee, Fayette, and Gonzales counties occur a series of lenticular, white, kaolin-like clays. These clays have been somewhat extensively advertised as suitable for the manufacture of pottery, porcelain, and chinaware, and some excellent samples of chinaware have been made from the deposits in Fayette County. The results of the tests on these clays have proved more or less disap-

\footnotetext{
'The work of testing structural materials was on July 1, 1910, transferred from the United States Geological Survey to the Bureau of Standards, of the Department of Commerce and Labor.
} 

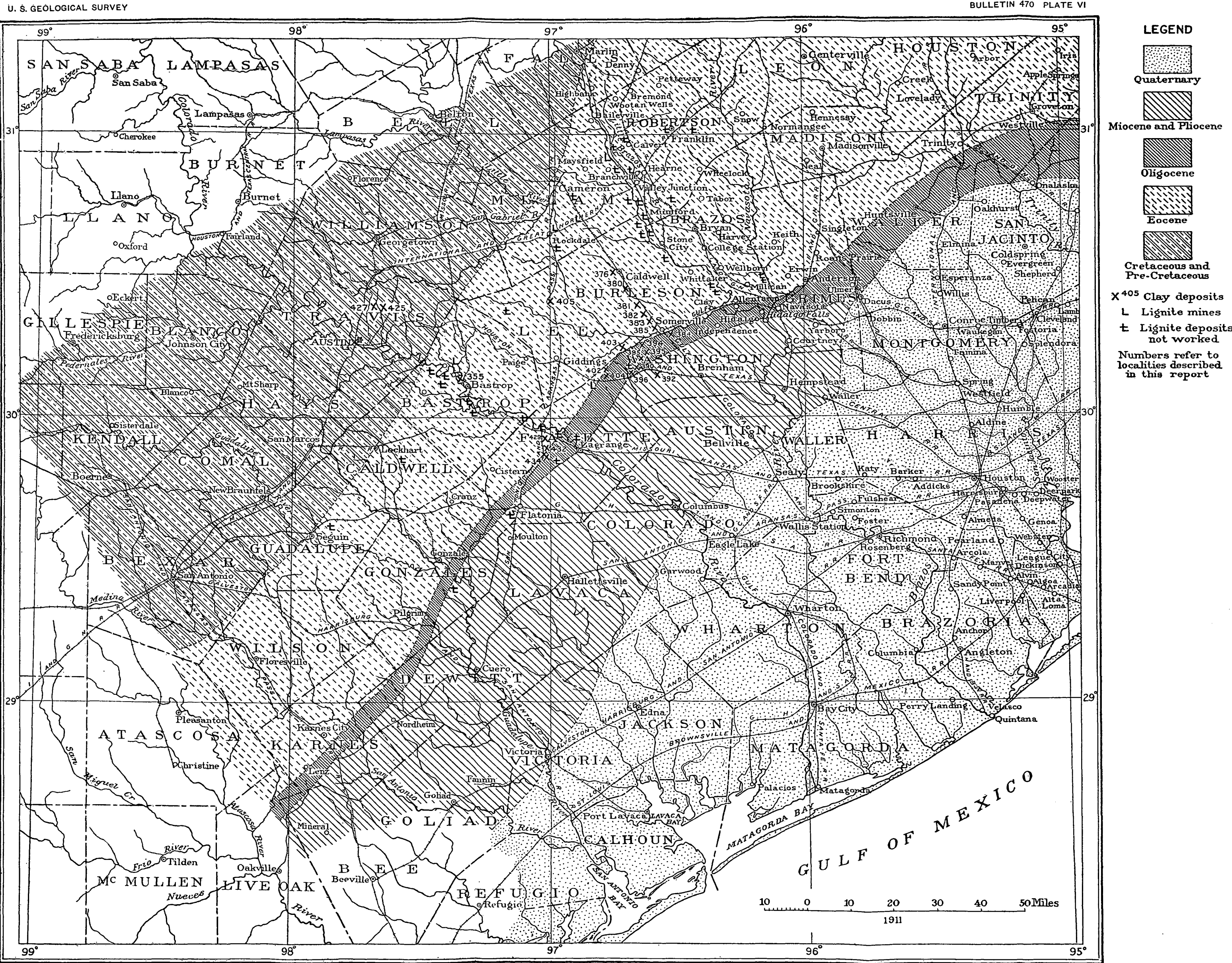

MAP OF CENTRAL COASTAL PLAIN REGION OF TEXAS, SHOWING LOCATION OF CLAY DEPOSITS. 
pointing, and it is extremely doubtful if many of the deposits can be used in the manufacture of clay products of the higher grade. However, these clays might afford suitable material to mix with other clays, so that they might be profitably worked.

It is undoubtedly true that there are in the area from which these clays come some deposits of relatively high-grade fuller's earth that can be worked at a profit. Attempts at development of two such deposits have been made, but both undertakings failed. These failures were due in the first place to improper location of plants and a lack of knowledge concerning the extent and geology of these deposits, and in the second place to the inexperience of the promoters in the manufacture of fuller's earth and the lack of competent business organizations capable of marketing the product. It is believed that in experienced hands, with plants properly located, these clays can be worked at a profit and that they merit additional attention.

\section{METHODS OF INTERPRETING THE REPORTS ON BURN- ING BEHAVIOR AND PHYSICAL PROPERTIES OF THE CLAYS.}

It is desirable to make a few remarks on the methods of interpreting the results of the tests given in connection with the description of the clays.

The particular properties that give a clay value are those that enable it to be molded into any desired form when wet (the property of plasticity), to retain this form permanently, and to become hard when burned. By burning, a clay loses the property of plasticity. These are the two fundamental principles involved in the manufacture of practically all clay products.

A good clay should possess the following properties: When ground and mixed with water, it should be capable of being molded into any desired shape without cracking. Before it can be burned the water used in molding must be given a chance to disappear. In other words, the green wares must be permitted to dry in the air. A clay that does not crack in this process of drying is a good drying clay. A clay must burn to a good, desirable, and uniform color throughout. In addition, it must burn to a condition hard enough to resist abrasion with a knife (steel hard) without blistering, swelling, fusing, warping, or cracking, retaining the same shape in which it was molded, except, perhaps, for a small amount of shrinkage. The most valuable clays are those that retain a perfectly white color even after burning to steelhard condition. These are the so-called kaolins. Clays that will not fuse and get molten or pasty at the highest temperatures to which they may be subjected are known as fire clays.

The steel-hard condition of clay is attained in the burning when some of the more fusible elements of the clay become soft, causing the 
grains to stick together. This is called incipient fusion. All clay products must attain this condition in the process of burning. With a further variable increase in temperature, depending on the character of the clay and ranging from $50^{\circ}$ to $200^{\circ} \mathrm{F}$. or more, most of the particles become sufficiently soft to allow them to settle into a compact, impervious mass, thus closing up all the pores in the clay and decidedly reducing the porosity. This condition is termed vitrification. Practically all the particles have been welded into a dense, solid mass. Up to this point porosity decreases; after this point is reached it increases. Only a few clay products are carried to this temperature or to vitrification, such as vitrified brick, sewer pipe, etc. The porous clay products, such as building brick, earthenware, etc., are carried only to the point of incipient fusion. If the heat is raised beyond the temperature of vitrification, the clay softens, no longer holds its shape, and flows or gets viscous. This condition is called viscosity, or the fusing point. It is needless to remark that this condition must be avoided in the burning of clay products, for if it is reached the wares are lost.

In commercial practice it is not possible to so regulate the heat throughout the kiln that it will everywhere. show the same temperature. Different clays vary in the range of temperature between the points of incipient fusion and viscosity. That clay is most valuable which shows the highest range of temperature between these two points. Some limy clays fuse and become worthless at $50^{\circ} \mathrm{F}$. above the temperature to which they have to be carried to render them steel hard. Some fire clays may be heated $800^{\circ} \mathrm{F}$. above the point at which they become steel hard before they will fuse. It is easily possible to have a difference of temperature of $50^{\circ}$ in different parts of any kiln, the result being that with clays in which the range between the points of incipient fusion and viscosity is at a minimum, a considerable number of the brick will, reach the fusing point and become worthless before the others have reached a temperature high enough to make them steel hard. I.t would not be profitable to work clays of this character in competition with those that would give a larger percentage of perfect brick. For this reason a clay is largely valuable in proportion to the range of temperature between these points.

In the burning of clays any sudden change in the porous condition of the clay (porosity) is always accompanied by sudden shrinkage, which may crack the ware and render it worthless, or by swelling, which will also render the ware worthless. A clay that burns steel hard or to a vitrified condition without warping, cracking, swelling, or blistering, retaining the same form in which it was molded, shows only a small and regular variation in porosity at the different temperatures in the burning process. On the other hand, clays that pos- 
sess these defects and show these faults in burning show also sudden and irregular fluctuations in porosity. The variation and fluctuation in the porosity of a clay at the different temperatures of the burning process therefore form an index to the commercial value of that clay. If the fluctuation is small and regular, the clay is a good clay and well adapted for the manufacture of clay products; if the fluctuation is extreme, rapid, and irregular, the clay is a poor clay and is not adapted for the manufacture of clay products.

Cones are devices to measure the temperature of a kiln at different times and in different portions during the burning process. They are merely thermometers adapted especially to measuring temperature under these conditions. Roughly, the cones indicated in the statements of tests correspond to the following temparatures:

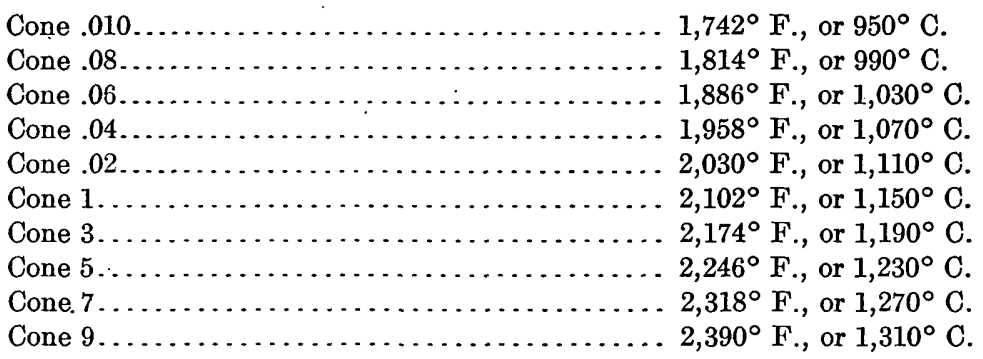

"Porosity at cone 7," therefore, refers to the porous condition of the clay at $2,318^{\circ} \mathrm{F}$. A clay having 70 per cent porosity would be extremely porous, most of its volume being occupied by air space. A clay having 10 per cent porosity would be very compact, with the particles close together and very little air space in its volume.

The tests made on these clays are designed to reproduce identically the processes through which a clay would be carried in manufacture. In other words, the clay is mixed with water, molded, dried in the air, and then burned in a kiln, in order to see how it will behave in these processes. A chemical analysis can not be depended on to afford an idea as to the value of a clay for the manufacture of burned products. The only way to arrive at this is by means of such tests as are above indicated.

In the light of these statements it ought to be easy for even a nontechnical person interested in any particular clay to interpret the tests in such a way that he can form a ready notion of its value for any purpose. For example, as regards molding behavior, clay No. 404 (p. 349) is a good clay, because it molds without tearing or showing lamination, but clay No. 376 (p. 332) is a poor clay, because it tears during the process of molding. As regards drying behavior, clay No. 429 (p. 313) is a good clay, because it does not crack or warp in drying, but clay No. 393 (p. 339) is a poor clay, because it can not be dried without cracking and warping.

$94174^{\circ}-$ Bull. $470-11-20$ 
In drying clays shrink. They show additional shrinkage during the process of burning. As a rule, clays that show high shrinkage in the processes of drying and burning will likewise crack and warp, and vice versa. The shrinkage of a clay may therefore be taken as an index of its value for the manufacture of clay products. The shrinkage may be expressed by comparing in terms of percentage the relation of the length of the dried brick to that of the wet brick. For example, if a brick measures 10 inches in length when wet and 7.5 inches when dry, the shrinkage is 25 per cent. It will be found by an inspection of the tests that a low drying shrinkage is always correlated with good drying behavior, and vice versa. For example, compare clay No. 403 (p. 321), whose drying shrinkage is 2.7 per cent and drying behavior good, with clay No. 382 (p. 337), whose drying shrinkage is as high as 12.41 per cent and all pieces of which warped and cracked in drying.

For reasons above explained, a clay should show little variation in porosity during the different stages of burning, and if variation does occur it should be gradual and not rapid. For example, clay No. 405 (p. 324) burns steel hard without cracking, warping, or blistering, and its porosity at the different temperatures (cones) varies only from 32.60 to 30.30 per cent. On the other hand, in the test of clay No. 385 (p. 318), which fused to a glass and lost the form in which it had been molded, the porosity dropped very suddenly from 48.20 per cent to 0 .

Clays should burn to a red, brown, yellow, cream, buff, or white color, and the coloration should be uniform, although. a speckled color is sometimes desirable. One part should not be cream, another red. Clays that fail to meet these color requirements can not be considered good clays. Again, unless clays will burn to a steel-hard condition, or to the condition of vitrification, practically in the form in which they were molded, without cracking, warping, swelling, or blistering, they can not be classed as suitable for the manufacture of clay products.

To recapitulate, the criteria which must be applied to a clay to determine its value for the manufacture of burned products are the molding properties, drying properties, variation in porosity during burning, color to which it burns, and hardness after burning. For example, compare clay No. 394 (p. 347) with clay No. 382 (p. 337). No. 394 is a valuable clay and could be used in the manufacture of burned products, because it molds without tearing or laminating, dries without cracking, shows a uniform and only gradual variation in porosity during burning, and burns to a fair color and to a steel-hard condition. No. 382 is, when used without mixing with it other material, worthless for the manufacture of burned products, because it molds unsatisfactorily, showing lamination, warps and cracks in drying, and swells 
during burning, its variation in porosity is not uniform nor gradual, and its color after burning is unsatisfactory.

It should be stated that unfavorable properties of one kind and another can often be overcome by the addition of some corrective material to the clay. Whether this can be done at a profit depends on the local conditions, such as the market and the price that can be procured for the products, the availability of the materials to be added, the ease with which they can be worked, and the cost of labor.

The following is the report of A. V. Bleininger, who made the burning and physical tests on these clays:

The clays were tested and their behavior noted as regards the following points:

1. Tempering and amount of water required to produce plasticity.

2. Working quality, degree of plasticity, and ability to flow through an augermachine die.

3. Drying characteristics and drying shrinkage.

4. Behavior in burning as regards progress of vitrification, determination of best burning temperature, burning shrinkage, and relation between burning temperature and porosity.

5. Properties of the burnt specimens, color, hardness, and soundness of structure.

The manipulations carried on in the testing of the clays were as follows:

The sample was first ground (if dry and hard) in a Stevenson pan, then screened on a commercial piano-wire screen, and tempered with the proper amount of water in the pan. The plastic mass was put through a Mueller auger machine and shaped into a bar $3 \frac{1}{2}$ by $3 \frac{1}{2}$ inches, which was cut into briquets $1 \frac{1}{2}$ inches thick. A certain number of these briquets were at once weighed and their volume determined in a Seger volumenometer, petroleum being used as the measuring liquid. The remainder of the test pieces were likewise weighed and then taken into the drying room. Extraordinary difficulties were met in drying many of these samples. It was necessary to remake a number of the specimens once or twice and to dry them under the most favorable conditions in a moist atmosphere, keeping them covered with moist cloths for several days. Yet, in spite of this precaution and even when the briquets were made by hand in brass molds, it was impossible to dry them without their cracking and checking badly. These tests have been made with so much care that there can be no doubt as to the absolute inability of many of these materials to dry satisfactorily under commercial conditions.

So far as possible the volume of the dried specimens was again determined by means of the Seger apparatus and the linear shrinkage calculated, thus insuring maximum accuracy.

The best burning temperature for each test was determined by cutting 12 small briquets, weighing about 100 grams each, out of the larger auger-machine specimens, drying, and firing them in a large gas-fired test kiln to the temperatures stated on page 305. In burning the specimens the cone temperatures were checked by means of the Le Chatelier pyrometer.

The small briquets, after having been burned, were examined for porosity by obtaining their dry weight, their weight after immersion in boiling water and in vacuo, and their weight when suspended in water. The porosity was then calculated from the formula $\mathrm{P}=\frac{\mathrm{W}-\mathrm{D}}{\mathrm{W}-\mathrm{S}} \times 100$, where $\mathrm{P}=$ per cent of porosity, $\mathrm{D}=$ dry weight of test piece, $\mathrm{W}=$ wet weight of test piece, and $\mathrm{S}=$ suspended weight of test piece.

By plotting the porosities against the temperatures the vitrification range of the clays is clearly and definitely determined. It is evident that the more gradual the slope of the curve the longer is the vitrification interval; that is, the safer will the 
product burn under commercial conditions. Owing to the large size of the kiln the rise in temperature was slow, and hence comparable to the conditions of practice. Any clay showing abrupt vitrification under these conditions must be condemned as unsatisfactory for the production of dense hard building brick or other clay wares.

The most favorable burning temperature was thus readily determined, and when it was possible to obtain whole briquets in drying they were burned to this heat.

\section{DESCRIPTIVE NOTES.}

\section{KAOLINS AND KAOIIN-LIKE CLAYS.}

No. 434B. KAOIIN ON IEITENBERG PROPERTY NEAR LENA, FAYETTE COUNTY.

One mile approximately N. $30^{\circ}$ E. from the Lena spur, about 15 miles southwest of Lagrange, on the J. Barton League, and half a mile east of the San Antonio \& Aransas Pass Railway, in Fayette County, occurs a deposit of whitish talclike clay, which may be classed as a kaolin. The location of this deposit is indicated on the accompanying map (Pl. VI) by No. 434. The property belongs to Henry Leitenberg of O'Quinn, Tex.

This clay is exposed in a small ravine, where the following section is visible:

Section in ravine on Leitenberg property.

Feet.

1. Soil and gravel (overburden) $\ldots \ldots \ldots \ldots \ldots \ldots \ldots \ldots \ldots \ldots \ldots, 1$

2. Laminated white clay, with faint streaks of limonite............ 2

3. Hard, dense white "kaolin," breaking with conchoidal fracture, stained and incrusted with limonite on all joint and fracture planes....................................... 3

J. C. Melcher, of O'Quinn, states that in a boring at this point the following beds were passed through below No. 3, of the foregoing section:

Section in boring on Leitenberg property.

Feet. Inches.

4. Red sandstone ............................ 10

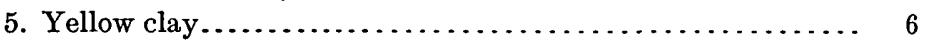

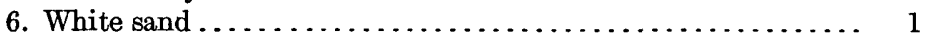

7. Purplish-blue clay ............................ 24

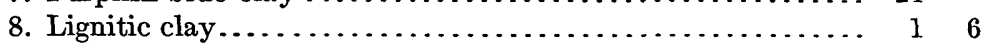

The "kaolin" stratum constitutes the commercially valuable clay at this point. It occurs in the form of a large lens, covering some 40 acres and varying in thickness from 3 feet to a reported maximum of 10 feet. $^{1}$

Borings have been put down on this property in order to ascertain the amount of clay available. The results of these borings have been furnished by Mr. Melcher and are indicated below.

Drill hole No. 27.-This boring was made on the south bank of a small branch, 486 yards east of the railroad and about 500 yards south of the north line of the Leitenberg property. Elevation at surface, 354 feet. (See Pl. VII.) Section shows:

1 The author can not vouch as to the correctness of this figure. No natural exposure occurs which reveals a bed this thick, and no shafts were open that would permit a verification of the statement. 


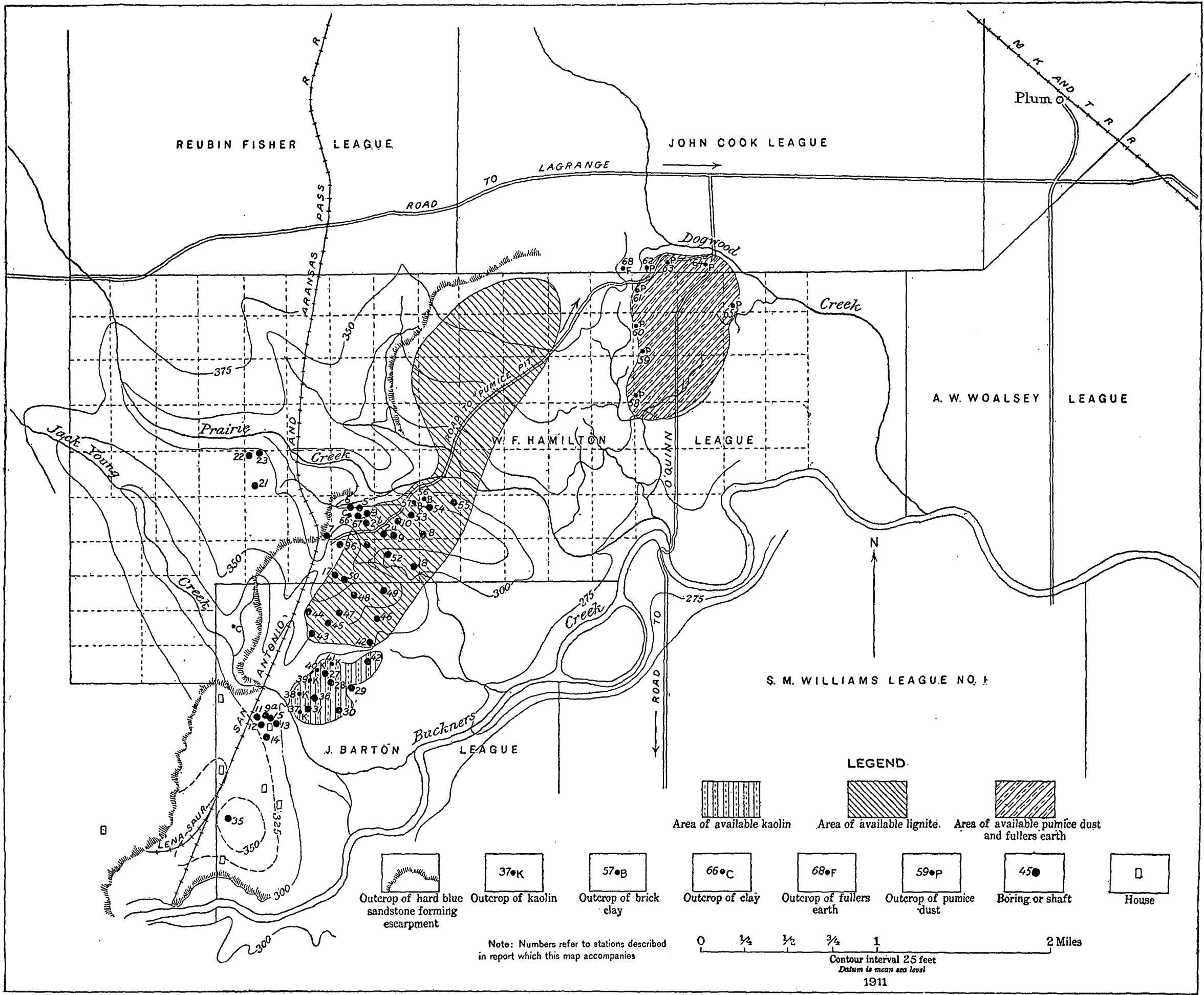

MAP OF CLAY AND LIGNITE FIELDS NEAR LENA, FAYETTE COUNTY, TEX. 
Section in drill hole No. 27.

1. Soil and overburden

Feet.

White clay (kaolin), same as No. 3 of the section on page $308 \ldots$

This white clay outcrops along the branch at this point for a distance of 300 feet.

Drill hole No. 28.-This hole is located 270 feet S. $46^{\circ}$ E. from hole No. 27. Elevation at surface, 356 feet. The section passed through was as follows:

Section in drill hole No. 28.

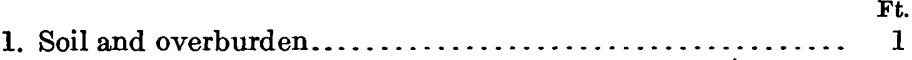

2. Red and yellow clay $\ldots \ldots \ldots \ldots \ldots \ldots \ldots \ldots \ldots \ldots \ldots, 9$

3. Kaolin, same as No. 3 of the section described on page 308 ... $\quad 7 \quad 6$

4. No record ................................. 12

5. Water-bearing sand, carrying good water; entered ....... 1

Drill hole No. 29.-This hole is located 375 feet east of hole No. 28, on the Leitenberg tract of the J. Barton League. The elevation of the surface is 360 feet. No kaolin was found in this hole, indicating that stratum No. 3 of the section described on page 308 pinches out in the direction of the dip, and that this deposit is lenticular.

Drill hole No. 30.-This hole is situated 890 feet S. $15^{\circ} \mathrm{W}$. from hole No. 29. Elevation at surface, 358 feet. Section shows:

Section in drill hole No. 30 .

Ft. in.

1. Soil and overburden.......................... 11

2. Kaolin, same as No. 3 of the section described on page 308 .. 9

Drill hole No. 31.-This hole is located 600 feet S. $10^{\circ} \mathrm{W}$. from hole No. 30, in a ravine where the kaolin outcrops at the surface. This hole revealed the presence of 10 feet of kaolin at this point.

Drill hole No. 32.-This hole is situated 330 feet N. $60^{\circ}$ E. from hole No. 31. It was begun at the butt end of three mammoth petrified trees. No kaolin was found here.

The data indicating the amount of material available and the location of these deposits are shown graphically on figure 43 and Plate VII.

This clay is associated with beds not lower than Jackson nor higher than Fleming. It appears to have been deposited in small erosion hollows or lakes along the seashore in Jackson or Oligocene time. The bed dips slightly to the southeast. The clay is somewhat highly jointed and fractured, the average dimensions of the fragments between the joint and the fracture planes being 2 by 3 by 4 inches. Within the body of the clay each fragment is coated with a film of limonite abont one-thirty-second of an inch thick. When this coat is removed by cutting with a knife, however, the remaining clay contains very little iron.

This deposit is situated in a country that would be classed as poor for agriculture. The topography is sublevel, with here and there small ravines and "washes" along which the clay outcrops. The area is veneered with a thin coat of Pleistocene terrace gravels, made up of quartz, flint, jasper, and limestone cobbles. In places the gravel is overlain by 6 inches to 1 foot of gray to brown clay loam soil referable to the Lufkin soil series as recognized by the Bureau of Soils, and the region is generally covered with a fairly thick growth of post-oak timber. 
The overburden, as indicated by the borings described above, ranges in thickness from 1 foot to 10 feet and will easily average 4 feet over the entire area of 40 acres. This material consists of gray clay soil, 3 to 12 inches of gravel, and in places 2 to 9 feet of white, red, or yellow clay. It is very doubtful if any of this material could be utilized for any purpose, and the removal of 4 feet of overburden would have to appear as a charge of at least 20 cents a ton against the kaolin quarried.

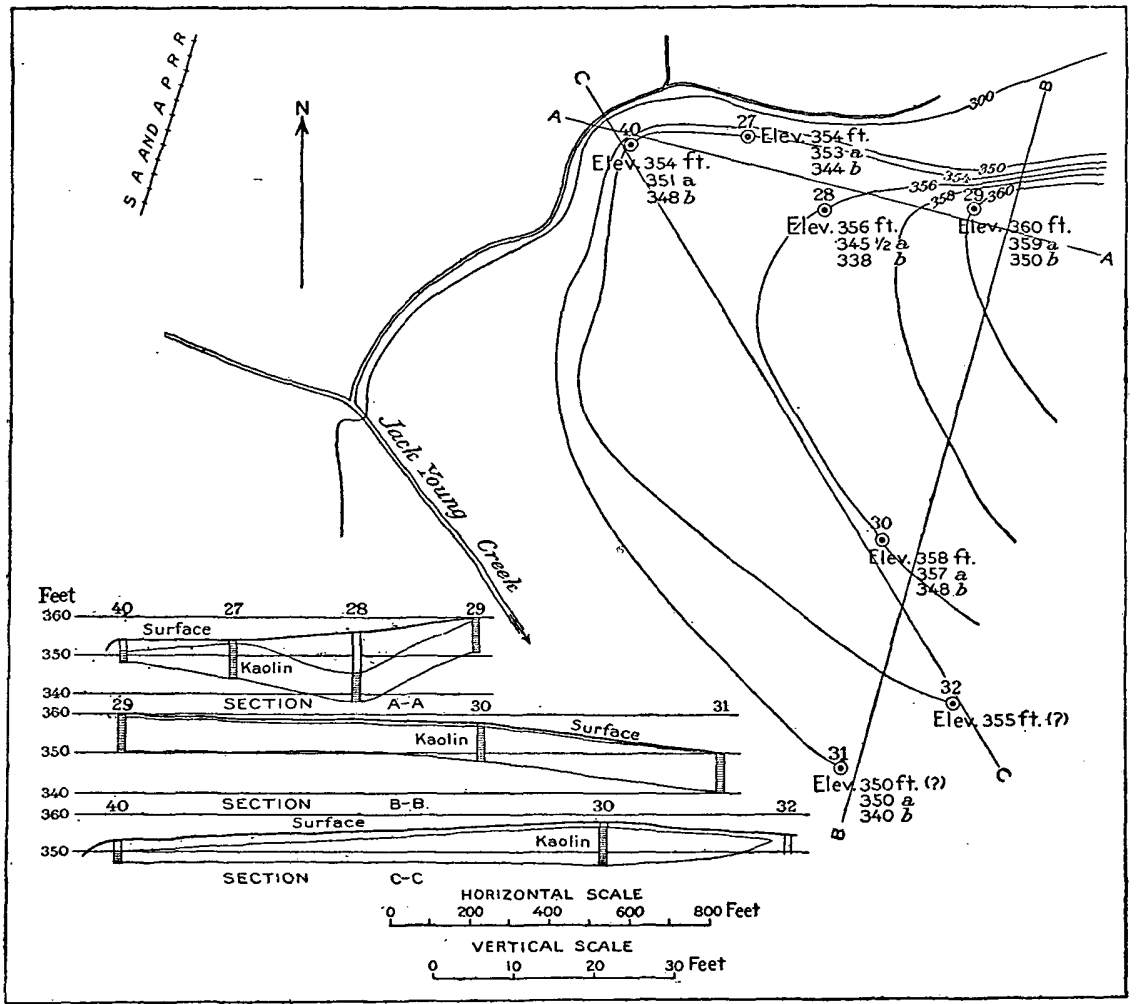

Figure 43.-Map of the vicinity of Lena, Fayette County, Tex., showing lucation of bore holes put down to determine extent of kaolin on Leitenberg property. " $a$ " preceded by number indicates elevation of top of kaolin; " $b$ " elevation of bottom of kaolin. Contours are subject to correction.

On the assumption of an average of 5 feet of kaolin over an area of 40 acres and a specific gravity of 2.5 , about 600,000 tons of kaolin is avajlable in this deposit.

Among the kaolin prospects of Texas this particular deposit is perhaps most favorably situated with respect to transportation facilities. It is located practically adjacent to the Waco division of the San Antonio \& Aransas Pass Railway, and half a mile of spur track would reach the entire deposit. It is but 158.4 miles distant by rail to the seaboard at Galveston, the freight charges to that city being $\$ 1.10$ a ton. The freight charges to Trenton, N. J., are about $\$ 5.90$ a ton. 
Abundant fuel is available in the form of lignite and wood. Lignite mines are operated at Rockdale, in Milam County, 60.4 miles distant on the same railroad, and at Phelan, in the adjoining county of Bastrop, 36 miles distant by rail. A deposit of lignite occurs only 1 or 2 miles north of the clay, but is not worked at the present time. (See Pl. VII.) This deposit is capable of being worked at a profit and doubtless will be mined in the not distant future. Lignite can be laid down at the Leitenberg clay deposit at prices closely approximating $\$ 1.15$ a ton. Good post-oak wood can be delivered at prices ranging from $\$ 3$ to $\$ 3.50$ a cord.

Water satisfactory for steaming and domestic use and in inexhaustible quantity can be had in wells ranging in depth from 100 to 400 feet.

The item of labor will present some difficulty. Negro and Mexican labor will have to be employed, and at best this labor will not be very satisfactory for the peculiar work that this clay will require in preparation. Such labor can be had at prices ranging from $\$ 1$ to $\$ 1.50$ a day.

Clay pits opened at this point will be readily susceptible to drainage by open ditches leading into ravines emptying into Buckner Creek.

This deposit was worked for a brief period in 1908 by the Texas Kaolin Co., whose office was situated at Chicago, Ill. A number of small pits were opened and six carloads of the prepared clay were shipped to the potters in New Jersey. Operations were soon suspended, however, and no work has been undertaken since. The clay was dug out with a pick and shovel, the coating of limonite or iron stain was cut off by hand with a jackknife, and the clay was then crushed to pea size with a hammer, sacked, and shipped. A considerable body of the clay which had been crushed and from which the iron had been removed in the manner above indicated was spread out in a small yard to weather. Some of the material that had been weathered for about a year and a half in this way was sampled and tested to determine its value for the manufacture of clay products. The results of these tests appear below.

Burning behavior and physical properties of kaolin on Leitenberg property near Lena, Fayette County (No. 434B).

Description of raw clay............... Peculiar structure. Amorphous lump surrounded by white bonding material. White, soft.

Molding behavior.................. Good plasticity. Works well in machine. Drying behavior................... Cracks very badly.

Drying shrinkage:

Per cent of wet length........... 8.36

Per cent of wet volume......... 32.8

Burning shrinkage, per cent of wet length. 6.9 
Total linear shrinkage, per cent of wet

length ...................... 15.26

Porosity at cone $010 \ldots \ldots \ldots$ per cent. . 16.4

$.08 \ldots \ldots$......... 7.5

.06 ................ 6.7

$.04 \ldots . . . . . .$. do.... 9.3

$.02 \quad \ldots . . . . .$. do.... 10.2

$1 \ldots \ldots . . .$. . do... 8.2

$3 . \ldots \ldots \ldots . .$. do... 14.2

$5 \ldots \ldots . . . . .$. do... 9.5

$7 \ldots \ldots \ldots \ldots$......... 10.6

$9 \ldots \ldots \ldots . . . .$. do... 11.1

Color after burning................. Good white.

Hardness. . . . . . . . . . . . . . . . . . Steel hard.

Remarks...................... good color holds throughout. Evidence of vitrification at cone 9 . The only clay in the series which is promising as a kaolin.

From these tests it appears that this clay, if mixed with a small amount of corrective material to prevent cracking in drying, would be suitable for the manufacture of white earthenware, chinaware, etc. J. C. Melcher has had some flawless samples of chinaware burned from this clay with an admixture of 75 per cent foreign clay.

It is stated that the clay was prepared ready for shipment as indicated above by negroes and Mexicans at a cost of $\$ 3$ a ton, which included the cost of quarrying, removing the iron, crushing, and sacking. The cost of delivering to the railroad was stated to be 35 cents a ton. The writer has no accurate cost data covering these points, but if these figures are correct, the cost of delivering a ton of this clay to the potters at Trenton, N. J., would be $\$ 12$ a ton, figuring royalty at $\$ 1$, freight at $\$ 5.90$, quarrying, mining, and preparing at $\$ 3$, hauling at 35 cents, bags at $\$ 1$, depreciation at 25 cents, and management at 50 cents. This should allow adequate profits on the mining and shipping of this clay.

It appears that operations were suspended at this point because the potters found that the clay was not adapted to their needs-in what particular way is not apparent. The results of the tests here reported seem to indicate that the only objection that might be offered to this clay is the difficulty experienced in drying it without cracking. The color is good, the clay burns to steel-hard condition without cracking, warping, or blistering, and its fluctuation in porosity is not violent nor extreme. It is hardly probable that the clay was rejected by the potters on account of its poor drying qualities alone, as this defect could be corrected by the addition of quartz sand. It is probable that difficulty was experienced in the burning of the wares and that the colors and hardness proved unsatisfactory. In view of the fact that the results given in this paper were obtained 
on clay that had been weathered for a year and a half, it may be that another trial by the potters on weathered material would give more satisfactory results.

In order to determine if any use could be made of some of the overburden (clay No. 434A) on this kaolin, stratum No. 2 of the section described on page 308 was sampled and its physical properties and burning behavior tested. The results appear below.

Burning behavior and physical properties of white clay on Leitenberg land near Lena (No. 484A).

Description of raw clay.............White, soft laminated clay. Grinds up easily.

Molding behavior.................. Plasticity fair. Good column. No visible lamination.

Drying behavior................... Drying behavior fair. Some cracking on air drying.

Drying shrinkage, per cent of wet volume. 25. 64

Porosity at cone .010........... per cent. . 23.90

.08 .............. do... 11. 20

.06 .................. 0

$.04, .02,1 \ldots \ldots \ldots \ldots$. Glassy structure.

Color after burning................. Pink at the lower temperature, but fades to a buff at the higher temperature.

Hardness. . . . . . . . . . . . . .

Best burning temperature..............

Remarks......................... Nemperature range very short. able for commercial use.

The results of these tests seem to indicate that this material by itself could not be used in the manufacture of clay products, but it may possibly be used as a corrective to be added to other clays that may be burned in this vicinity. In quarrying operations, it would be advisable to keep this material at least separate from the gravel and soil and from other clays that form a part of the overburden.

No. 429. CLAY ON MELCHER PROPERTY, NEAR PLUM, FATETTE COUNTY.

Near the northwest corner of the W. F. Hamilton League, about 3 miles southwest of Plum, Fayette County, at a definite geologic horizon, is found a series of isolated small lenses of massive, soft white siliceous clay that is locally called "pumice dust." The location is more definitely indicated on the accompanying map (Pl. VII, point No. 63). The land on which the clay occurs belongs to J. C. Melcher, of O'Quinn, but leases on it are owned by the Foerster \& Baer Co., 128 Wisconsin Street, Milwaukee, Wis. 
At the point marked No. 62 on Plate VII, at the north line of the W. F. Hamilton League, the following section is exposed:

Section at north line of W. F. Hamilton League.

Pleistocene:

Feet.

1. Gravel, consisting of cobbles and pebbles of flint, quartz, jasper, etc.; suitable for railroad ballast............... 2

Unconformity.

Fleming clay:

2. White siliceous clay, so-called "pumice dust" ......... 3

3. Brown shale or fuller's earth (?) .................... 10

The lateral extent of the clay lens (No. 2 of the section) at this particular point does not appear to be very great, not exceeding 300 feet along the strike line.

Similar lenses are exposed at the same horizon at the points marked $58,59,60,61,63,64$, and 65 on Plate VII, the area in which these lenses outcrop having an average diameter of about three-fourths of a mile. At the point marked 65 a lens 20 inches thick outcrops; at the point marked 64 a lens 2 feet thick outcrops; at the point marked 60 a lens 2 feet 6 inches thick outcrops. Similar lenses also outcrop in Fayette County several miles to the northeast of this locality.

The country here is generally sublevel, dissected in places by ravines and gullies, which would readily permit clay pits to be drained without the aid of pumps. The area is somewhat completely mantled with a deposit of gravel, as described above, that ranges from 6 inches to 2 feet in thickness. Should the deposit be tapped by a railroad spur, this gravel could be marketed as railroad ballast at a price that would at least pay for the cost of its removal.

This deposit is located some 2 miles from the Waco division of the San Antonio \& Aransas Pass Railway, and about $3 \frac{1}{2}$ miles from the main line of the Missouri, Kansas \& Texas Railway. It is doubtful, however, whether the quantity or the value of the material available here would justify the building of a spur to this point.

The conditions as regards fuel, water, and labor for this deposit are identical with those indicated for the kaolin on the Leitenberg property, to the southeast. This siliceous clay is at very nearly the same geologic horizon as the kaolin on the Leitenberg property, though it may occupy a slightly higher stratigraphic position. It appears to have been formed essentially under the same conditions as the kaolin.

This deposit has been worked to a slight extent. Leases have been secured on it by Foerster \& Baer, of Milwaukee, Wis., and some 26 tons of material has been shipped. The clay was merely dug out with pick and shovel at one of the outcrops and hauled by wagon to the shipping point 2 miles distant. It is not being mined at the present time. 
The following are the results of the tests made on this clay to determine its value for the manufacture of clay products:

Burning behavior and physical properties of "pumice dust" near Plum, Fayette County (No. 429).

Description of raw clay.............. White siliceous clay, soft, massive. Grinds up easily in dry pan.

Molding behavior

.Plasticity low. Necessary to mold dry pressed. Very sandy.

Drying behavior Good drying qualities.

Drying shrinkage:

Per cent of wet length........... 0.5

Per cent of wet volume........... .5

Porosity at cone $.010 \ldots . . . \ldots$. per cent.. 50.5

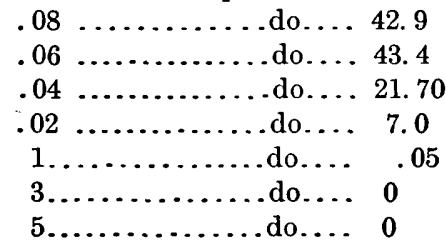

Color after burning Yellowish.

Hardness......................... Vitrifies steel hard.

Best burning temperature..............

Remarks....................... Its poor working qualities and short temperature range do not allow its use in commercial work.

Ries ${ }^{1}$ reports the following as the chemical composition of this clay:

Analysis of "pumice dust" from point near Lena, Fayette County.

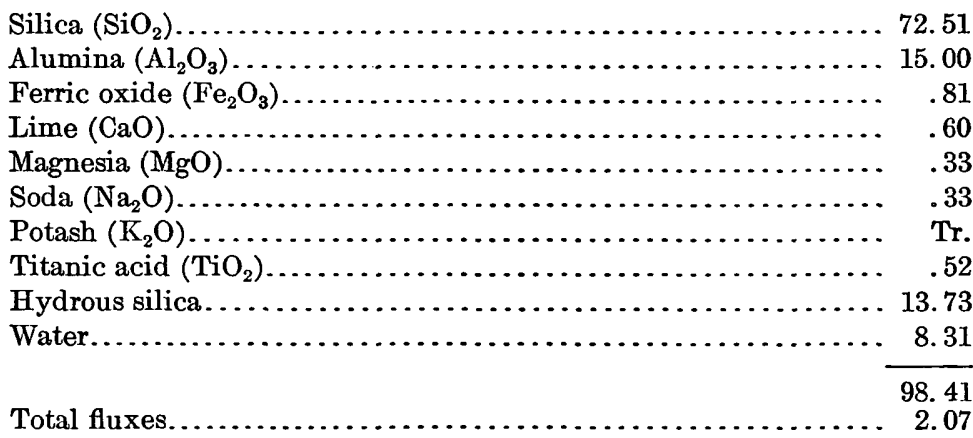

The results of the tests of this material indicate that it is not adapted to the manufacture of any burned products. This is in substantial accord with results obtained by other clay experts and by a number of potters. The material may possibly be used as a corrective to be added to other clays, as an abrasive material, or in the manufacture of white Portland cement. 
No. 390. "KAOLIN" ON TATUM FARM NEAR BURTON, WASHING'TON COUNTY.

About 4 miles northwest of Burton, in Washington County, on the S. O. Tatum farm, in the same geologic formation and apparently at the same horizon as the kaolin on the Leitenberg property, occurs another deposit of white talclike clay, that is locally called a "kaolin." The location of this deposit is shown on Plate VI (point marked 390). The deposit belongs to S. O. Tatum, of Burton.

This clay occurs here as a lens in highly cross-bedded gray sands. At this particular point the lens is 75 feet in diameter along the line exposed to view, and at its thickest point it is 10 feet in vertical extent, but it thins out rapidly on either side. There are probably several of these lenses present at this locality. It is probable that in order to win this clay in the most economical manner the material would have to be mined out.

The clay on freshly broken surfaces has a greenish tint, but when dried out it is perfectly white. No iron stains are visible on the joint and fracture planes. The clay is extensively seamed in all directions, the distance between the seams averaging 2 feet. Along these seams or joint planes no iron discoloration appears.

At the point of exposure the average thickness of the overlying gray sandstones is 3 feet. The material underneath the white clay is a loose porous bluish sand, and there is an erosion unconformity between the overlying white clay and gray sandstones and the underlying bluish sand. Apparently this clay, like the others of similar character, was deposited in an erosion hollow during Oligocene-Miocene time.

The deposit is not very extensive at this point, and it is somewhat doubtful whether there is a quantity sufficient to warrant operations even if the clay were of suitable quality. This is a matter, however, that will have to be determined by careful prospecting.

The accompanying sketch map (Pl. VIII) indicates the general geography in this vicinity and shows the location of certain drill holes and shafts put down to determine the extent of this deposit. In none of these holes was any kaolin struck except in No. 4. 'The record of this boring, as given by Frank Graves, of Burton, indicates that there is present here 27 feet of brown clay or fuller's earth At a depth of 61 feet "kaolin" was met. The clay was not drilled into here because, it is stated, water was encountered.

The country in the immediate vicinity of the outcrop is much dissected into a kind of badland topography. Drainage of open pits could doubtless be easily accomplished. In the interstream areas the country is a sublevel treeless prairie, with a soil of the Houston black clay type. As previously indicated, if a demand should ever develop for this clay it could probably be most profitably won by mining, though the matter of roof would present some difficulty. 


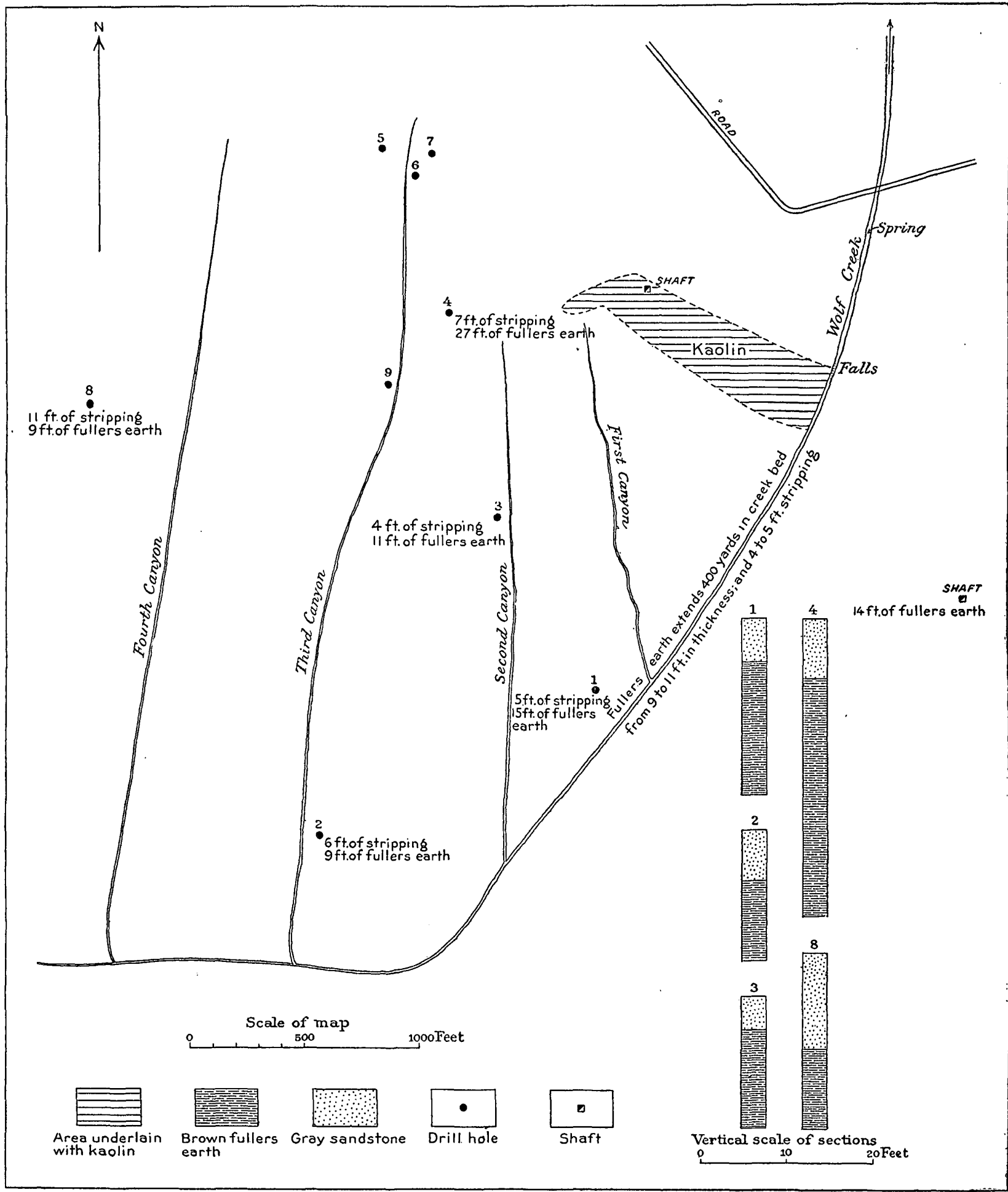

SKETCH MAP OF S. O. TATUM FARM, NEAR BURTON, FAYETTE COUNTY, TEX. 
This deposit lies 2 miles distant from the Austin branch of the Houston \&. Texas Central Railroad. A spur could be easily constructed. For fuel, lignite from the mines at Ledbetter, 7 miles distant by rail, can be had at prices not exceeding $\$ 1.25$ a ton. Cordwood and wood for timbering is available in the immediate vicinity. Water suitable for steaming and domestic purposes can be had in abundant quantity in wells not exceeding 300 feet in depth or from a large perpetual spring within a few yards of the point of outcrop. The labor situation is similar to that indicated for other deposits.

The deposit has not yet been worked, and it is doubtful if its quality is such as to cause any demand for this clay at the present time. The following are the results of burning and other tests made on this clay:

Burning behavior and physical properties of kaolin on Tatum farm near Burton (No. 390).

Description of raw clay................. Massive, fine-grained, tough white clay. Grinds with difficulty.

Molding behavior.................... Plasticity good. Works nicely in machine. No lamination.

Drying behavior. Drying behavior good.

Drying shrinkage:

Per cent of wet length.

Per cent of wet volume............. 21.78

Burning shrinkage, per cent of wet length. 17.70

Total linear shrinkage, per cent of wet

length........................ 24.60

Porosity at cone .010............ per cent. . 32.60

$.08 \ldots \ldots \ldots . . .$. . do... 20.60

.06 .................. .95

$.04 \ldots \ldots \ldots . .$. do... 1.09

$.02 \ldots \ldots \ldots \ldots$. do... 1.6

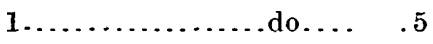

$3 \ldots \ldots \ldots \ldots$............. . 57

5..................... 3.20

$7 \ldots \ldots . . . . . . .$. do... 5.70

Color after burning.................. Buff.

Hardness........................ Soft at cone .010 . Vitreous at cone .06 .

Best burning temperature............

Remarks.......................... Above $1,150^{\circ} \mathrm{C}$. the structure becomes vesicular and at $1,300^{\circ} \mathrm{C}$. the clay is badly swollen. 
The following is an analysis of this clay, made by T. B. Tucker, an advanced chemistry student in the University of Texas:

Analysis of clay from Tatum farm, near Burton.

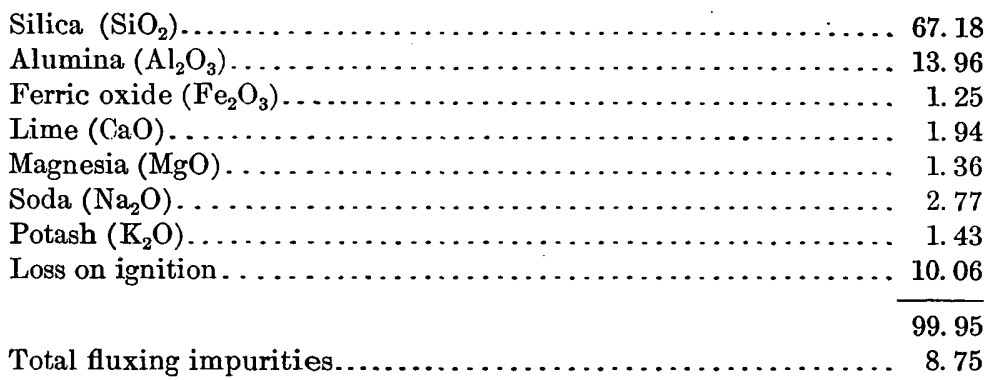

It is apparent from the above analysis that this clay can not be classed as a true kaolin, and it would not by itself be adapted to the manufacture of any kind of pottery or white earthenware.

NO. 385. "KAOIIN" ON BROWN PROPERTY NEAR SOMERVILLE, BURLESON COUNTY.

On the Brown place, 4 miles southwest of Somerville and 1 mile north of the Yegua Creek crossing of the Burton-Somerville road, in the southern corner of Burleson County, occurs another deposit of whitish talclike clay, similar to those previously described. This deposit apparently occurs at a geologic horizon slightly lower than that of the deposits thus far described-in the upper part of the Jackson formation, immediately beneath the hard sandstones of the Catahoula formation and not above them like the kaolin on the Leitenberg property. It is apparently of the same mode of origin, having been deposited in erosion hollows developed during the erosion interval of post-Eocene and pre-Oligocene time.

The country in this vicinity is somewhat hilly and is covered with a veneer of quartz, flint, jasper, and limestone gravel (Pleistocene) averaging 6 inches in thickness. Beneath this occurs some 2 feet of blackclay soil, beneath which in turn is found the so-called kaolin. The thickness of the clay at this point is not determined, but is believed to be not less than 3 feet.

M. M. Graves, of Somerville, states that he has traced this stratum for a distance of three-fourths of a mile by means of borings. The records of these borings are unfortunately not available, and the writer is unable to give positive information on the extent of this deposit.

This deposit is 4 miles distant from the nearest railroad-the main line of the Gulf, Colorado \& Santa Fe Railway at Somerville. For fuel, lignite from the mines at Milano and Rockdale, 33 and 43 miles distant, respectively, by rail, can be laid down at Somerville at prices not exceeding $\$ 1.25$ a ton. Cordwood can be had here at prices 
ranging from $\$ 2$ to $\$ 3$ a cord delivered. Negro and Mexican labor is available at prices ranging from $\$ 1$ to $\$ 1.50$ a day. Water suitable for generating steam can be obtained in wells ranging in depth from 300 to 600 feet.

Below are given the results of burning and other tests made on this clay:

Burning behavior and physical properties of "kaolin" on Brown place, 4 miles southwest of Somerville (No. 385).

Description of raw clay............... Massive, white, medium fine-grained clay. Grinds easily. Has a detritus of hard angular pebbles.

Molding behavior

Plasticity low. Not workable by stiffmud process. Molded dry press.

Drying behavior

Drying behavior good.

Drying shrinkage, per cent of wet volume. . 1.12

Porosity at cone $.010 \ldots . . . .$. per cent. . 48.20

$$
\begin{aligned}
& .08 \ldots \ldots \ldots \ldots \text { do... } 34.60 \\
& .06 \\
& .04 \ldots \ldots \ldots \text { do... } 28.30 \\
& .04 \ldots \ldots \ldots \ldots \text { do... } 0 \\
& .02,1,3 \ldots \ldots \ldots \ldots \text {. } \\
& .
\end{aligned}
$$

Color after burning................. Buff at lower temperature. Brown where vitrified.

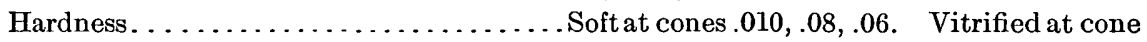
.04 and above.

Best burning temperature. $1,030^{\circ} \mathrm{C}$.

Remarks...................... Nemperature range very short. able for commercial work.

It appears from the tests made that this material is not classifiable as a kaolin, owing to the comparatively low temperature at which it fuses, and it is doubtful if this clay has any commercial value for the manufacture of clay products.

\section{No. 384. "KAOLIN" ON WILLIAMS PROPERTY NEAR SOMERVILLE, WASHINGTON COUNTY.}

On the Williams place, 2 miles southeast of Somerville, in Washington County, occurs another deposit of so-called kaolin, similar in character, origin, and geologic relations to the "kaolins" on the Brown and Tatum properties. Just at this point is situated the northward-facing escarpment formed by the Catahoula formation, which determines the course of Yegua Creek, flowing at its foot. This escarpment rises some 100 feet above the level of the adjacent plain. Immediately underneath the gray sandstones, which form the cap rock of the hills and are, so far as could be determined, about 15 feet thick, occurs a lenticular body of white talclike clay, varying in thickness from 5 to 20 feet. The distance that this deposit extends to the south, in the direction of the dip, is not known, no borings having been put down on it. Along the face of the bluff the outcrop can be traced for a distance of at least one-fourth of a mile. 
The geologic relations of this deposit are very similar to those of the "kaolin" on the Brown property. The deposit occurs in the uppermost portion of the Jackson formation, being apparently unconformable with the formations above and below. Here also the hard sandstones of the Catahoula formation rest directly on top of the clay. Apparently this deposit, like the "kaolin" on the Brown property, was deposited in erosion hollows developed on the land surface of post-Eocene and pre-Oligocene time.

No openings of any kind have thus far been made into this deposit, and no borings have been undertaken to prove its extent. It has therefore not been possible to get a good view of the physical character of the deposit. The fragments detached from the outcrop were generally greenish white in color, but dried out to perfectly white masses. No considerable iron discoloration along joint and fracture planes was apparent.

This deposit lies one-fourth mile east of the main line of the Gulf, Colorado \& Santa Fe Railway and could be readily reached by a spur. It could in all probability be most economically worked by mining, a good roof being present and timber being available for this purpose. The conditions as regards fuel, labor, and water for this deposit are identical with those indicated for the "kaolin" on the Brown property.

Below are given the results of the tests made on this clay:

Burning behavior and physical properties of "kaolin" on the Williams property, 2 miles southeast of Somerville (No. 384).

Description of raw clay............. White, fine-grained, massive clay, with yellow discolorations. Grinds easily.

Molding behavior .Plasticity low. Could not be worked by

Drying behavior stiff-mud process. Made up dry press.

Porosity at cone $.010 \ldots \ldots . . . . . . . . .$. Good

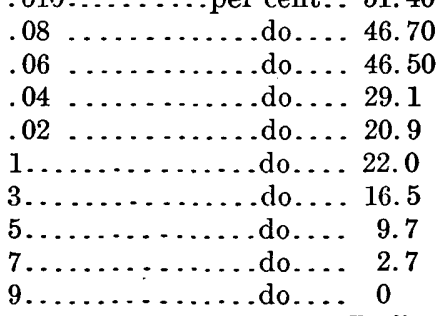

Color after burning................... chuff at lower temperatures, changing to gray.

Hardness.......................... Soft at cones $.010, .08$, and .06 . Steel hard at cone 5 .

Best burning temperature............. $1,230^{\circ} \mathrm{C}$.

Remarks........................... factory color make this clay somewhat undesirable. It has a good temperature range and may be used in the manufacture of dry-pressed bricks. 
It may be that if the iron were removed in a manner similar to that indicated for the clay on the Leitenberg property this clay might find use in the manufacture of clay products of the higher grades. The ease and facility with which it can be worked, the favorable location, and the facilities as regards transportation, market, quarrying, and fuel make it a deposit that merits careful attention. It is possible to quarry and market the overlying rock at a profit in addition to the clay underneath, and the elevated position of these two deposits would make operations of this kind very economical. Natural drainage can be depended on to relieve the pits and quarries of water.

No. 403. "KAOLIN" FROM JOHNSON PLACE, LEE COUNTY.

On the Thomas W. Ward League, $7 \frac{1}{2}$ miles north of Burton, the nearest railroad station, in Lee County, occurs another lenticular mass of white talclike clays, similar to those previously described. The writer has very little first-hand information on this deposit, but the following data have been furnished by M. M. Graves, of Somerville:

The deposit is said to average 10 feet in thickness and to cover some 30 or 40 acres of ground. It is covered with an overburden of soil and gravel that averages 2 feet in thickness. Iron stains or films of limonite appear on the joint and fracture planes.

The available fuel is lignite from the mines at Ledbetter and wood from the immediate vicinity of the deposit. Water can be had in wells not exceeding 500 feet in depth.

The burning tests made on this clay do not indicate that it is of great commercial value, and it is doubtful if it would have any use in the manufacture of clay products. The following are the results of these tests:

Burning behavior and physical properties of "kaolin" on Johnson place, $7_{\frac{1}{2}}$ miles north of Burton (No. 403).

Description of raw clay.............. Soft, white laminated. clay; yellow discolorations along planes of lamination. Grinds easily.

Molding behavior.................. Plasticity low. Clay very short. Did not work well through machine.

Drying behavior.......................

Drying shrinkage:

Per cent of wet length......... 2.7

$\begin{array}{lll}\text { Per cent of wet volume........... } & 6.86\end{array}$

Burning shrinkage, per cent of dry length. 0.9

Total linear shrinkage, per cent of wet

length........................ 3.6

Porosity at cone $.010 \ldots \ldots$. . . per cent. . 45.1

$.08 \ldots \ldots$...... do... 29. 50

$.06 \ldots \ldots \ldots \ldots$. do... 17.9

$.04 \ldots . . . .$. . do... 0

$94174^{\circ}-$ Bull. $470-11-21$ 
Color after burning................ Buff at lower temperatures, changing to salmon at higher.

Hardness. . . . . . . . . . . . . . . . . . . Soft at cones .010, .08, .06. cone .04 .

Best burning temperature.............

Remarks....................... Very short temperature range and poor working qualities render the clay unfit for use.

BRICK CLAYS.

NO. 340. CLAY ON ELLIOTT FARM, WASHINGTON COUNTY.

On the farm of B. F. Elliott on Kerr Creek, and on the J. B. Fryor League in Washington County, occurs a considerable body of green shale that is valuable for the manufacture of building brick. The deposit belongs to B. F. Elliott, of Burton. The location is about 1 mile north of the point marked No. 390 on Plate VI (p. 302).

This deposit is of palustrine origin, having been deposited in a swamp or lagoon adjacent to the shore, apparently in Jackson time.

The deposit is very well exposed in the canyon walls of Kerr Creek on the J. B. Fryor League, where the following section may be seen:

Section in canyon of Kerr Creek.

Ft. in.

1. Brown clay loam soil and subsoil..................... 6

2. Laminated gray sandstone (would form good roof in case this

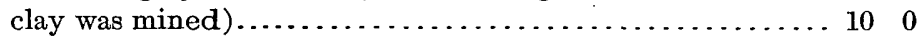

3. Green shale (said to be 11 feet in thickness), exposed ....... 30 $13 \quad 6$

The deposit under discussion (No. 3 of the section) is a hard, finegrained, massive green shale with a pearly luster when wet. The dip of the beds here is slightly to the south.

This shale outcrops along the creek for a distance of 400 yards. It is stated by Frank Graves, of Burton, that this deposit covers some 120 acres of ground. At the point of exposure the overburden is too thick to be removed at a profit, and doubtless the clay could be won more economically by mining than by stripping, but there is some doubt as to whether the value of this clay is such as to justify mining operations. It is probable, however, that by following this clay up the dip it can be found without more than 5 feet of overburden, in a situation where the clay could be handled as easily as at the outcrop mentioned.

The topography in this vicinity varies from sublevel to hilly. The soil is a poor gray sandy soil of the Lufkin and Norfolk soil series, and the country is in places covered extensively with post oak. The deposit is 3 miles distant from the Austin branch of the Houston \& Texas Central Railroad and could be readily reached with a spur. 
The conditions as regards fuel, labor, and water are similar to those indicated for the other clay deposits in the general vicinity of Burton.

This clay may possibly possess value for fuller's earth, though no tests to determine this point have been made. Tests made to determine its burning behavior indicate that this clay may be successfully utilized for the manufacture of building brick. The clay possesses good vitrifying qualities. The following are the results of the tests:

Burning behavior and physical properties of clay on B. F. Elliott farm, near Burton (No. 340$)$.

Description of raw clay

. Hard, fine-grained green shale. Somewhat conchoidal fracture. Grinds easily; no detritus.

Molding behavior.

Plasticity good. Gives fine smooth column on the machine. No visible lamination.

Drying behavior Gives trouble in drying. Pieces used in

Drying shrinkage: volume measurements cracked.

Per cent of wet length.......... 11.95

Per cent of wet volume............ 35.28

Burning shrinkage, per cent of wetlength. 10.40

Total linear shrinkage, per cent of wet

length

Porosity at cone $.010 \ldots \ldots \ldots$ per cent. 23.70

$.08 \ldots \ldots$........ do... 18.40

$.06 \ldots . . . .$. do... 8.9

$.04 \ldots \ldots . .$. do... 8.9

$.02 \ldots \ldots$....... do... 8.9

$1 \ldots \ldots$........... 7.8

$3 \ldots . . . . . . .$. do... 8.2

$7,9 \ldots \ldots \ldots \ldots \ldots$ Melting point not determined. Draw trials checked.

Color after burning................ Buff at cones $.010, .08, .06$; changes to red at higher temperature.

Hardness........................... Steel hard above cone .06 .

Best burning temperature.............

Remarks...................... This clay has a good vitrification and is a promising material for building brick.

Mr. Frank Graves has furnished the following, which is said to be an analysis of this clay made by W. W. Camp, of Denver, Colo.:

Analysis of clay on B. F. Elliott farm, near Burton.

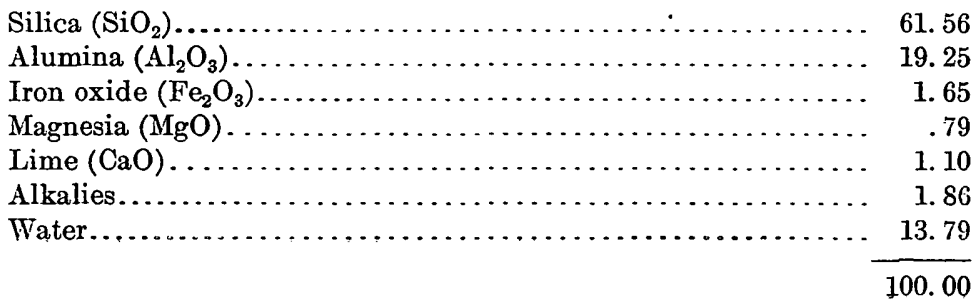


If this analysis is trustworthy, it indicates that this clay would also be valuable for use in Portland cement if there were any limestone in this vicinity that would be suited for this purpose. Unfortunately there is no such limestone near by, but the clay may possibly be utilized in connection with some of the Portland cement limestones that occur 40 or 50 miles to the west of this deposit.

NO. 405. CLAY OF LEXINGTON BRICK \& TILE CO., AT LEXINGTON, LEE COUNTY.

At Lexington, Lee County, a mottled-red, sandy surface clay is manufactured into building brick by the Lexington Brick \& Tile Co. The location of this deposit is marked No. 405 on the accompanying map (Pl. VI, p. 302).

This deposit is the weathered surface clay which represents the altered form of a sandy-clay member of the Cook Mountain formation of the Eocene Claiborne group. The original clay is doubtless of palustrine origin, having been deposited in a swamp near or close to the shore in Cook Mountain time.

In the clay pit at this point there is 5 feet of this mottled-red sandy surface clay. Small concretions of iron and lime about onefourth inch in diameter are fairly well distributed throughout the mass of the clay. Only the surface clay is worked, the underlying clay not being utilized. The deposit covers 5 acres. The overburden consists of a loose sandy soil, 1 foot thick, and is removed by scraping.

The pit is drained by siphoning the water into the adjacent creek, the bed of which lies at a lower level than the bottom of the pit. The pit and plant are beside the Waco division of the San Antonio \& Aransas Pass Railway, the only railroad outlet for this clay. The land here is covered with post-oak timber, which has to be removed in working the clay, but value of the wood pays for the cost of its removal.

Brick has been manufactured here only since the early part of 1910. The clay burns into a red brick, slightly spotted. A system of air-drying only is used. The stiff-mud process of manufacture is employed. The clay is taken from the pit by plows and scrapers and is permitted to weather in the yard for a month or more. After weathering the clay is fed to a pug mill, where it is thoroughly ground and mixed with water, and then it goes to the stiff-mud machine and is pressed into green bricks. The capacity of the machine is 20,000 bricks a day. One "scove kiln" is used for firing. For fuel in the kiln wood is used, which is delivered at the yard at $\$ 2.25$ a cord. For fuel in the power plant to drive the mixing machinery, etc., lignite is used, being delivered from the Rockdale mines at a cost of $\$ 1.13$ a ton. White and negro men are employed at $\$ 1.25$ a day. The bricks as loaded on the cars command a price ranging from $\$ 8$ to $\$ 10$ a thousand. 
This clay is well adapted for the manufacture of building brick. It burns to a good red color, and the temperatures at which the clay becomes steel hard and viscous are well separated, so that there is no danger of overburning some of the brick while the others have not yet attained a steel-hard condition. On the other hand, the clay cracks while drying in air, an undesirable property, and must be dried carefully and slowly in order to avoid this difficulty. The following are the results of the tests in detail:

Burning behavior and physical properties of the clay of the Lexington Brick \& Tile Co. at Lexington (No. 405).

Description of raw clay................. Mottled-red, sandy surface clay, soft. Tempered in wet pan.

Molding behavior................ Very plastic and sticky. Contains fine sand. Works well in machine.

Drying behavior. . . . . . . . . . . . Cracks drying in air.

Drying shrinkage:

Per cent of wet length . . . . . . . 6.7

Per cent of wet volume ......... 20.60

Burning shrinkage, per cent of wet length. 0.53

Total linear shrinkage, per cent of wet

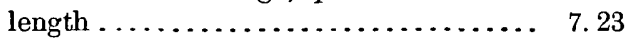

Porosity at cone .010.......... per cent.. 31.8

$.08 \ldots . .$. . . . do... 32.60

$.06 \ldots . . . . . .$. do.... 31.20

$.04 \ldots . . . . . .$. do.... 31.60

$.02 \ldots . . . . . .$. . do... 32.40

$1 \ldots . . . . . . .$. . do.... 31.60

$3 . \ldots . . . \ldots$...... do...: 32.30

$5 \ldots . . . . . . .$. . do... 30.60

$7 \ldots \ldots$.............. 30.30

$9 \ldots \ldots \ldots \ldots \ldots$. . . . . . . 13 .

Color after burning.................. Bood red. Best clay in series.

Hardness. . . . . . . . . . . . . . . . . . Steel hard.

Best burning temperature. . . . . .

Remarks....................... The best red burning clay in the series in regard to color. Requires careful drying. Has a long vitrification range.

No. 392. CLAT ON LAND OF WILLIAM BAUER AT BURTON.

On the land of William Bauer (post office Burton), 125 yards north of the depot at Burton, in Washington County, occurs a considerable body of calcareous clay. The location is shown by No. 392 on Plate VI (p. 302). This clay occurs close to the base of the Miocene beds in this portion of the State. It is apparently of littoral origin, having been deposited in shallow water adjacent to the shore in Miocene time.

This clay is well exposed in the bank of the creek that flows behind the Bauer gin at Burton. This bank shows a deposit of 20 feet of gray, calcareous clay. It is overlain by 2 feet of black clay soil, which would have to be removed in working. This deposit covers 
25 or 30 acres of ground, and over this area at least 20 feet of clay is available.

The country consists of rolling, treeless prairie. Drainage can be secured by a gravity system. Transportation facilities are good, the clay being located alongside the Austin. branch of the Houston \& Texas Central Railroad. For water, impounding reservoirs would most probably have to be constructed, as the well water, which may be obtained here at a depth of 50 feet below the surface, scales the boilers badly. The conditions' as regards labor and fuel for this deposit are identical with those for other clay deposits in the vicinity of Burton.

Burning tests made on this clay indicate that it burns to a good buff color and is suitable for the manufacture of soft building brick. On the other hand, it gives difficulty in drying and would have to be carefully handled. The following are the results of the tests in detail:

Burning behavior and physical properties of the clay on the land of William Bauer at Burton (No. 392).

Description of raw clay.............. Gray calcareous clay; grinds easily.

Molding behavior.................... Good working plasticity; somewhat sandy. Drying behavior................... Volume pieces made in a mold by hand.

Drying shrinkage, per cent of wet length. . 7.56

Warped and cracked in drying.

Porosity at cone .010.......... per cent. . 31.0

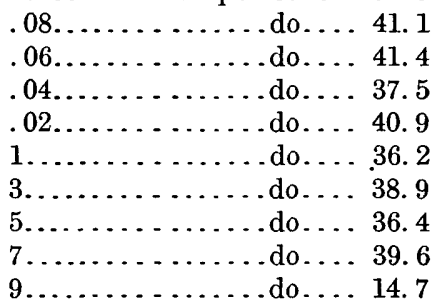

Color after burning................. Good buff from cone .010 to cone 7 . Gray at cone 9 .

Hardness......................... Soft from cone .010 to cone 7 . Steel hard at cone 9 .

Best burning temperature............. $1,300^{\circ} \mathrm{C}$.

Remarks..................... This clay is favorable for soft building brick, having a good color. It has an abrupt temperature range. There is little change in porosity from cone .010 to cone 7 .

No. 425. CLAY ON BIG WALNUT CREEK, TRAVIS COUNTY.

On Big Walnut Creek about 6 miles northeast of Austin, and about one-fourth of a mile north of the Manor-Austin road, occurs a good outcrop of the Taylor marl, the clay of which at this point is suitable for the manufacture of soft building brick. The location is indicated by No. 425 on Plate VI (p. 302). 
In the bluff on the creek at this point there is exposed some 40 feet of calcareous, massive blue shale. This shale is very uniform in chemical and mineralogical composition over a considerable area; the grain is medium fine and the hardness about 2 on the Mohs scale. Back from the top of the bluff there is a somewhat sharp and abrupt slope to the divide, the elevation increasing about 150 feet in a distance not exceeding one-fourth of a mile. This slope, all of which is underlain by the clay, is covered with a veneer of black soil, containing quartz and flint pebbles that average 2 inches in diameter; the average thickness of this overburden is about 2 feet. The slope is covered with a thin growth of mesquite. Altogether 30 to 40 acres of clay is available here that can be worked on a face at least 25 feet in vertical extent.

This locality presents a favorable opportunity for the establishment of a plant where brick can be manufactured very economically. The particular advantages are, first, the great body of clay available of uniform character and under slight cover; second, the ease with which a clay pit could be kept free of water by draining it into Big Walnut Creek; third, the fact that the topography permits the pit to be located on higher ground than the yard, so that clay can be delivered to the yard by a gravity system, loaded cars pulling up the empties; fourth, the excellent transportation and market facilities, this deposit being located alongside the main line of the Missouri, Kansas \& Texas Railway and 2 miles from the Houston-Austin division of the Houston \& Texas Central Railroad; and fifth, the nearness of Austin, a good market town and distributing point for brick.

For water, an impounding reservoir would have to be built. For fuel, lignite would probably prove to be the most economical, supplied by the mines at Phelan, Bastrop County, and Rockdale, Milam County. Labor will cost about $\$ 1.50$ a day.

Burning tests made on this clay indicate that it will burn steel hard at a comparatively low temperature and to a good buff color. Its drying behavior is fair. The details of these tests follow:

Burning behavior and physical properties of clay belonging to the Taylor marl on Big Walnut Creek near Austin (No. 425).

Description of raw clay............... Calcareous blue shale, massive, medium fine grained.

Molding behavior.................... Good working plasticity.

Drying behavior.................... Fair.

Drying shrinkage:

Per cent of wet length............. 10.5

Per cent of wet volume............. 31.20

Burning shrinkage, per cent of wet length.. 4.3

Total linear shrinkage, per cent of wet

length $\ldots \ldots \ldots \ldots \ldots \ldots \ldots \ldots \ldots, 6.2$ 
Porosity at cone $.010 \ldots \ldots \ldots$ per cent.. 22.5

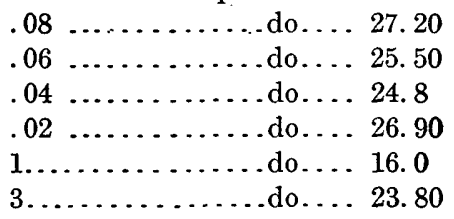

Color after burning.................. Good buff.

Hardness.......................... Steel hard from cone .06 to cone 5 .

Best burning temperature ..............

Remarks...................... This clay is suitable for soft building brick, having a good color.

The following is a chemical analysis of this clay made by the chemical laboratory of the Geological Survey: ${ }^{1}$

Analysis of clay from east bank of Big Walnut Creek $6 \frac{1}{2}$ miles northeast of Austin.

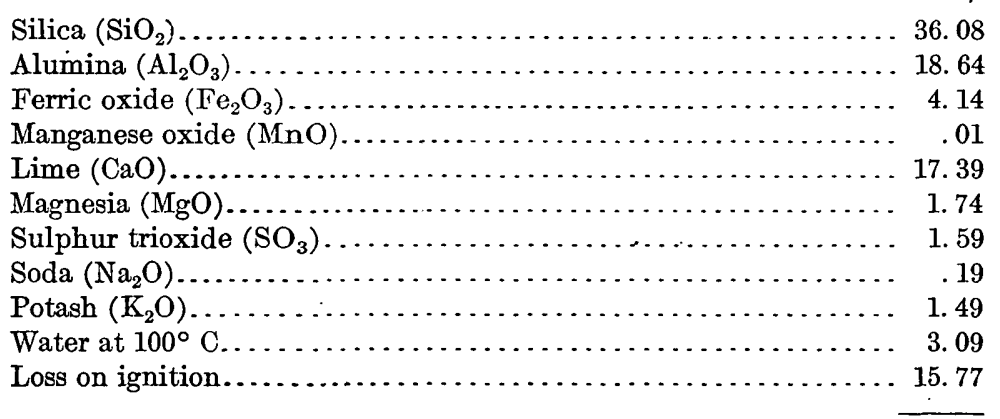

100. 13

No. 427. CLAY AT WATTERS, TRAVIS COUNTY.

Half a mile east of Watters station, on Big Walnut Creek, in Travis County, occurs a good outcrop of shale belonging to the Eagle Ford clay, a formation of the Upper Cretaceous or Gulf series. The portion exposed here represents the upper part of this formation. This shale was sampled in order to determine its value for the manufacture of burned products. The location is shown by No. 427, Plate VI.

This shale is a dark-blue, fine-grained, hard, laminated shale, of marine origin, having been deposited in shoal water in the Cretaceous sea. It carries a slight percentage of bituminous matter. The shale is 15 feet thick and is overlain by 10 feet of limestone gravel.

This shale is very uniform in chemical and physical composition over the available area, which includes some 10 to 20 acres. The working face of the quarry or pit would average 10 feet. The shale is exposed by reason of the occurrence of a small fold which crosses the creek here and which has elevated the clay some 15 to 20 feet above its normal position. Some pyrite nodules are distributed throughout the

\footnotetext{
1 Burchard, E. F., Structural materials available in the vicinity of Austin, Tex.: Bull. U. S. Geol. Survey No. 430, 1910, p. 315.
} 
mass of the shale, but they could be readily removed by hand in quarrying.

The overburden of limestone gravel could be disposed of for railroad ballast or road building at a price that would at least pay the cost of removal. By not working too deep in the clay, water in the pit could be drained into Big Walnut Creek by gravity or by siphoning. The deposit is situated half a mile east of the Llano division of the Houston \& Texas Central Railroad and about $1 \frac{1}{2}$ miles east of the main line of the International \& Great Northern Railroad. At the base of the Eagle Ford formation, at a depth of 40 feet below the bed of the creek, occur some sandy beds which carry a heavy, black asphaltic oil. The wells put down to these beds can be bailed at the rate of 10 barrels a day. It is possible to distill asphalt from this oil, and the fractions could be used as a source of fuel for any manufacturing plant that might be established here. Aside from this possible fuel, lignite and wood are available at prices averaging $\$ 1.25$ a ton and $\$ 3$ a cord, respectively. Labor can be had at prices averaging $\$ 1.50$ a day.

Burning tests made on this clay show it to possess good molding and drying qualities. In addition it burns steel hard and to a good buff color at a reasonably low temperature. However, the range of temperature between the points of incipient fusion and viscosity is lower than is desirable, so that there is danger of overburning and fusing a considerable part of a kiln before the other parts have attained a steelhard condition. For this reason the clay would have to be handled very carefully in burning. The details of the burning tests follow:

Burning behavior and physical properties of clay near Watters, Travis County (No. 427).

Description of raw clay.............. Dark, fine-grained, hard shale. Grinds easily in pan to 10 mesh; no detritus.

Molding behavior Plasticity good; works well on machine; little lamination.

Drying behavior. Good; no warping or cracking.

Drying shrinkage:

Per cent of wet length.............. 6.28

Per cent of wet volume............. 15. 66

Burning shrinkage, per cent of dry length.. 7.9

Total linear shrinkage, per cent of wet

length........................ 14.18

Porosity at cone $.010 \ldots \ldots . .$. per cent. . 63.1

$.08 \ldots \ldots \ldots . .$. . do.... 64.8

$.06 \ldots . \ldots . . . .6$ do.... 64.8

$.04 \ldots \ldots \ldots$. . do.... 59.6

$.02 \ldots \ldots . . . .$. do... 60.6

$1 \ldots \ldots . . .6$. do... 62.3

$3 \ldots \ldots \ldots \ldots$. do..... 58.7

$5 \ldots \ldots \ldots$.......... 21.7

$7 \ldots \ldots \ldots$......... do. 0

Color after burning................... Good buff. 
Hardness Soft until it reaches cone 5 , where it becomes steel hard.

Best burning temperature............. $1,230^{\circ} \mathrm{C}$.

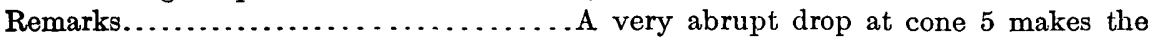
material somewhat unsafe for commercial use.

\section{NO. 380. CLAY ON OPPERMAN FARM NEAR LYONS, BURLESON COUNTY.}

On the Herman Opperman farm, about $2 \frac{1}{2}$ miles north of Lyons, Burleson County, and about one-fourth mile southwest of the main line of the Gulf, Colorado \& Santa Fe Railway, occurs a deposit of green compact shale. This deposit (No. 380, Pl. VI) occurs apparently in the upper portion of the Cockfield formation of the Eocene Claiborne group, close to the base of the Jackson formation.

On a small branch leading into Davidson Creek 6 feet of the shale is exposed, overlain by 2 feet of black clay soil with a small quantity of quartz and flint gravel intermixed and underlain by gray sandstone carrying water. This clay is very uniform in chemical and physical composition and shows no discoloration on the joint and fracture planes, along which water was circulating at the time of the writer's inspection. The hardness is between 2 and 3 on the Mohs scale.

M. M. Graves, of Somerville, has prospected this deposit by means of drill holes, and states that it occurs, in a form similar to that seen on the outcrop, over 30 acres of this farm, varying in thickness from 6 to 7 feet.

The dip of the clay is to the southeast, and in this direction the amount of overburden increases. The average thickness of the overburden over the entire area of available clay is 4 feet. This deposit is very favorably situated with respect to facilities for drainage, transportation, and working. The conditions as regards labor and fuel are similar to those for other clays in the general vicinity of Somerville.

It is thought that this clay may possess value as a fuller's earth (see report on clay No. 381, p. 343) and some tests have been made to determine its bleaching and decolorizing properties. Tests indicate that the clay is only fairly satisfactory for the manufacture of burned products. Great difficulty is experienced in drying the clay, it being found to crack badly. Its burning behavoir is very satisfactory, and perhaps the addition of a slight quantity of sand would correct the poor drying qualities and render the clay useful in the manufacture of dry pressed brick. The results of these tests appear below. 
Burning behavior and physical properties of clay on Opperman farm, $2 \frac{1}{2}$ miles north of Lyons (No. 380).

Description of raw clay............. Green shale, fine grained, massive; ground nicely, no detritus.

Molding behavior. Good working plasticity.

Drying behavior.

All pieces cracked. Volume pieces made in hand mold.

Drying shrinkage, per cent of wet length.. 9.9.

Porosity at cone .010 .......... per cent. . 17.1.

$$
\begin{aligned}
& .08 \text {................. } 5.6 \text {. } \\
& .06 \text {................ } 5.7 \text {. } \\
& .04 \quad \ldots . . . . . . . \text { do... } 3.2 \text {. } \\
& .02 \quad \ldots . \ldots . . . \text {. do... } 6.1 \text {. } \\
& 1 \ldots \ldots . . . . . . \text {. do... } 4.8 \text {. } \\
& 3 \ldots \ldots . . . . . . \text { do... } 3.7 \text {. } \\
& 5 \ldots \ldots \ldots \ldots \text {........ } 4.9 \text {. } \\
& 7 \ldots \ldots \ldots \text {........... } 4.3 \text {. } \\
& 9 \ldots \ldots \ldots \ldots \text { Blue stone, draw trials checked. }
\end{aligned}
$$

Color after burning................ Reddish at cones $.010, .08$, and .06 ; buff at higher temperatures.

Hardness............................... Stemarkable hardness. hard at cones .010 to 7 . Not glassy.

Best burning temperature..............

Remarks.......................... This clay has a remarkable vitrification range, with fairly low porosity; no glassiness. It has poor drying quality; otherwise it would be suitable for brickmaking.

No. 396. CLAY ON JOHN DERRICK FARM NEAR CARMINE, WASHINGTON COUNTY.

About 1 mile north of Carmine, in Washington County, on the farm of John Derrick (post office, Carmine), occurs a considerable body of green calcareous shale that was thought to possess value for the manufacture of burned products. It appears from the results of the tests, however, that this clay is not adapted for the manufacture of such wares, being impossible to dry without cracking. Further, it does not mold satisfactorily and is very unsatisfactory in burning behavior. The location is indicated by No. 396 on the map (Pl. VI).

This clay carries vertebrate fossils of Miocene age. It is evidently of lacustrine origin, having been deposited probably in shallow lakes adjacent to the shore in early Miocene time.

The clay is very well exposed for about a mile in the banks of a small creek that crosses this farm. At one point on the creek there is exposed 10 feet of green calcareous shale. About a mile higher up the creek at the crossing of the Burton-Carmine road, the thickness exposed is estimated at 10 feet and the shale is overlain by 5 feet of brown soil (alluvium).

This shale is of uniform chemical and physical composition throughout. At the surface it weathers into a brown shale; its hardness is about 2 , and it has a pearly luster. 
A considerable body of clay is available here, at least 100 acres. The overburden may average 5 feet, but few data are available on this point. The country is sublevel, cut by canyon-like ravines and covered with sandy soil and post-oak timber. Natural drainage for a clay pit would be available. The deposit could be reached by a spur 2 miles in length from the Austin branch of the Houston \& Texas Central Railroad. The economic conditions governing the exploitation of this deposit-such as the availability and cost of fuel, water, and labor-are in general similar to those indicated for the clay deposits in the vicinity of Burton.

This clay may possibly possess value as a fuller's earth, though no tests to determine this point have thus far been made. The results of the burning tests appear below.

Burning behavior and physical properties of clay on the John Derrick farm, near Carmine (No. 396).

Description of raw clay............... Green calcareous shale. Grinds easily.

Molding behavior.................... Laminated badly; works very poorly on machine.

Drying behavior................... Impossible to dry; cracks and warps badly.

Porosity at cone $.010 \ldots \ldots \ldots$...... per cent. . 25.40.

$.08 \ldots \ldots \ldots . . .$. do.... 19.60

.06 ................. 8.70.

$.04 \ldots . . . . . . .$. do.... 4.80 .

$.02 \ldots \ldots \ldots \ldots$ do............. 3.60 .

$1 \ldots \ldots . . . . .$. do... 4.60 .

$3 \ldots \ldots . . . . .$. do... 4.80 .

$5,7 \ldots \ldots . . . .$. do.... Vesicular.

Color after burning................. Buff at lower temperatures; red at higher temperatures.

Hardness............................ Steel hard from cone .010 to cone 3 .

Best burning temperature............

Remarks......................... Very unsatisfactory as to working behavior, drying, color, and burning. Becomes vesicular above cone2. M zasurement of drying and burning shrinkages not obtainable.

No. 376. SHALE AT CALDWELL, BURLESON COUNTY.

About half a mile south of the courthouse at Caldwell, in Burleson County, occurs an extensive body of gray, very plastic shale. The property belongs to A. B. Duckworth, of Caldwell, and the location is indicated on Plate VI by No. 376.

This shale is a member of the Cook Mountain formation of the Eocene Claiborne group. Its marine origin is proved by the occurrence of marine fossils in the clay.

The clay is well exposed in the banks of erosion hollows on this tract, and its thickness, as shown by these exposures, is at least 10 feet. The clay is available over 4 or 5 acres of ground. In this area 
the overburden, which consists of a reddish-brown clay soil, will average 2 feet.

This shale weathers into a plastic brown clay, the color being due to the oxidation of the iron, which is apparently present in considerable quantity. In the bed sampled the clay was partly weathered and presented a mottled appearance, gray and brown specks making up the mass.

The deposit is 100 yards east of the main line of the Gulf, Colorado \& Santa Fe Railway. A clay pit here could be readily drained by gravity. Water suitable for generating steam can be had in wells not exceeding 300 feet in depth. Lignite can be delivered from the mines at Milano and Rockdale, at a cost not over $\$ 1.25$ a ton. Labor will command $\$ 1.50$ a day.

The results of burning tests made on this clay indicate that it is not well adapted for the manufacture of clay products. It is difficult to mold, warps and cracks in drying, is difficult to oxidize, and burns to an unsatisfactory chocolate color. The details of these tests appear below:

Burning behavior and physical properties of shale on the Duckworth property at Caldwell (No. 376).

Description of raw clay................ Soft, partly weathered gray shale. Grinds easily.

Molding behavior..................... Plastic and sticky. Works poorly on auger machine. Column torn.

Drying behavior...................... Vorps and cracks. Volumeter pieces

Drying shrinkage: cracked. Made up by hand.

Per cent of wet length........... 9.02

Per cent of wet volume........... 36.50

Burning shrinkage, per cent of dry length. . 6.6

Total linear shrinkage, per cent of wet

length ......................... 15.62

Porosity at cone $.010 \ldots \ldots$. . per cent. . 9.3

$.08 \ldots \ldots \ldots$........... 8.4

$.06 \ldots . \ldots . . .$. do .... 7.10

$.04 \ldots . . . . . .$. do... 8.30

$.02 \ldots . . . . .$. do... 5.70

$1 \ldots \ldots$. . . . . do.... 9.50

$3 \ldots \ldots$............. 12.10

$5 \ldots \ldots . . . .$. do... 9.0

$7 \ldots . . . . .$. . do... 0

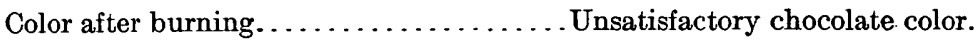

Hardness. . . . . . . . . . . . . . . . . . . Vesicular at cone 1. Steel hard from cone .010 to cone 5 .

Best burning temperature............

Remarks............................. Difficult to oxidize. Has a fairly constant porosity until it reaches cone 1 , when a vesicular structure is developed. 
No. 355. TERRACE CLAY AT BASTROP, BASTROP COUNTY.

Just south of the Missouri, Kansas \& Texas Railway bridge on Piney Creek at Bastrop, Bastrop County, occur terrace clays from which brick were formerly burned. The location of this deposit is indicated by No. 355 on Plate VI (p. 302).

This clay is of alluvial origin, having been deposited by Colorado River in its former flood plain in late Pleistocene times. It represents reworked Permian débris brought down by the river from the Permian area in northwestern Texas. The clay is brown and contains a large percentage of sand, being very lean.

The bluff at this point exposes some 20 feet of this clay. A considerable body of material is available-30 or 40 acres. Owing to the alluvial origin of this clay, it is likely to vary in chemical and mineralogical composition, but within the immediate area observed, where it is exposed along the bluff for a distance of at least half a mile, it appears to the eye to be fairly uniform in physical make-up. Lime concretions appear in it here and there. No overburden need be removed.

A clay pit here could be easily drained by a gravity system. The area is said to be not subject to overflow, and it is apparently well above high-water mark. The deposit is but 200 yards distant from the main line of the Missouri, Kansas \& Texas Railway, and the construction of a siding would be a simple matter. Lignite can be had from the mines at Phelan, 5 miles distant by rail. No timber need be removed. Water can be had from the river and from shallow wells. Labor will command $\$ 1.50$ a day. As a distributing point, however, Bastrop is not to be highly commended.

A small local brick yard was formerly operated here by Al. Jung. The brick burned, as inspected by the writer, were good hard brick of a reddish-yellow color. The brick were burned for local consumption only.

The results of tests on this clay indicate that it molds satisfactorily, dries without cracking, burns steel hard at cone 5 , and burns to a good buff color. On the other hand, the range of temperature between the points of incipient fusion and viscosity is very small, which would result in the overburning of a good many brick in a kiln, so that this clay can not be regarded as suitable for the manufacture of building brick. The details of these tests follow:

Burning behavior and physical properties of alluvial clay at Bastrop (No. 355).

Description of raw clay................ Brown, sandy, alluvial clay; grinds easily. Molding behavior.................. Good working plasticity; sandy.

Drying behavior.................... Very good.

Drying shrinkage:

Per cent of wet length $\ldots \ldots \ldots \ldots \ldots \quad 3.96$

Per cent of wet volume . ......... 14.26

Burning shrinkage, per cent of dry length.. 0 
Total linear shrinkage, per cent of wet

length......................... 3.96

Porosity at cone .010......... per cent.. 49.20

$.08 \ldots \ldots \ldots \ldots$. do... 42.20

$.06 \ldots \ldots$.......do... 42.80

$.04 \ldots . . . .$. ... do... 34.80

$.02 \ldots . .$. .... do... 43.00

1............. do... 42.30

3............ do... 40.70

$5 \ldots \ldots \ldots . .$. . do... 0.4

$7 \ldots \ldots$........... do... Fusing.

Color after burning.................. Good buff.

Hardness....................... Soft from cone .010 to cone 3 ; steel hard at cone 5 ; vesicular at cone 7 .

Best burning temperature.............. $1,170^{\circ} \mathrm{C}$.

Remarks....................... ing behavior and a fine color, but the sudden drop in porosity between cones 3 and 5 would be unfavorable for working in commercial kilns.

No. 402. CLAY NORTHEAST OF LEDBETTER, IN WASHINGTON COUNTY.

On the Burkhart land, $2 \frac{1}{2}$ miles northeast of Ledbetter, in Washington County, occurs an extensive deposit of soft, white laminated clay (No. 402, Pl. VI). This clay is apparently of palustrine origin, having been deposited in a swamp adjacent to the shore in Jackson time. The deposit appears to be much more extensive than the others of similar nature in this region.

On the headwaters of Turkey Creek the following section is exposed in the bank of the creek:

Section on Turkey Creek $2 \frac{1}{2}$ miles northeast of Ledbetter.

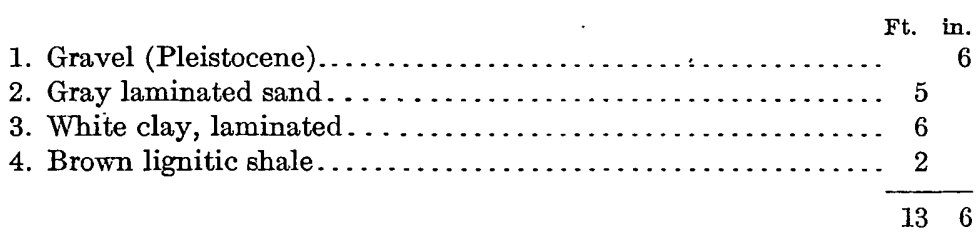

The clay (No. 3 of the section) is soft, its hardness being about 1.5 on the Mohs scale. On the face of the bed there is a slight tint of yellow discoloration, indicating the presence of iron. Otherwise the clay appears to be of uniform chemical and physical composition over a considerable tract of land.

A deposit of identical character, 7 feet thick, was found at a depth of 30 feet in the shaft at the lignite mine near Ledbetter, 2 miles west of this point. J. W. Hackworth, of Ledbetter, informs the writer that in the shafts put down to determine the extent of the lignite which underlies the white clay in this vicinity a similar bed of clay was passed through. Apparently, therefore, this clay covers an 
extensive area, but it doubtless lies under too heavy a cover to be valuable over all of this area. Doubtless, however, a tract can be located in which the overburden should not average more than 5 feet in thickness and will consist chiefly of gravel, which can be used for ballast, and clay.

The general geographic, physical, and economic conditions for this deposit are similar in all respects to those outlined for clay No. 404 (p. 349).

Tests were made to determine the value of this clay for the manufacture of burned products, but the rapidity with which it fuses and its low plasticity would seem to render it unsuitable for commercial work. The results of these burning tests appear below:

Burning behavior and physical properties of clay on the Burkhart land, $2 \frac{1}{2}$ miles northeast of Ledbetter (No. 402).

Description of raw clay.............. Soft, white laminated clay; grinds easily.

Molding behavior................ Very low plasticity and short; column torn at corners.

Drying behavior Good.

Drying shrinkage:

Per cent of wet length........... 6.35

Per cent of wet volume......... 18.58

Burning shrinkage, per cent of wet length 19.20

Total linear shrinkage, per cent of wet

length..................... 25.55

Porosity at cone $.010 \ldots . . . .$. per cent. . 39.4

$.08 \ldots \ldots$. . . do... 31.7

$.06 \ldots . .$. . . do... 17.4

$.04 \ldots . .$. . . do.... 0.3

$.02 \ldots \ldots$........... 0

$1 . \ldots \ldots \ldots$......... 0

Color after burning................. Buff.

Hardness.......................... voft at cones $.010, .08$, and .06 : vitreous above cone .04 .

Best burning temperature............ $1,070^{\circ} \mathrm{C}$

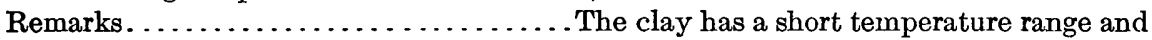
would be unsuited for commercial work of any kind. All draw trials from cone .06 to cone 7 were shattered in being drawn from the kiln.

NO. 375. CLAY NORTHWEST OF CALDWELL, BURLESON COUNTY.

Three-fourths of a mile northwest of the courthouse at Caldwell, Burleson County, occurs a deposit of residual weathered sandy clay, from which brick have been burned for local use at Caldwell. The clay is a surface clay derived from the underlying Cook Mountain formation, the particular member occurring here being a red sandy clay, probably of palustrine origin. This surface clay is 6 feet thick over an area estimated at 15 acres. It is covered with a foot of sandy 
soil, which supports a thin forest of post oak. So far as could be ascertained the material is fairly uniform in chemical and physical composition. A pit here could be drained without pumping. The deposit lies half a mile east of the main line of the Gulf, Colorado \& Santa $\mathrm{Fe}$ Railway, and could be readily reached with a spur. The situation as regards fuel, labor, and water is similar to that of the other deposit near Caldwell, described above.

Tests indicate that this material is not classifiable as a clay because it will not mold, being too high in sand, and because it can not be burned to a steel-hard condition. The material may be useful as a molding sand, but no tests have been made to determine its value for this purpose. The results of the burning tests appear below:

Burning behavior and physical properties of clay northwest of Caldwell (No. 375).

Description of raw clay............... Brown sandy clay; friable.

Molding behavior................. Not a clay; similar to molding sand; made

Drying behavior. up in hand molds.

Porosity at cone $.010 \ldots . . .$. . per cent.. 35.60

$.08 \ldots . . .$. . do... 36.30

$.06 \ldots . . . .$. do... 36.30

$.04 \ldots . .$. .... do... 36.40

$.02 \ldots \ldots$.......... do. 35.90

1 . ............ do... 36.20

$3 \ldots$.............. 36.50

$5 \ldots$......... do... 35.40

$7 \ldots \ldots$........ do... 35.10

Color after burning..................

Hardness. . . . . . . . . . . . . . . . . Soft.

\section{FULLER'S EARTH.}

NO. 382. CLAY FROM PIT OF SOMERVILLE FULLER'S EARTH PLANT.

Three miles north of Somerville, Burleson County, and 1 mile west of the main line of the Gulf, Colorado \& Santa Fe Railway, is located the plant and clay pit of the Somerville Fuller's Earth Co. (No. 382, PI. VI). In the pit there is exposed some 12 feet of brown fuller's earth, which dips beneath hard gray sandstones not over 200 feet from this point. Geologically this fuller's earth occurs in the upper portion of the Jackson formation.

This deposit is known to cover some 50 acres and is available over all of this area. It has been carefully prospected and surveyed, but the results of the borings are not known. Over most of this area the clay is covered with 3 to 10 feet of brown loamy soil and gravel, which in some places is underlain by a gray sandstone on top of the fuller's earth.

The fuller's earth itself is a fine-textured, compact, even-grained, hard brown clay, with hardness varying between 2 and 3 on the Mohs $94174^{\circ}-$ Bull. $470-11-22$ 
scale. The bed dips slightly to the south. Joint and fracture planes are numerous and along these planes, as well as the lamination planes, there is visible a slight coating of limonite, deposited by the action of circulating water. The clay also contains a few nodules of pyrite averaging three-fourths of an inch in diameter.

The topography in this vicinity is generally sublevel, though there are some ridges and hills formed by the relatively hard gray sandstones. Most of the area is covered by a veneer of the Pleistocene terrace gravels, made up of quartz, flint, jasper, and limestone cobbles and pebbles. . In places this gravel is covered by a plastic brown clay-loam soil of the Lufkin soil series. The region is generally forested with post oak.

For fuel, lignite from the mines at Milano and Rockdale is available, as well as the cordwood that can be cut in this vicinity. Water satisfactory for steaming can be had in wells not exceeding 500 feet in depth. Natural drainage can be depended on to keep the pits free from water.

This deposit was worked for a brief period in 1909 and 1910, the clay being manufactured and marketed as fuller's earth. An $\$ 80,000$ plant was erected here in 1909 , but it proved a failure. The clay was dried and then crushed to a fineness of 80 to 200 mesh. It is asserted that one of the causes of failure was that the company was preparing too fine a product, earth of 90 mesh being the grade that is commonly used in bleaching or decolorizing ordinary oils. Another disadvantage was the lack of a spur connecting the plant with the railroad, so that the prepared earth had to be hauled by wagon 3 miles to the nearest shipping point. Under these circumstances, it cost about $\$ 14$ a ton to deliver the fuller's earth in Chicago. The market price in Chicago varies from $\$ 14$ to $\$ 18$ a ton. Under favorable working conditions, on a deposit properly located and with adequate shipping facilities, this earth could probably be delivered in Chicago at $\$ 10$ a ton.

Mexicans and white men were employed as hands at a cost of $\$ 1.50$ a day. The quarrying methods were very simple. The clay was dug with picks, shoveled into wagons, and then hauled to the mill, about 700 feet distant from the pit. It cost $\$ 1.50$ a ton to haul the prepared earth from the mill to the cars. The freight rate to Chicago is $\$ 6.75$ a ton. Twenty per cent of the net proceeds was paid to the owners of the land as a royalty. The capacity of the plant was one-third of a car, or 6 tons, a day.

After the shipment of a few cars of the earth, which it was found very difficult to market, work was discontinued and the plant is now idle. If the earth had been properly bolted and the finer material separated from the coarser in a way to suit the demands of the trade, it would doubtless have found a ready market. It is believed that 
if plants are located properly and intrusted to experienced men, these deposits can be profitably worked.

The Survey has not yet completed any tests to determine the value of this clay when used as fuller's earth, but such tests are now in progress, and the results will be available for publication sometime during the present year. Tests were made on this clay to determine its burning properties, but the results seem to indicate that it has no value for the manufacture of burned products.

Burning behavior and physical properties of clay at Somerville fuller's earth plant, 3 miles north of Somerville (No. 382).

Description of raw clay............... Light-brown, fine-grained shale. Grinds easily with no detritus.

Molding behavior.................... Fuller's earth. Extremely plastic and sticky. Works unsatisfactorily in machine. Laminated structure.

Drying behavior . . . ............... All pieces warped and cracked; pieces made

Drying shrinkage: by hand cracked.

Per cent of wet length.......... 12.41

Per cent of wet volume.......... 38.30

Burning shrinkage, per cent of dry length. . 5.7

Total linear shrinkage, per cent of wet

length...................... 18.11

Porosity at cone $.010 \ldots \ldots \ldots$. per cent.. 21.3

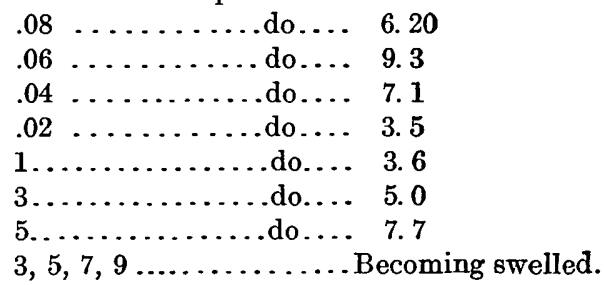

Color after burning. . . . . . . . . . . . Very poor red color.

Hardness........................ Soft at cone .010, steel hard at higher temperature.

Best burning temperature..........

Remarks. . . . . . . . . . . . . erties, drying behavior, color, etc. Could not be used in the manufacture of clay products.

No. 393. CLAY FROM PIT OF TEXAS FULLER'S EARTH PLANT, NEAR BURTON, WASHINGTON COUNTY.

Seven miles north of Burton, on the David Heirs League, in Washington County, are located the plant and pit of the Texas Fuller's Earth Co. (No. 393, Pl. VI). At this place fuller's earth was manufactured and a small quantity was shipped in 1909.

The deposit is a soft brown fuller's earth representing a deposit laid down in a lagoon adjacent to the shore in late Jackson time. It covers some 250 acres of ground, its occurrence over this territory 
having been proved by borings and systematic prospecting. At the pit the following section is exposed:

\section{Section at pit of Texas Fuller's Earth Co., near Burton.}

1. Sand with interstratified clay seams 2 inches thick; overburden.. 10

2. Soft brown fuller's earth.......................... 4

3. Lignitic shale............................... $\frac{1}{2}$

4. Soft brown fuller's earth......................... 5

Thus far stratum No. 2 has been the only one worked for fuller's earth.

A drill hole about 300 feet north of this pit is reported to have passed through the following beds:

Section of drill hole north of Burton.

\begin{tabular}{|c|c|c|}
\hline & $\begin{array}{l}\text { Thick- } \\
\text { ness. }\end{array}$ & Depth. \\
\hline 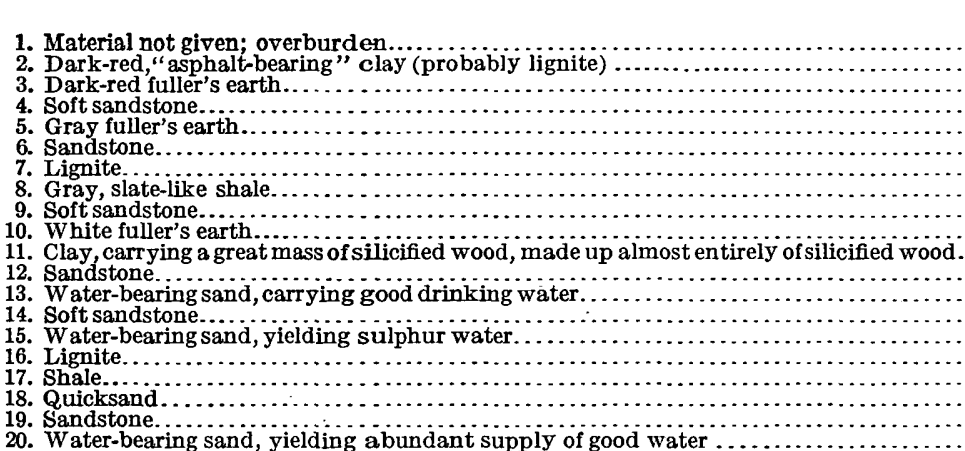 & \begin{tabular}{|rr}
$F t$. & in. \\
6 & \\
1 & \\
7 & 10 \\
5 & 6 \\
4 & \\
& 6 \\
4 & \\
7 & 2 \\
3 & \\
4 & 6 \\
4 & 6 \\
1 & \\
15 & \\
4 & \\
6 & \\
2 & \\
4 & \\
2 & \\
2 &
\end{tabular} & \begin{tabular}{|cc}
$F t$. & in. \\
6 & \\
7 & \\
14 & 10 \\
15 \\
20 & \\
24 & \\
24 & 10 \\
28 & 10 \\
36 & \\
39 \\
39 & \\
44 \\
45 \\
60 \\
64 \\
70 \\
72 \\
76 \\
78 \\
80
\end{tabular} \\
\hline
\end{tabular}

The lignite numbered 16 in the section above was found to be 38 inches thick at a depth of 36 feet in drill hole No. 17, about 300 feet southwest of the pit. Drill holes Nos. 10 and 11,300 and 350 feet, respectively, west of the pit, struck this bed of lignite at 44 feet below the surface, hole No. 10 showing 5 feet of lignite and hole No. 11 4 feet.

Drill hole No. 8 , about 300 feet northeast of the pit, showed 5 feet of overburden above $7 \frac{1}{3}$ feet of the fuller's earth. Drill hole No. 3, about 50 feet $\mathrm{N} .10^{\circ} \mathrm{E}$. from hole No. 8, showed 6 feet of overburden on top of 6 feet of fuller's earth. Drill hole No. 4, about 75 feet east of hole No. 3, showed 7 feet of overburden on top of 5 feet of fuller's earth. Drill hole No. 5, about 100 feet east of No. 4, showed 7 feet of overburden on top of $4 \frac{1}{2}$ feet of fuller's earth. Drill hole No. 10, 375 feet northwest of hole No. 17, showed 4 feet of overburden on top of 7 feet of fuller's earth. Drill hole No. 11, about 100 feet east of No. 10, showed 5 feet of overburden above $7 \frac{1}{2}$ feet of fuller's earth. Drill hole No. 12, about 200 feet east of No. 11, showed $5 \frac{1}{2}$ feet of overburden on top of $7 \frac{1}{2}$ feet of fuller's earth. 
The results of these drillings, as well as others, seem to show that there is available here, over 200 acres of ground or more, a bed of fuller's earth averaging 5 feet in thickness, covered with an overburden of soil, gravel, and clay that will average 6 feet in thickness.

The topography in this vicinity is generally sublevel, the creeks and drainways flowing in small canyons and hollows. The area is veneered with a thin coat of Pleistocene gravel, consisting of quartz, flint, jasper, etc. In places this gravel is covered with a brown plastic loam of the Lufkin soil series and the region is generally covered with a growth of post oak.

Burton, 7 miles distant on the Houston \& Texas Central Railroad, is the nearest shipping point. The plant is not connected with the railroad by a spur, and it has been necessary to haul the prepared earth to Burton by wagon. For this reason the operations proved unprofitable.

The existence of lignite in this locality that can be mined for fuel has already been mentioned. The nearest lignite mines are those at Ledbetter, some 15 miles distant. During the period of operation, however, wood was used for fuel, being cut from this and adjacent land and delivered at the plant at prices, it is stated, averaging $\$ 1$ a cord. This price does not cover the stumpage value of the wood. Water can be drawn from wells. To furnish a supply for generating steam at this plant, however, a storage reservoir was built and surface water was impounded. Drainage of the pits was secured by a natural system, without resort to pumps, the bottoms of the pits lying generally higher than the main creeks.

This deposit was worked only for a period. of a few months in 1909. A $\$ 47,000$ plant was erected here. It was soon found that operations were being conducted at a loss and work was suspended. The mill is equipped with drying and pulverizing machinery, one burr mill being used. The grinding machinery is capable of reducing the clay to a size varying from 40 to 200 mesh. Labor was supplied by negroes at a cost of $\$ 1$ to $\$ 1.25$ a day. There were no especial quarrying facilities, the clay being dug from the pit by pick and shovel and hauled to the mill by wagons.

The failure here was doubtless due to the unsatisfactory location of the plant. The cost of working clay under 6 feet of overburden was excessive, and to this was added the cost of hauling the prepared earth 7 miles to a shipping point and hauling back supplies. The poor location is especially open to criticism because deposits of fuller's earth of as good quality can be found in this State practically adjacent to railroads, and without an excess of overburden. Tests to determine the value of this clay when used as fuller's earth have not yet been completed. The results given below show that this material is not adapted for the manufacture of burned products. 
Burning behavior and physical properties of the clay from the pit of the Texas Fuller's Earth Co., 7 miles north of Burton (No. 393).

Description of raw clay.............. Soft light-brown fine-grained shale; grinds easily.

Molding behavior...................Fuller's earth, very plastic; works poorly on machine.

Drying behavior................... Impossible to dry; cracks and warps; all pieces made by hand and on machine cracked.

Porosity at cone $.010 \ldots . . . .$. per cent. . 32.00

$.08 \ldots . . . . . . .$. . do.... 17.90

$.06 \ldots . . . . . .$. . do.... 17. 20

$.04 \ldots . . . . . .$. do... 8.20

$.02 \ldots . . . . .$. . do... 8.40

$1 \ldots \ldots . . . .$. do... 5.9

$3 \ldots . . . . . . .$. . do... 3.80

$5 \ldots \ldots \ldots$.......... 5.5

$7,9 \ldots \ldots$....... do .... Vesicular.

Color after burning................. Very unpleasant red color.

Hardness........................ Increasing hardness from cone .010 to cone 3 ; vesicular at cone 5 .

Best burning temperature............. $1,190^{\circ} \mathrm{C}$.

Remarks........................... products. Has unsatisfactory working, drying, and burning behavior, and a poor color.

No. 432. FULLER'S EARTH ON MELCHER PROPERTY NEAR WEST POINT, FAYETTE COUNTY.

Five miles south of West Point, on lot 84, W. F. Hamilton League, in Fayette County, on land belonging to J. C. Melcher, of O'Quinn, is another considerable deposit of fuller's earth. (See Pl. VI, No. 432, and Pl. VII.) All of the area marked on Plate VII as being underlain by lignite also contains this bed of brown fuller's earth, ranging in thickness from 6 to 16 feet and lying under 2 to 10 feet of overburden. A large body of this earth is available.

On lot 84 of the W. F. Hamilton League, along the banks of a small hollow, this fuller's earth is well exposed, showing a section 16 feet in thickness, very uniform in physical and chemical composition, overlain by 2 feet of Pleistocene gravel. The gravel could be utilized for ballast, and a plant at this point could be operated very economically as there is little overburden, the clay is present in a very thick bed, natural drainage facilities are available, wood and lignite are abundant, and the deposit is but half a mile from the San Antonio \& Aransas Pass Railway.

This earth is of a light-brown color, a very fine, almost compact texture, and a hardness between 2 and 3 on the Mohs scale. A slight film of limonite appears on the joint and lamination planes.

The results of tests to determine the value of this material as fuller's earth are not yet available for publication. Mr. Melcher 
makes the following statement in regard to certain tests made on samples collected by him:

This *** fuller's earth *** was tested in May, 1908, by the State of Texas, at College station, Texas, in connection with a number of earths from different deposits in Texas, and in comparison with the standard imported English earths of 100 points bleaching powers for cotton oil. The Melcher No. 1 M. B. went as high as 224 points, and the Melcher No. 1 M. went as high as 207 points, with no bad tastes or bad odors, nor changes in colors after standing two weeks exposed to open atmosphere.

Tests made by this Survey show that this clay is not adapted for the manufacture of burned products. The results of these tests follow:

Burning behavior and physical properties of the clay on the Melcher property south of West Point (No. 432).

Description of raw clay.............. Brown, medium, fine-grained shale; grinds easily.

Molding behavior

Very plastic and sticky; gives smooth column on machine; laminated structure.

Drying behavior Warps and cracks on drying in air.

Drying shrinkage:

Per cent of wet length . . .......... 11. 58

Per cent of wet volume.......... 36.65

Burning shrinkage, per cent of dry length. 7.7

Total linear shrinkage, per cent of wet

length

Porosity at cone $.010 \ldots \ldots \ldots$. . per cent. . 32.10

$.08 \quad \ldots \ldots . . .$. . do.... 27.00

.06 ................... 18.60

$.04 \ldots . . . . .$. . do.... 6.30

$1 \ldots \ldots . . . . .$. do.... 4.70

$3 \ldots \ldots \ldots$............ 2.10

$5 \ldots \ldots \ldots . . . .$. do... 4.60

$3,5,7,9 \ldots \ldots \ldots \ldots . . . .$. Becoming vesicular.

Color after burning................ Unsatisfactory buff color.

Hardness............................ vitreous at cone 5 .

Best burning temperature.............

Remarks ...................... Vesicular structure developed; high drying shrinkage; gives trouble by cracking during burning.

NO. 381. CLAY ON MURRAY FARM NEAR LYONS, BURLESON COUNTY.

On the J. C. Murray farm, 3 miles north of Lyons, Burleson County, occurs a hard blue shale that may be tentatively classed as fuller's earth. The location is indicated on Plate VI by No. 381. This shale occurs in the upper portion of the Cockfield formation, apparently, lying just beneath the Jackson formation. This bed immediately overlies the clay of the Opperman property (No. 380), which dips beneath it. 
On a branch of Davidson Creek a shaft put down by Mr. Murray exposes the following beds, as noted by the writer:

Section in Murray shaft, near Lyons.

1. Soil, with gravel interspersed

2. Blue shale, same bed as clay on opperman property $(\mathrm{No} .380)$

3. Gray sandstone...

4. Blue shale, same as $\mathrm{No} .2$

5. Gray sandstone, same as No. 3 (this sandstone does not appear in the shaft 135 feet south of this one, having pinched out)

6. Blue shale or fuller's earth

7. Sandstone, not penetrated.

\begin{tabular}{|c|c|}
\hline $\begin{array}{l}\text { Thick- } \\
\text { ness. }\end{array}$ & Depth. \\
\hline $\begin{array}{cc}\text { Ft. } & \text { in. } \\
2 \\
3 \\
2 \\
2 \\
8 & 7\end{array}$ & $\begin{array}{cc}\text { Ft. in. } \\
2 & \\
5 & \\
7 & \\
7 & 8\end{array}$ \\
\hline $\begin{array}{l}1 \\
5\end{array}$ & $\begin{array}{rr}8 & 8 \\
13 & 8\end{array}$ \\
\hline
\end{tabular}

Bed No. 6 consists of a compact blue shale, of uniform chemicai and physical composition, with hardness between 2 and 3 . The joint planes contain a slight film of limonite but are not very numerous.

A number of additional shafts have been put down on this farm to prove the value of this clay. The sections exposed in these shafts are as follows:

Sections in shafts on Murray farm, near Lyons.

No. 1, on the banks of a branch of Davidson Creek.

Feet.

Gray sandstone

2

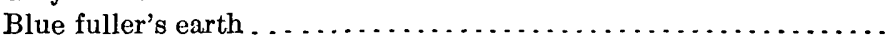

Sand, loose.

4

$2 \frac{1}{2}$

No. 2, about 500 feet a little east of north from No. 1.

Black soil

Feet.

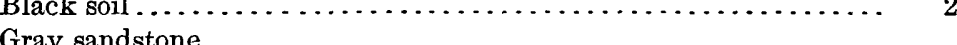

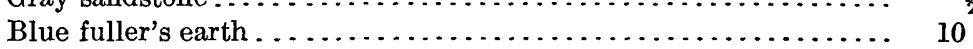

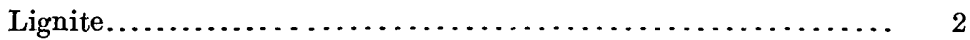

No. 3, about 100 feet a little west of north from No. 2.

$14 \frac{1}{2}$

Feet.

Overburden, black soil......................... 2

Red fuller's earth, probably weathered phase of bed below ..... 3

Blue fuller's earth . . . . . . . . . . . . . . .

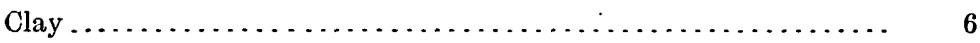

Lignite.

No. 4, about 200 east of No. 3.

Feet.

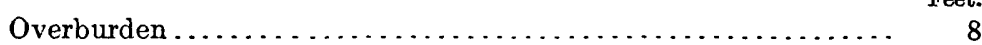

Gray fuller's earth................................. 4

Blue fuller's earth.................................. 8 
No. 5 , about 600 feet a iittle east of south from No. 1 .

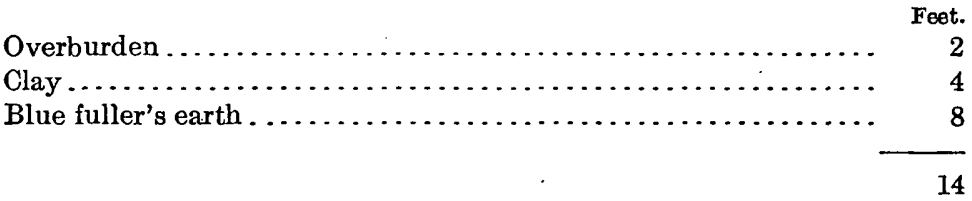

No. 6, about 300 feet west of No. 5 .

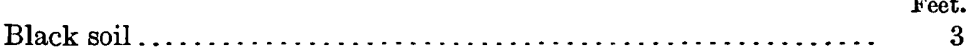

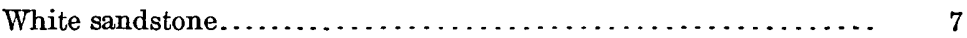

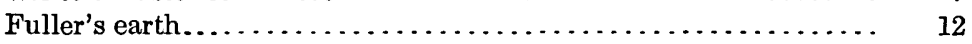

The area covered by these prospect shafts is 40 acres. The fuller's earth that is found in them is probably available, however, over 70 or 80 acres of ground.

The main line of the Gulf, Colorado \& Santa Fe Railway crosses this farm, so that this deposit is very favorably situated with regard to transportation facilities. Any clay pits opened here could be readily drained without pumping. The conditions as regards labor and fuel are similar to those for other clays in the general vicinity of Somerville.

It is thought that this clay may be useful as a fuller's earth, but thus far tests to prove its value for this purpose have not been completed. Burning tests show emphatically that this clay is not adapted for the manufacture of burned products. The results of these tests appear below.

Burning behavior and physical properties of clay on J. C. Murray farm, 3 miles north of Lyons, Burleson County (No. 381).

Description of raw clay.............. Blue shale, medium, fine grained; grinds easily.

Molding behavior

Fuller's earth(?); laminates excessively.

Drying behavior.

Warps and cracks; not possible to make draw trials.

Drying shrinkage, per cent of wet length. .10.6.

Remarks.......................... clay is of absolutely no value as a material for manufacturing clay products. It was not tested for fuller's earth.

NO. 383. CLAY ON PAUL TAYLOR FARM NORTHWEST OF SOMERVILLE, BURLESON COUNTY.

On the Paul Taylor farm, $1 \frac{1}{2}$ miles northwest of Somerville, Burleson County, occurs an extensive deposit of compact brown leaf-bearing shale that may be tentatively classed as fuller's earth. The location is indicated by No. 383 on the map (Pl. VI).

This deposit occurs in the Jackson formation and lies directly on top of the gray sandstones which have been previously described as 
overlying the clay at the Somerville fuller's earth plant. This clay is very well exposed on a branch of Yegua Creek, where the following section may be seen:

Section on branch of Yegua Creek near Somerville.

1. Brown clay soil, with specks and small particles of gravel (overburden)............................... 1.6

2. Laminated brown shale, with seams of sand 1 inch thick..... 5.2

3. Compact, massive brown shale, with flakes of gypsum, etc., also carrying leaf impressions...................... 13.2

No. 3 is the commercially valuable clay. The clay is fine grained, even textured, and of uniform chemical and physical composition over a large area. It breaks with a subconchoidal fracture; its hardness is between 2 and 3 on the Mohs scale. This bed dips half a degree to the east-southeast.

M. M. Graves, of Somerville, has prospected this deposit by means of shafts and states that he has found this clay covering some 57 acres of ground, beneath an overburden that will average 5 or 6 feet in thickness. The precise records of these shafts are unfortunately not available, and the shafts themselves were filled up soon after they were dug.

This deposit is situated 500 yards west of the main line of the Gulf, Colorado \& Santa Fe Railway, and can be easily reached with a spur. Facilities for the natural drainage of any clay pits that might be opened here are good. The conditions as regards labor, fuel, and water are similar to those for other clays in the general vicinity of Somerville.

Tests to determine the value of this clay for fuller's earth indicate, according to Mr. Graves, high bleaching and decolorizing power. The survey tests on samples collected by the writer are not yet complete.

The burning tests seem to indicate that this clay is not very well adapted for the manufacture of burned products. It cracks badly in drying and fuses at a comparatively low temperature. The difficulties might in part be corrected by the addition of sand, but it is questionable whether this would prove profitable in view of the great abundance of available brick clays in this State. The results of these burning tests appear below:

Burning behavior and physical properties of clay on Paul Taylor place, $1 \frac{1}{2}$ miles north of Somerville (No. 383).

Description of raw clay.............. Fine-grained, medium-hard shale; tempered in wet pan(?).

Molding behavior................... . Very plastic; works well on machine.

Drying behavior................... Warps and cracks badly.

Drying shrinkage:

Per cent of wet length........... 11.4

Per cent of wet volume. . ......... 34.00 
Burning shrinkage, per cent of wet length..........................

Total linear shrinkage, per cent of wet length 6.3

Porosity at cone $.010 \ldots \ldots \ldots$....... per cent. . 28. 34

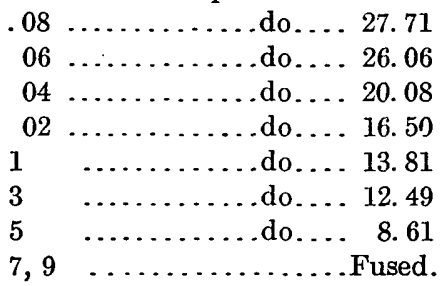

Color after burning................. Buff; darkens at higher temperature.

Hardness. . . . . . . . . . . . . . . . . . . Steel hard from cone .08 to cone .5 .

Best burning temperature.............

Remarks.......................... not well suited for clay products, owing to difficulty in drying and short vitrification range.

No. 394. CLAY ON RED GULIY CREEK NEAR BURTON, WASHINGTON COUNTY.

On Red Gully Creek, on the David Heirs League, $7 \frac{1}{2}$ miles north of Burton, Washington County, occurs a deposit of hard brown leafbearing shale which belongs to William Bauer, of Burton. The location is indicated by No. 394 on Plate VI.

This deposit is similar in geologic relations to clay No. 383 .

The clay is nicely exposed in the canyon walls of Red Gully Creek. Half a mile north of the Texas Fuller's Earth Co.'s plant the following section is exposed in the bank of this creek:

Section in bank of Red Gully Creek 4 miles north of Burton.

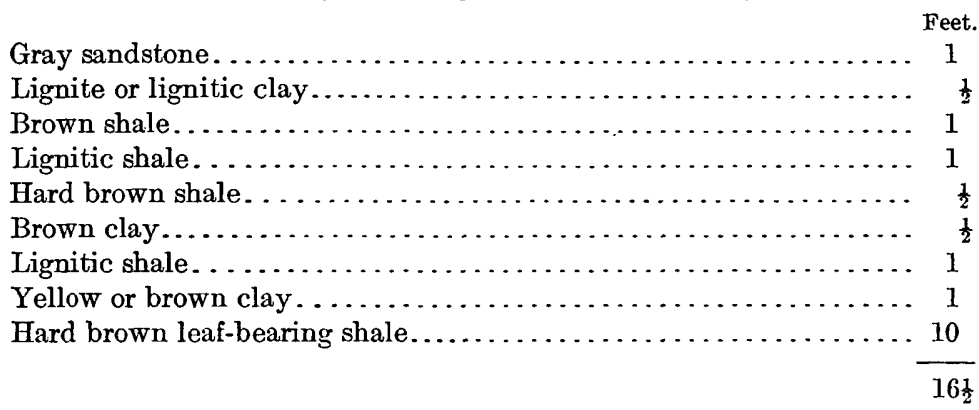

The leaf-bearing shale is compact, fine grained, of uniform chemical and physical composition, but excessively hard, the hardness being between 3 and 4 on the Mohs scale. The beds dip slightly to the south.

Frank Graves, of Burton, has prospected this deposit and gives the following details concerning its extent and distribution as revealed by his drill holes: 
Drill hole No. 1, about one-fourth mile north of the Texas Fuller's Earth Co.'s plant and about half a mile south of the exposure in Red Gully just described, showed 3 feet of stripping on top of 5 feet of the brown fuller's earth. Drill hole No. 2, about 200 feet N. $45^{\circ}$ E. from hole No. 1, showed 22 inches of overburden on top of 5 feet of brown fuller's earth. Hole No. 3, about 200 feet $\mathrm{N}$. $45^{\circ}$ E. from No. 2, showed 20 inches of overburden on top of 5 feet 3 inches of brown fuller's earth. Hole No. 4, about 200 feet N. $45^{\circ}$ E. from No. 3, showed 20 inches of overburden overlying $5 \frac{1}{2}$ feet of brown fuller's earth. Hole No. 5, about 300 feet N. $45^{\circ}$ E. of No. 4, showed 18 inches of overburden on top of 6 feet of fuller's earth. Hole No.6, 100 yards distant from No. 5, contains no fuller's earth, being apparently beyond the northern limit of its outcrop. Only sandstone appears in this drill hole. Hole No. 7 , about 200 yards west of hole No. 1, showed 7 feet 10 inches of fuller's earth, overlain by 7 feet of overburden, of which the uppermost foot is sandstone. Practically the same conditions were met in holes Nos. 8 and 9 , distant 300 and 600 feet, respectively, from hole No. 7 in a direction N. $10^{\circ} \mathrm{W}$. No. 10 , a shaft located about 300 feet N. $10^{\circ} \mathrm{W}$. from No. 9 , showed 10 feet of hard brown fuller's earth (probably the same as the stratum described in the section on Red Gully) overlying 5 feet of fine white fuller's earth. Hole No. 11, about 600 feet N. $10^{\circ} \mathrm{W}$. from the shaft (No. 10), showed 4 feet of overburden on top of 3 feet of reddishbrown fuller's earth, which in turn lies on top of 5 feet of white fuller's earth. Hole No. 12, on the east side of Red Gully, about 1,200 feet north of hole No. 4, showed a large quantity of fuller's earth, which was not penetrated.

This entire tract covers 49 acres. It is probable that the drill holes above described have penetrated one or more beds of fuller's earth, not all of which are stratigraphically continuous with the leaf-bearing bed in the section on Red Gully described on page 347. In any event, there is present here a considerable body of clay that will vary in thickness from 5 to 10 feet, covered with 2 to 5 feet of overburden. It is probable that the area described contains a number of clays that differ from one another, at least in chemical composition.

This deposit is situated $7 \frac{1}{2}$ miles north of Burton, the nearest railroad point. For the present therefore this clay is not commercially available and could come on the market only in the event that a railroad should be built through this territory.

Tests made by Frank Graves show that this clay possesses good bleaching power.

The country here is cut into canyon-like hollows by the creeks and is veneered with a thin sheet of gravel and covered with post-oak timber. Facilities for the natural drainage of clay pits exist here. The conditions as regards possible supplies of fuel, labor, and water 
are similar to those indicated for the deposit of the Texas Fuller's Earth Co.

It appears from the results of the burning tests that this clay is well adapted for the manufacture of building brick, etc. The results of these tests follow:

Burning behavior and physical properties of clay on Rèd Gully Creek, $7 \frac{1}{2}$ miles north of Burton (No. 394).

Description of raw clay............... Brown, medium fine grained shale; grinds easily.

Molding behavior

.Fuller's earth(?); good working plasticity; rather sandy; works well on machine.

Drying behavior. Good.

Drying shrinkage:

Per cent of wet length............... 7.52

Per cent of wet volume............. 20.40

Burning shrinkage, per cent of wet volume. 7.6

Total linear shrinkage, per cent of wet

length

15. 12

Porosity at cone $.010 \ldots \ldots \ldots . .$. per cent. . 42.00

.08 ................... 37.20

.06 .................... 33.60

.04 ................ do.... 28. 40

.02 .................... 32.00

1 ................ do... 25. 30

3..............do... 29. 10

$5 \ldots \ldots \ldots \ldots$......... 19.80

$7 \ldots \ldots \ldots$.......... 18. 70

$9 \ldots \ldots \ldots \ldots \ldots \ldots$ Melting point not determined.

Color after burning................. Fair buff.

Hardness.......................... Steel hard at cone 5; stands well at cone 9.

Best burning temperature.............

Remarks....................... This clay is favorable for the manufacture of building bricks, etc.

No. 404. CLAY ON BURKHART LAND NEAR LEDBETTER, IN WASHINGTON COUNTY.

On the Burkhart land, on a branch of Turkey Creek, about 2 miles east of Ledbetter, in Washington County, occurs another deposit of brown shale or fuller's earth that is similar in general character and geologic relations to the clay of the Somerville Fuller's Earth Co. (p. 337). The location is indicated by No. 404 on the map (Pl. VI).

This deposit is apparently stratigraphically continuous with the Somerville fuller's earth (No. 382) and, like that clay, is doubtless of lacustrine or palustrine origin, having been deposited in a lagoon or swamp adjacent to the shore in Jackson time. 
On the creek the following exposure may be seen:

Section on branch of. Turkey Creek, 2 miles east of Ledbetter.

Hard gray sandstone, apparently the stratigraphic equivalent of the sandstone that overlies the clay at the Somerville fuller's Feet. earth plant; this sandstone is used locally for building...... 4-5

Hill slope, covered with gravel and soil; beds not visible..... 35

Yellow shale, exposed ........................... 2

Hard brown shale................................. 2

Soft brown shale............................... $5+$

$47-48$

The soft brown shale is the apparently commercially valuable clay at this point. This clay is a compact, even-grained light-brown shale or fuller's earth of uniform physical and mineralogical composition over a considerable area. The beds dip slightly to the south.

Regarding the extent of this deposit little is definitely known. However, there can be little doubt that this clay covers an extensive area in this section, for it was found in the shaft at the lignite mines 2 miles west of the exposure described above.

The overburden varies in places from 2 to 5 feet in thickness; at least it will be possible to locate an area of clay in this vicinity in which the overburden will not exceed 5 feet. This covering consists chiefly of Pleistocene gravel, which extensively veneers the surface in this vicinity, and clay. There is no great amount of rock. A considerable demand has been developed in this vicinity for the gravels for railroad ballast, and a great number of pits are operated and ship gravel for this purpose. Some of the land in this region commands as much as $\$ 30$ an acre merely because it contains gravel. The overburden therefore is not a hindrance to the working of these clay deposits, because it can be removed as a by-product and sold at a profit.

This gravel flat is covered with a heavy growth of post-oak timber, which is available as fuel. In addition, a considerable body of lignite occurs 50 to 60 feet beneath this clay. This lignite has been worked in times past at Ledbetter, and it is expected that operations on it will be resumed in the near future. This deposit is but a mile distant from the Austin branch of the Houston \& Texas Central Railroad and could be readily reached with a spur. Drainage of clay pits could probably be provided by a natural system, though it may be necessary to resort to pumps in the course of time. For labor, negroes and Mexicans can be hired at prices ranging from $\$ 1$ to $\$ 1.50$ a day. Water can be had in wells and from impounding reservoirs.

The tests to determine the value of this clay as a fuller's earth have not been completed. Burning tests seem to show that it is not adapted to the manufacture of burned products. It cracks badly in 
drying, fuses easily and rapidly, and burns to an unsatisiactory color. The results of these tests appear below:

Burning behavior and physical properties of clay on Burkhart lands near Ledbetter (No. 404).

Description of raw clay................Hard brown sbale; grinds easily.

Molding behavior.................... Very plastic and sticky; works well on machine.

Drying behavior.................... Cracks; made over by hand. No shrinkage measurements.

Pornsity at cone $.010 \ldots . . \ldots .$. per cent. . 32.60

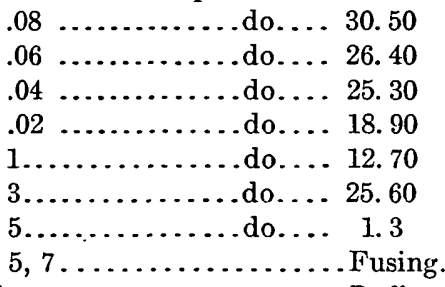

Color after burning................. Buff at lower temperature; a poor red at higher.

Hardness......................... Vesicular at cone 3 ; fused at cone 5 .

Best burning temperature............

Remarks..................... Unsatisfactory in drying, vitrifying range, and color. 


\section{SURVEY PUBLICATIONS ON CLAYS, FULIER'S EARTH, ETC.}

In addition to the papers named below, some of the publications listed under the heading "Cement and concrete materials" contain references to clays. Certain of the geologic folios also contain references to clays, fuller's earth, etc.

These publications, except those to which a price is affixed, can be obtained free by applying to the Director, United States Geological Survey, Washington, D. C. The priced publications may be purchased from the Superintendent of Documents, Government Printing Office, Washington, D. C.

Alden, W. C. Fuller's earth and brick clays near Clinton, Mass. In Bulletin 430, pp. 402-404. 1910.

Ashley, G. H. Notes on clays and shales in central Pennsylvania. In Bulletin 285, pp. 442-444. 1906.

Ashuey, F. E. The colloid matter of clay and its measurement. Bulletin 388 . $65 \mathrm{pp} .1909$.

Bastin, E. S. Clays of the Penobscot Bay region, Maine. In Bulletin 285, pp. 428-431. 1906.

Branner, J. C. Bibliography of clayys and the ceramic arts. Bulletin 143. 114 pp. 1896. 15c.

- The clays of Arkansas. Bulletin 351. 247 pp. 1908.

Butts, Charles. Clays of the Birmingham district, Alabama. In Bulletin 315, pp. 291-295. 1907. 50c.

Crider, A. F. Clays of western Kentucky and Tennessee. In Bulletin 285, pp. 417-427. 1906.

Darton, N. H. Geology and water resources of the northern portion of the Black Hills and adjoining regions in South Dakota and Wyoming. Professional Paper 65. 106 pp. 1909.

Darton, N. H., and Siebenthal, C. E. Geology and mineral resources of the Laramie Basin, Wyoming; a preliminary report. Bulletin 364.81 pp. 1909.

ECKEL, C. E. Stoneware and brick clays of western Tennessee and northwestern Mississippi. In Bulletin 213, pp. 382-391. 1903. 25c.

- Clays of Garland County, Ark. In Bulletin 285, pp. 407-411. 1906.

Fenneman, N. M. Clay resources of the St. Louis district, Missouri. In Bulletin 315, pp. 315-321. 1907. 50c.

Frsher, C. A. The bentonite deposits of Wyoming. In Bulletin 260, pp. 559-563. 1905. $40 \mathrm{c}$.

Clays in the Kootenai formation near Belt, Mont. In Bulletin 340, pp. 417-423. 1908.

Fuller, M. L. Clays of Cape Cod, Massachusetts. In Bulletin 285, pp. 432-441. 1906.

Landes, Henry. The clay deposits of Washington. In Bulletin 260, pp. 550-558. 1905. 40c. 
Lines, E. F. Clayg and shales of the Clarion quadrangle, Clarion County, Pa. In Bulletin 315, pp. 335-343. 1907. 50c.

Matson, G. C. Notes on the clays of Florida. In Bulletin 380, pp. 346-356. 1909.

Middeton, Jefferson. Clay-working industries. In Mineral Resources U. S. for 1909, pt. 2, pp. 453-517. 1911. ${ }^{1}$

Phalen, W. C. Clay resources of northeastern Kentucky. In Bulletin 285, pp. 412-416. 1906.

Economic geology of the Kenova quadrangle, Kentucky, Ohio, and West Virginia. In Bulletin 349, pp. 112-122. 1908.

Phalen, W. C., and Martin, Lawrence. Mineral resources of Johnstown, Pa., and vicinity. Bulletin $447.140 \mathrm{pp} .1911$.

Clays and shales of southwestern Cambria County, Pa. In Bulletin

315, pp. 344-354. 1907. 50c.

Porter, J. T. Properties and tests of fuller's earth. In Bulletin 315, pp. 268-290. 1907. 50c.

RiEs, H. Technology of the clay industry. In Sixteenth Ann. Rept., pt. 4, pp. 523-575. 1895. \$1.20.

- The pottery industry of the United States. In Seventeenth Ann. Rept., pt. 3, pp. 842-880. 1896.

- The clays of the United States east of the Mississippi River. Professional Paper 11. 298 pp. 1903. 40c.

Schrader, F. C., and Haworth, E. Clay industries of the Independence quadrangle, Kansas. In Bulletin 260, pp. 546-549. 1905. 40c.

Shaler, M. K., and Gardner, J. H. Clay deposits of the western part of the Durango-Gallup coal field of Colorado and New Mexico. In Bulletin 315, pp. 296302. 1907. 50c.

Shaler, N. S., Woodworth, J. B., and Marbut, C. F. The glacial brick clays of Rhode Island and southeastern Massachusetts. In Seventeenth Ann. Rept., pt. 1, pp. 957-1004. 1896.

Siebenthad, C. E. Bentonite of the Laramie Basin, Wyoming. In Bulletin 285, pp. 445-447. 1906.

Stose, G. W. White clays of South Mountain, Pennsylvaina. In Bulletin 315, pp. 322-334. 1907. 50c.

VAN HoRn, F. B. Fuller's earth. In Mineral Resources U. S. for 1907, pp. 731-734, pt. 2. 1908. $\$ 1.00$.

VAUGHan, T. W. Fuller's earth of southwestern Georgia and Florida. In Mineral Resources U. S. for 1901, pp. 922-934. 1902. 50c.

- Fuller's earth deposits of Florida and Georgia. In Bulletin 213, pp. 392-399. 1903. 25c.

Veatch, O. Kaolins and fire clays of central Georgia. In Bulletin 315, pp. 303314. 1907. 50c.

Woolsey, L. H. Clays of the Ohio Valley in Pennsylvania. In Bulletin 225, pp. 463-480. 1904. 35c.

1 Previous volumes of the Mineral Resources of United States contain chapters devoted to clay and the clay-working industries of the United States.

$94174^{\circ}-$ Bull. $470-11-23$ 


\section{GYPSUM AND PLASTERS.}

GYPSUM DEPOSITS IN EAGLE COUNTY, COLORADO.

By Ernest F. Burchard.

\section{INTRODUCTION.}

In the summer of 1910 the writer, while investigating a number of deposits of gypsum of possible commercial value in the Western States, made a very hasty reconnaissance of the gypsum deposits of Eagle County, Colo. Of the many areas visited that of Eagle County seems the most worthy of special mention on account of the large quantity of gypsum rock that is available along the main line of the Denver \& Rio Grande Railroad. (See fig. 44.) The local descriptions given below are a transcript of field notes and are supplemented by a few analyses made in the laboratories of the United States Geological Survey; they are intended merely to call attention to the deposits rather than to give a complete description of the area. As the Survey has no facilities for making practical tests of the quality of the gypsum, this feature necessarily is the least cortain of all the facts under consideration. Judged by appearances these gypsum deposits are as promising as many that are worked for making plasters in other parts of the West, and most of them are far more easily accessible.

Before the development of any deposit of gypsum is undertaken very careful investigations should be made of the quality of the material and of the quantity available. Chemical analyses of a few selected samples are not sufficiently reliable, nor are chemical analyses of large quantities of representative material to be relied upon implicitly. Large quantities of the material should be calcined and made into plaster, and the characteristics of the plaster should be determined before any money is spent in clearing ground for a mill.

\section{GEOLOGIC RELATIONS.}

No geologic maps or detailed studies of the stratigraphy within Eagle County have been made by the United States Geological Survey. Hayden, Peale, and others studied this region in 1873 and 1874 and published the results of their work in volumes 7 and 8 of 
the reports and in the atlas of topographic and geologic maps issued by the Geological and Geographical Surveys of the Territories. Mr. E. M. Kindle, of the United States Geological Survey, has recently made paleontologic studies in the canyon of Grand River 4 or 5 miles below the Eagle County line and has kindly examined some fossils collected by the writer from Cottonwood Creek, thereby determining with certainty the age of some limestone beds that lie not far below the gypsum-bearing formation.

Eagle River, which enters the county near its southeast corner and flows northwest and west to its confluence with Grand River at

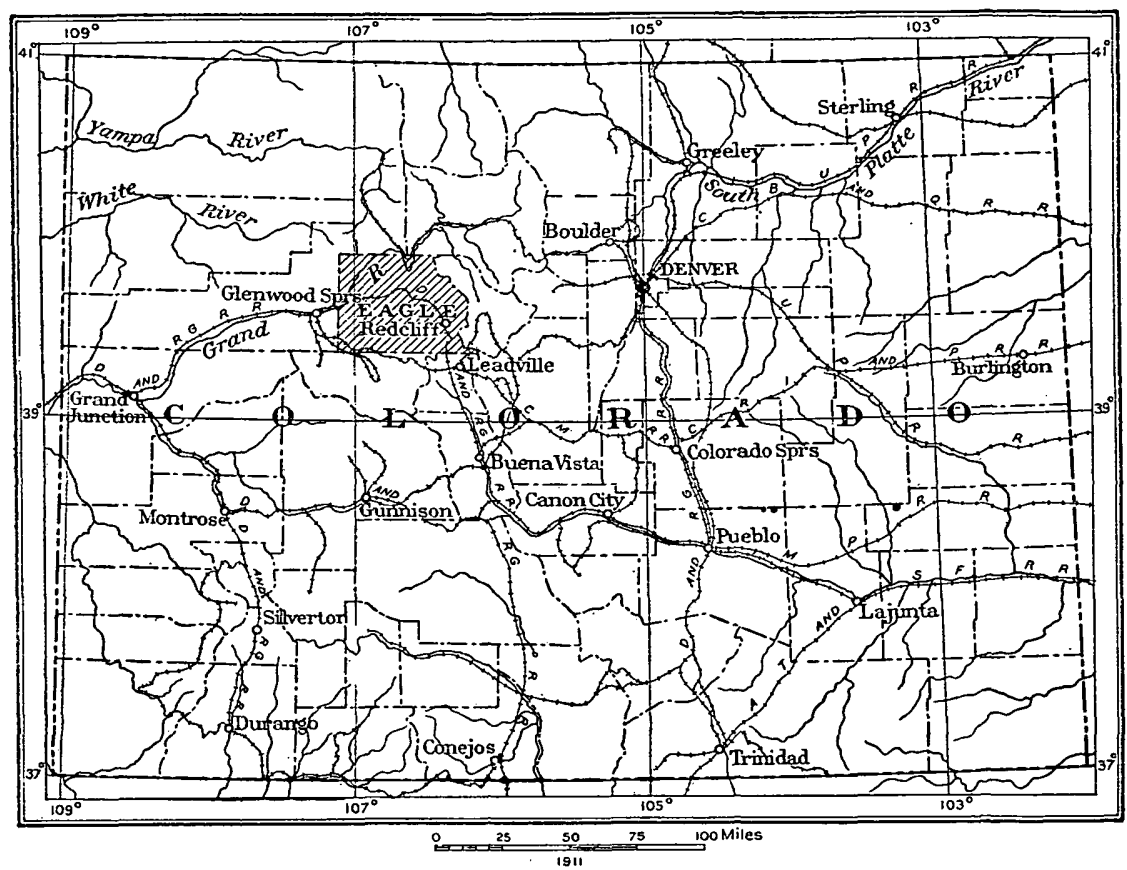

FIGURE 44.-Index map of Colorado, showing location of Eagle County.

Dotsero, in the middle of the county, is the major drainage feature of the county. Grand River, which flows across the northwest corner of the county, is geographically the next feature of importance. The surface is in general rough, with a maximum relief of over 6,000 feet between the level of Eagle River, which is about 7,000 feet above sea level in the western part of the county, and the summit of Mount Powell, which has an altitude of more than 13,000 feet. There are three shallow canyons on Eagle River; the upper is above Redcliff, the second is near Wolcott, and the lower is below the mouth of Gypsum Creek. Between these canyons are comparatively broad valleys occupied by flood-plain deposits, and the valleys of Gypsum Creek, Brush Creek. South Eagle River, and Beaver Creek are of similar 
nature and are wide enough in their lower reaches for agricultural purposes. Eagle River throughout most of its course in the county and Grand River below the mouth of Eagle River flow along the axis of a syncline composed of sedimentary rocks of Ordovician, Silurian, Devonian, Carboniferous, Triassic, Jurassic, Cretaceous, and Tertiary age, the oldest of these sediments resting on gneissoid and granitic crystalline rocks. This synclinal trough is slightly basinshaped, with the deepest depression in the vicinity of Wolcott, where the Cretaceous and Tertiary beds cap the surfaces adjacent to the river. In a few places there are remnants of basalt flows on the higher levels overlying the Tertiary rocks.

The approximate thickness of the systems of sedimentary rocks in northwestern Colorado is as shown below, according to Peale. ${ }^{1}$ The Cretaceous and Tertiary rocks do not reach such great thicknesses as far east as Eagle County.

Sedimentary formations in Eagle County, Colo.

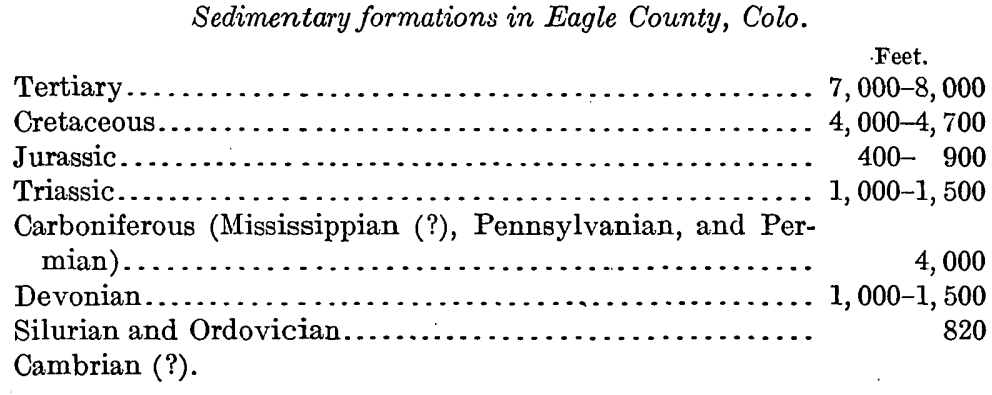

The gypsum beds occur in the upper part of the Carboniferous system, probably in the Permian series, and these are the only rocks that need to be considered here. The Hayden Survey mapped the Carboniferous rocks as Lower, Middle, and Upper. The Lower division probably corresponds roughly to the Devonian and Mississippian rocks, and the Middle and Upper divisions to the Pennsylvanian and Permian series. The thickness of the upper division of the Carboniferous, or the Permian, is about 1,500 feet. A section measured by Peale ${ }^{2}$ on Eagle River is as follows:

Section of "Permo-Carboniferous" rocks on Eagle River, Colo.

Shaly sandstone, pink, brown, and gray, with interlaminated beds of blue limestone, about..................

Shaly sandstone and limestone, alternating colors pink, brown, gray, yellow, white, cream, and blackish. These beds are best shown on the north side of the river. They incline generally about $60^{\circ}$. In some places they are inclined past the vertical in the upper portion. Thickness about................................. 
Gypsiferous shale and sandstone. The gypsum occurs in great quantity, and it is rather impure. The sandstone is laminated and generally of a pink or red color. Apparent thickness of outcrop...........................

Feet. $500-800$

$$
1,200-1,500
$$

The thickness of the gypsiferous series appeared to the writer to be greater rather than less than the maximum of $\dot{8} 00$ feet given above. The predominant color of the gypsiferous shale is gray, and that of the gypsum beds is an ashy gray which can be recognized for many miles. As noted in the local descriptions, the inclination of the gypsum beds is in most places rather steep. Peale considers that the gypsiferous series is probably tipped up with the overlying beds, and makes the following statement: "It is difficult here to reduce the [gypsiferous] strata to any order. Their softness has caused them to yield readily to eroding influences, and they have weathered into low hills in which they are for the most part concealed. There are one or two folds in them of some extent. *** Besides, however, there are numerous minor foldings which would require more time than we could give to reduce them to any system." Peale considers that the gypsiferous beds on Eagle River and on Fryingpan Creek, as well as those along Grand River above the mouth of the Eagle River, belong to the same series.

The gypsum masses appear to be lenses of various dimensions interbedded with shale and to occur at no definite horizons. The lenses range in thickness from a few feet up to 200 feet or more. They generally contain shale bands or beds mixed with the gypsum, and the gypsum probably contains more or less impurity, chiefly in the form of lime, alumina, and silica. The gypsum masses have resisted weathering slightly better than the inclosing beds of shale and in many places they project as ledges or faint ridges, but the gypsum also weathers rapidly and is inclined to slump down in large masses and mix with the shale, so that it is difficult to ascertain the true thickness of any depusit of gypsum, or to determine what its condition in the unweathered or rock form may be.

\section{LOCAL DESCRIPTIONS.}

One-half to three-fourths of a mile southeast of Gypsum station gypsum outcrops in a hill on the west side of the Gypsum Creek valley. (See fig. 45.) The outcrop strikes north or slightly west of north, and the dip is generally rather steep toward the east, although in places the beds stand nearly vertical or dip steeply toward the west. The apparent area of outcrop of the bed may have been increased through overturning and sliding of masses down the hill. The outcrop occurs on the axis and east flank of a low ridge, which is cut in two by a.gully, giving good exposures of the 
edges of the gypsum beds. The material is massive rock gypsum, rather soft on the exposed edges on account of weathering, so that the material has crumbled to a powder in many places. The color is generally grayish, but where unweathered the rock is lighter than the weathered material. Both the rock gypsum and the soft. weathered material effervesce with hydrochloric acid, the powder effervescing the more briskly. The thickness of the bed appears. to be at least 150 feet here; the length of the exposure is about 1,500 feet and the height ranges from 25 to 150 feet. About 20 carloads of gypsum are reported to have been quarried here and

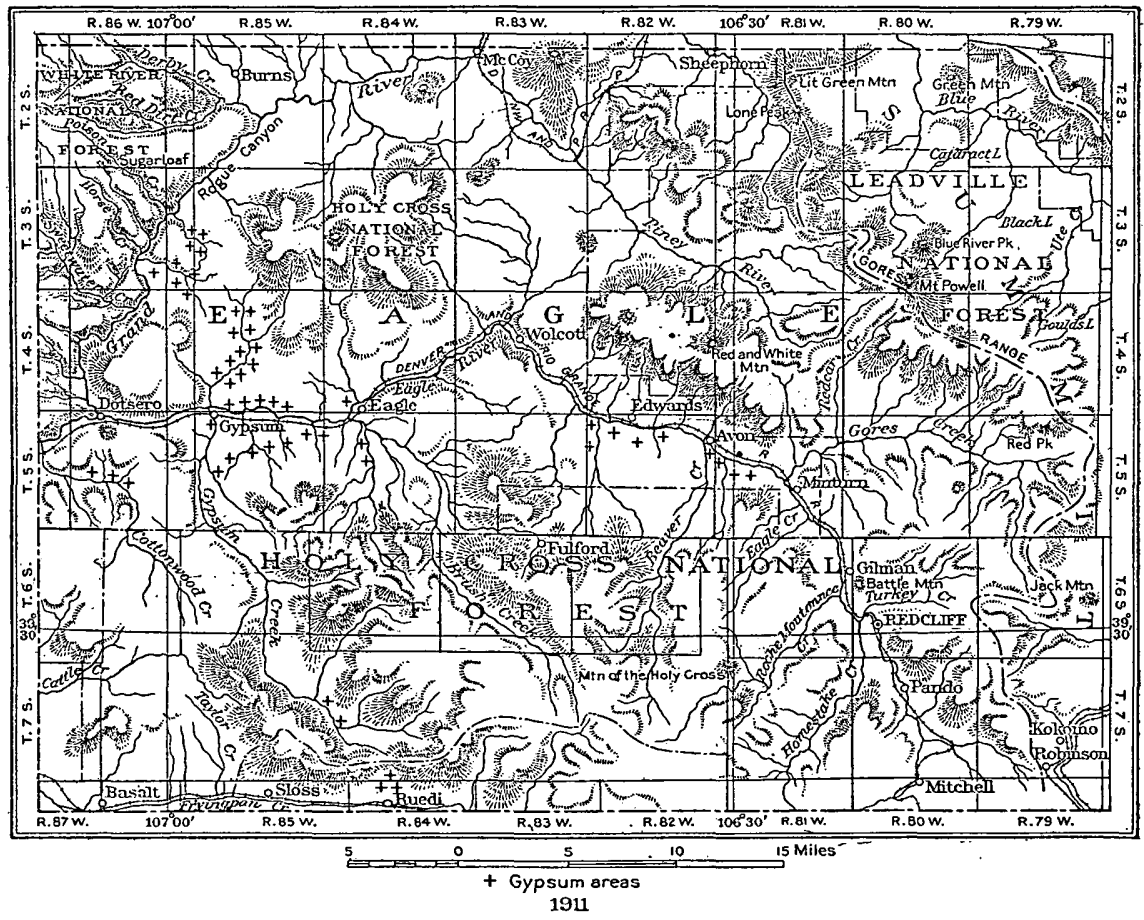

FIGURE 45.-Map showing areas of gypsum in Eagle County, Colo. (From General Land Office map of Colorado, 1910.)

shipped to Portıand, Colo., in 1906 and 1907, for use in the manufacture of Portland cement. The old quarry shows a face about 100 feet high and 150 feet wide at the base of a small spur. There is very little overburden, except a cover of impure gypsite 1 foot to 10 feet or more in thickness. An analysis furnished by Mr. A. Kollquist, of Gypsum, Colo., showed the following constituents: Silica, 0.2 per cent; ferric oxide and alumina, 0.1 per cent; calcium sulphate, 78.8 per cent; water, 20.9 per cent. (See also analysis No. 1, p. 365.)

About 3 miles south of Gypsum station, on the east side of the Gypsum Creek valley, some gypsum-bearing beds outcrop. The 
formation is composed of greenish-gray shale. The beds strike about $\mathrm{N} .35^{\circ} \mathrm{E}$. and dip generally toward the southeast at moderate angles. There are no extensive single beds of gypsum here. On the low hill at the east of the road there are two small outcrops separated by shale. Some of the gypsum thus showing has probably had its outcrop enlarged by slumping down and spreading out. The haul to the railroad is rather too long for immediate development, although it is down a gentle grade on good wagon road.

In the north bluffs of the Cottonwood Creek valley are exposed several gypsum beds beginning at a point 3 miles above the mouth of the creek and extending for more than 3 miles upstream. This locality is about 8 miles from Gypsum station. The general strike is from northwest to southeast, and the dip is about $15^{\circ} \mathrm{NE}$. The beds lie generally high in the bluffs or at the very top. Much of the associated rock appears to be a hard gypseous material with interbedded layers of black shale. (See analysis No. 3, p. 365.) Three gypsum beds were noted in this locality. The dip of the beds carries their plane too high to intersect the bluffs on the opposite side of the creek. The lower part of the valley of Cottonwood Creek becomes a canyon between walls of hard, fractured, blue limestone, which weathers brown on the surface. Fossils collected from this limestone have been determined by E. M. Kindle to be of Upper Devonian age, belonging to the Ouray fauna, and the rock resembles most closely the limestone which represents the lower part of the Ouray limestone near Glenwood Springs. The possibility of the commercial development of these beds is very doubtful under present conditions, for it would be practically impossible to build a railroad or tramway up Cottonwood Creek canyon. Haulage over the divide to Gypsum station is also impracticable under present conditions, as there is so much gypsum accessible along Gypsum Creek. It is reported that in the canyon of Gypsum Creek in T. 7 S., R. 84 W., about 15 miles southeast of Gypsum, gypsum is exposed for about 4 miles. These deposits were not visited, as they are so remote and inaccessible as to be of no commercial importance for many years, if at all. Over the divide, on the north side of Fryingpan Creek, are important deposits on the line of the Colorado Midland Railroad, which are described on page 363.

On the north side of Eagle River, $2 \frac{1}{2}$ miles above Gypsum, a number of lenses of gypsum are exposed in the river bluffs. The general strike of these beds is about $\mathrm{N} .65^{\circ} \mathrm{W}$., and they have a steep northeastward dip. The beds are much bent by folding and slumping over. The beds are inclosed in calcareous to sandy shale, and the exposure of one of the largest masses shows a total thickness of about 140 feet across the beds, as shown on the next page. 
Section of gypsum beds and associated strata $2 \frac{1}{2}$ miles east of Gypsum.

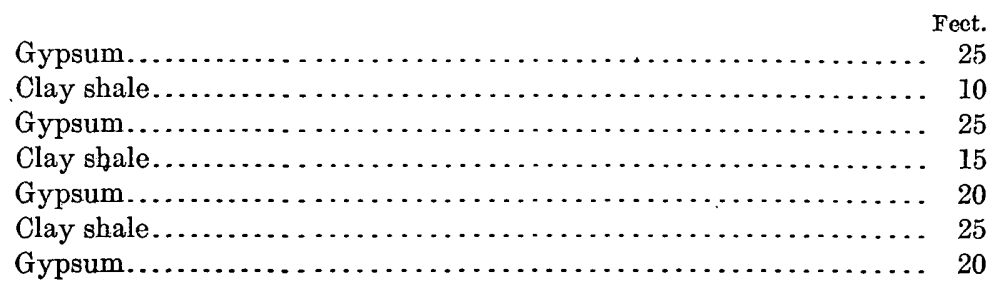

The height of this bluff is about 250 feet. The gypsum is darkgray shaly material. Near the top of the series the beds are extremely hard, but lower down the material is in many places very soft and earthy. When treated with hydrochloric acid it gives a faint effervescence. The gypsum contains much selenite in medium-sized crystals, and some dark shaly bands also contain selenite crystals. The three partings of clay shale are calcareous. There is very little o.verburden on top of this bluff, as the beds are exposed along the strike, but a heavy talus of gypseous clay lies in front of the face of the exposure, extending to a height of 75 to 150 feet above the flood plain of Eagle River. The deposits are about three-fourths of a mile from the Denver \& Rio Grande Railroad, on the opposite side of the river. An analysis (No. 2, p. 365) of a small sample of rock gypsum from this locality showed that the sample was anhydrite. It is not probable that anhydrite constitutes the whole or even a large part of this deposit, but the fact that it is present is significant and emphasizes the necessity for thorough sampling.

Northward from Gypsum station, along an abandoned wagon road that leads from Eagle River to Grand River, gypsum shows in large masses, outcropping in the hillsides, in the gullies, and on mountain tops for about 4 miles back from Eagle River. All the surface material is so weathered and washed down that it is nearly impossible to distinguish the limits of the gypsum beds within 15 to 25 feet of accuracy, or to determine their exact dip and strike. In general the strike seems to be between $N .5^{\circ} \mathrm{W}$. and $N .45^{\circ} \mathrm{W}$., although in places the beds seem to have a more westerly trend. The material is locally very selenitic. At the top of one large bluff, about $1 \frac{1}{2}$ miles from Eagle River, large blocks of selenite, from which plates 15 inches square might be split, were noted. Large masses of gypsum have slumped down from the outcrops and appear thus to be in places at levels which are lower than the actual position of the beds. The soft, weathered gypsum mixes so readily with the soft calcareous shale which incloses it that it is almost impossible to ascertain from surface appearances just what the true relation of the mass of gypsum may be unless it can be traced for a long distance in the direction of the strike. It is therefore necessary to prospect these beds on a rather large scale in order to determine their true thickness and extent. In 
places beds seem to dip in opposite directions on opposite sides of a divide, but the dips appear mainly to be toward the northeast, and range from $20^{\circ}$ up to vertical. The thickness of the more important beds of gypsum, so far as it could be determined, ranges from 100 to 200 feet, and many single beds may be traced for one-fourth to threefourths of a mile. There are at least three beds of importance, and there may be several more. The rocks include many thin beds of gypsum and some beds of dark gypsiferous shale. The strip of land 3 or 4 miles wide, including the divide between the Eagle River and Grand River basins, appears to be composed of a limy shale and thin limestone, carrying little or no gypsum. It is covered by a growth of cedar and piñon, which do not flourish on gypsiferous soils. At the summit are remnants of a flow of hard dark-brown vesicular basalt. On the slope toward Grand River gypsum is present in abundance. Between the ravines locally known as Trail Gulch and Sheep Gulch enormous masses of it appear in all attitudes in the bluffs, capping them for long stretches; in other places outcropping on the flanks and dipping into the hills; also lying in masses on the flanks and near the bases of the hills, evidently the result of landslides. In Trail Gulch large deposits occur within $1 \frac{1}{2}$ miles of Grand River. In Sheep Gulch the gypsum is not so abundant and in places has a dark color and carries interbedded black carboniferous shaly material. (See analysis No. 4, p. 365.)

None of the deposits on the slope toward Grand River will be commercially important until a railroad is built down Grand River from McCoy to Dotsero, but it is reported that two surveys have been made through this area and that a line is a possibility in the future. It would connect the Denver, Northwestern \& Pacific Railway with the Denver \& Rio Grande Railroad. In working such deposits as these cable tramways might be used, and such a method of transporting the material would be almost necessary, for track tramways might be washed out by high water in the gulches after heavy rains.

Three miles southwest of Eagle, on the south side of the Eagle River valley, one-eighth of a mile from the Denver \& Rio Grande Railroad, are several exposures of gypsum in the bluffs. The beds stand nearly vertical, strike about $\mathrm{N} .70^{\circ} \mathrm{W}$., and are inclosed in shale. The gypsum is grayish to white, with much soft, decomposed material on the surface and talus slopes. One of the most promising exposures has been located as a placer claim by persons living at Redeliff, Colo. The bed is 80 to 100 feet thick, with a face 30 to 100 feet high, and is exposed about 550 feet on the strike. There is a large supply of gypsum in this locality, several more beds having been noted in the hills between this point and the village of Eagle. Altogether the gypsumbearing formation is exposed for about $1 \frac{1}{2}$ miles between Eagle and Gypsum. (See analysis No. 5, p. 365.) 
At Avon, in the bluff at the junction of Eagle River and Beaver Creek, is a large exposure of gypsum. The beds strike about N. $60^{\circ} \mathrm{E}$. and dip at a moderate angle toward the northwest. The rock underlying these beds is shale containing chert. There are two beds here, the lower one being about 130 feet thick and the upper one 50 to 75 feet thick; they are separated by 40 to 50 feet of clay, calcareous shale, and shaly limestone. The lower bed is mainly light-grayish rock gypsum of a subcrystalline texture where unweathered. It contains some small, hard dark masses of impure gypsum. All the material is highly calcareous. The lower two-thirds of the upper bed is largely crystalline selenite in aggregates of crystalline masses onehalf inch to 3 inches long. The exposure of these gypsum beds extends for at least one-fourth mile along the bluff of Beaver Creek. To quarry the gypsum it would be necessary to remove in places 40 to 50 feet of clay and calcareous shale or shaly argillaceous limestone where it projects beyond the upper bed. It is reported that claims have been filed by residents of Avon but that there is considerable gypsum remaining on Government land. The base of the gypsum lies about 350 feet above the level of the valley. A cable tramway about 1,500 feet long would reach a mill site near the railroad. A mill could be built on the hillside below the gypsum outcrop, but to connect it with the railroad a spur and a bridge over Eagle River would be necessary.

Above Avon, on the southwest side of the Eagle River valley, within 2 miles there are 10 or 12 outcrops of gypsum masses, which are not so well exposed, however, as the one at Avon. There are probably not so many distinct beds of gypsum as there are outcrops of this material. Most of them are near the base of the bluff and many of them probably represent masses that have slumped down from a concealed bed at higher levels. About one-fourth mile southeast of the Beaver Creek exposure a bed shows at the top of a high point, and from the stratigraphic relations it is evidently a higher bed than the one at Beaver Creek. It is evidently of about the same thickness as the one described, and both of them may be traced for a mile or so southeast by outcrops or bare spots showing decomposed gypsum at levels corresponding with the relative positions of these beds. The most favorable place, however, for a mill in connection with a large workable deposit of gypsum in this locality is near the mouth of Beaver Creek at Avon. There is apparently a sufficient flow of water in Eagle River to furnish water power for a mill, unless more water is raken for irrigation.

From Avon toward Edwards several more outcrops of gypsum show on the south side of the Eagle Valley. One that is well exposed is directly opposite Edwards, between one-half and three-quarters of a mile from the Denver \& Rio Grande Railroad. About $1 \frac{1}{2}$ miles below 
Edwards, gypsum beds show in places for a mile in the west bluffs of South Eagle River, and gypsum-bearing rocks are present to a point in the valley about 2 miles below Edwards. The dip in this locality is generally toward the west, and the red formations of the Triassic overlying the gypsum-bearing series appear with westerly dips beyond this point, so that no more gypsum beds show toward the west until the vicinity of Eagle is reached.

Altogether the outcrop of gypsum-bearing rocks along Eagle River in this vicinity extends at least $7 \frac{1}{2}$ miles. In places the beds have been repeated by folding and by faulting.

Over the divide south of the Gypsum Creek drainage basin, at the extreme edge of Eagle County, on the north side of Fryingpan Creek, at Ruedi, the Roaring Fork Plaster Co. is developing the only deposit of gypsum that is worked in the county. Ruedi is on the line of the Colorado Midland Railroad, which serves a somewhat different trade territory from that traversed by the Denver \& Rio Grande Railroad, therefore the probabilities of strong competition between mills on the two roads are not great. The gypsum occurs in a mountainous mass of sediments which strike N. $15^{\circ} \mathrm{W}$. to N. $25^{\circ} \mathrm{W}$. and dip from $30^{\circ}$ to $60^{\circ} \mathrm{SW}$. As exposed in the quarry the gypsum beds are generally thick and are jointed and fractured. Shale and limestone are interbedded in the formation above the quarry, but prospect openings at short intervals for half a mile from the quarry back to the summit of the mountain show that a very large proportion of the rock is gypsum. The summit of the ridge lies at least 1,400 feet above the valley level, and parallel to the valley the gypsum has been traced for at least a mile. On the south side of the valley, in Pitkin County, two small prospects show impure gypsum, but the material does not seem to be abundant in this direction. The gypsum as quarried is a light to darkgray and white rock gypsum, some of which is massive. It is mostly rather fine grained and hard. It contains some very hard streaks and pockets of dark material that seem to be mainly gypsum, and also some concretions of shale. In a few places clay seams have developed along joint planes that have been enlarged by solution. Faint traces of sulphur show on the surface of some of the darker beds in the quarry. The dark color has been thought possibly to be due to carbonaceous residue. An analysis of this gypsum is given on page 365 (No. 6).

The quarry openings are on the east and west sides of a small gully, and the floor is on a level with the top of the mill. The faces of the two openings are about 100 feet wide and 80 feet high. The rock is blasted down with both black powder and dynamite, and it is necessary to reshoot the large blocks of gypsum. The stripping of soil and soft gypsum, which ranges from a few inches to 7 or 8 feet in thickness, is shoveled down into the quarry, carried out by cars, and 
dumped at one side of the track. The gypsum is moved from the quarry to the mill in steel tram cars, which are let down an incline. by cable. A train of two loaded cars hauls up two empties. The capacity of the cars is about 2,200 pounds each. From 65 to 70 tons of rock is quarried a day under normal conditions by six men. For the best white-coat finish and plaster of Paris the rock is selected by hand. The dark and hard material is rejected and some of it must be culled out by hand. The cars are dumped sidewise into the rock bin at the mill. The rock is first passed through an Ehrsham jaw crusher and a rotary grinder and is carried by screw conveyor and elevator to three cylindrical steel storage bins, having a capacity of about 30 tons each. From these bins the material is fed to three rawgrinding burr mills. From the burrs the ground material is conveyed by cars and elevators either direct to the kettles or to a storage bin for raw-ground material. From this bin the material may be drawn off and elevated to the kettles. There are two 10-foot kettles having a capacity of 15 tons each. Two charges are run daily, making the total capacity of the mill 60 tons in nine hours, but the full capacity is seldom reached. The kettles are fired with so-called lump coal from Cardiff, Colo., and pea coal is used for the boilers. The calcined material is drawn from the base of the kettles into adjoining hot pits built of local red sandstone. Screw conveyors and steel elevators convey the plaster from the hot pits to an inclined shaking. screen. The fines go direct to the stock bins, and the overs go to the regrinding bin. From the regrinding bin the material is moved by a screw conveyor and chute to a regrinding burr mill. This mill discharges its product into an elevator that carries the material to a screw conveyor leading to the steel stock bins, which have separate compartments for wall plaster, molding plaster, and plaster of Paris. From the stock bins screw conveyors and elevators move the material to mixing bins. These bins supply the mixing hopper with plaster by a bottom feed. The operative who runs the mixer adds to the plaster definite quantities of retarder, hair, wood fiber, etc., as the order may demand. The mixing machine stirs the material by means of paddles and allows it to pass downward into a compartment, from which it is fed directly into sacks. Two mixing machines are installed, although only one is generally used. The accessories in the mill are a wood-fiber machine and a hair picker: Quaking aspen and cottonwood, both local woods, are made into fiber. 


\section{ANALYSES.}

The following analyses of gypsum from Eagle County were made by John G. Fairchild, of the United States Geological Survey, in March, 1911:

Analyses of gypsum from Eagle County, Colo.

\begin{tabular}{|c|c|c|c|c|c|c|}
\hline & 1 & 2 & 3 & 4 & 5 & 6 \\
\hline $\mathrm{SiO}_{2} \ldots$. & 0.24 & Trace. & 16. 55 & 3.90 & 4. 38 & 0.05 \\
\hline $\mathrm{Fe}_{2} \mathrm{O}_{3}+\mathrm{Al}_{2} \mathrm{O}_{3} \ldots \ldots \ldots \ldots \ldots \ldots \ldots \ldots \ldots \ldots \ldots \ldots$ & .18 & Trace. & $\begin{array}{r}2.81 \\
10.42\end{array}$ & 2.29 & 1.86 & .13 \\
\hline $\begin{array}{l}\mathrm{CaO} \ldots \\
\mathrm{SO}_{3} \mathrm{O}_{2} \\
\mathrm{H}_{2} \mathrm{O} \\
\text { Organic matter } \ldots \ldots\end{array}$ & \begin{tabular}{r|}
32.60 \\
4.80 \\
19.62 \\
1.11
\end{tabular} & \begin{tabular}{r|}
40.61 \\
56.82 \\
1.87 \\
.46
\end{tabular} & $\begin{array}{l}10.42 \\
27.80 \\
6.24 \\
3.40 \\
6 \pm\end{array}$ & $\begin{array}{r}34.56 \\
32.61 \\
14.54 \\
2.99\end{array}$ & $\begin{array}{r}30.74 \\
40.40 \\
18.62 \\
.75\end{array}$ & $\begin{array}{r}32.94 \\
44.23 \\
20.30 \\
.25\end{array}$ \\
\hline
\end{tabular}

1. Half a mile south of Gypsum, Colo.

2. Two and one-half miles east of Gypsum, Colo. Nearly anhydrite.

3. Cottonwood Creek, 8 miles west-southwest of Gypsum, Colo.

4. Eight miles north of Gypsum, Colo.

5. Eagle, Colo.

6. Ruedi, Colo. 


\section{SURVEY PUBLICATIONS ON GYPSUM AND PLASTERS.}

The more 1mportant publications of the United States Geological Survey on gypsum and plasters are included in the following list. These publications, except those to which a price is affixed, can be obtained free $\mathrm{by}$ applying to the Director, United States Geological Survey, Washington, D. C. The priced publications may be purchased from the Superintendent of Documents, Government Printing Office, Washington, D. C.

Adams, G. I., and others. Gypsum deposits of the United States. Bulletin 223. 123 pp. 1904. 25c.

Boutwell, J. M. Rock gypsum at Nephi, Utah. In Bulletin 225, pp. 483-487. 1904. 35c.

Burchard, E. F. Gypsum and gypsum products. In Mineral Resources U. S. for 1909, pt. 2, pp. 639-647. 1911.

Darton, N. H., and Siebenthal, C. E. Geology and mineral resources of the Laramie Basin, Wyoming, a preliminary report. Bulletin $364 . \quad 81$ pp. 1909.

EcKeL, E. C. Gypsum and gypsum products. In Mineral Resources U. S. for 1905, pp. 1105-1115. 1906. \$1.

Harder, E. C. The gypsum deposits of the Palen Mountains, Riverside County, Cal. In Bulletin 430, pp. 407-416. 1910.

HEss, F. L. A reconnaissance of the gypsum deposits of California. Bulletin 413. 37 pp. 1910.

Gypsum deposits near Cane Springs, Kern County, California. In Bulletin 430, pp. 417-418. 1910.

Richardson, G. B. Salt, gypsum, and petroleum in trans-Pecos Texas. In Bulletin 260 , pp. 573-585. 1905. 40c.

Shaler, M. K. Gypsum in northwestern New Mexico. In Bulletin 315, pp. 260265. 1907. 50c.

Siebenthal, C. E. Gypsum of the Uncompahgre region, Colorado. In Bulletin 285, pp. 401-403. 1906. 60c.

Gypsum deposits of the Laramie district, Wyoming. In Bulletin 285, pp. 404-405. 1906. 60c. 


\section{LIME AND MAGNESITE.}

\section{SURVEY PUBLICATIONS ON LIME AND MAGNESITE.}

In addition to the papers listed below, which deal principally with lime, magnesite, etc., further reference on limestones will be found in the lists given under the heads "Cement" and Building stone." These publications, except the one to which a price is affixed, can be obtained free by applying to the Director, United States Geological Survey, Washington, D. C. The priced publication may be purchased from the Superintendent of Documents, Government Printing Office, Washington, D. C.

BAstin, E. S. The lime industry of Knox County, Me. In Bulletin 285, pp. 393-400. 1906. 60c.

Burchard, E. F., Butts, Charles, and Ecked, E. C. Iron ores, fuels, and fluxes of the Birmingham district, Alabama. Bulletin 400. 204 pp. 1910.

Burchard, E. F. Lime. In Mineral Resources U. S. for 1909, pt. 2, pp. 543-555. 1911.

Butts, Chardes. Limestone and dolomite in the Birmingham district, Alabama. In Bulletin 315, pp. 247-255. 1907.

Calkins, F. C., and MacDonald, D. F. A geologic reconnaissance in northern Idaho and northwestern Montana. Bulletin 384.112 pp. 1909.

Hess, F. L. Some magnesite deposits of California. In Bulletin 285, pp. 385-392. 1906. $60 \mathrm{c}$.

The magnesite deposits of California. Bulletin $355 . \quad 67$ pp. 1908.

Rres, H. The limestone quarries of eastern New York, western Vermont, Massachusetts, and Connecticut. In Seventeenth Ann. Rept., pt. 3, pp. 795-811. 1896.

YALE, C. G. Magnesite. In Mineral Resources U. S. for 1909, pt. 2, pp. 841-843. 1911. 


\section{GLASS SAND, ETC.}

\section{SURVEY PUBLICATIONS ON GLASS SAND AND GLASS- MAKING MATERIALS.}

The list below includes the important publications of the United States Geological Survey on glass sand and glass-making materials. These publications, except those to which a price is affixed, can be obtained free by applying to the Director, United States Geological Survey, Washington, D. C. The priced publications may be purchased from the Superintendent of Documents, Government Printing Office, Washington, D. C.

Burchard, E. F. Requirements of sand and limestone for glass making. In Bulletin 285, pp. 452-458. 1906.

- Glass sand of the middle Mississippi basin. In Bulletin 285, pp. 459-472. 1906.

Glass-sand industry of Indiana, Kentucky, and Ohio. In Bulletin 315, pp. 361-376. 1907.

- Notes on glass sands from various localities, mainly undeveloped. In Bulletin 315, pp. 377-382. 1907.

Fenneman, N. M. Geology and mineral resources of the St. Louis quadrangle. Bulletin 438.73 pp. 1911.

Phalen, W. C., and Martin, Lawrence. Mineral resources of Johnstown, Pa., and vicinity. Bulletin 447, 140 pp. 1911.

Srose, G. W. Glass-sand industry in eastern West Virginia. In Bulletin 285, pp. 473-475. 1906.

Weezs, J. D. Glass materials. In Mineral Resources U. S. for 1883-1884, pp. 958-973. 1885. 60c.

40c.

Glass materials. In Mineral Resources U. S. for 1885, pp. 544-555. 1886. 


\section{ABRASIVES.}

\section{SURVEY PUBLICATIONS ON ABRASIVE MATERIALS.}

The following list includes a number of papers, published by the United States Geclogical Survey or by members of its staff, dealing with various abrasive materials. The Government publications, except those to which a price is affixed, can be obtained free by applying to the Director, United States Geological Survey, Washington, D. C. The priced publications may be purchased from the Superintendent of Documents, Government Printing Office, Washington, D. C.

Arnold, Ralph, and Anderson, Robert. Diatomaceous deposits of northern Santa Barbara County, Cal. In Bulletin 315, pp. 438-447. 1907. 50c.

Chatard, T. M. Corundum and emery. In Mineral Resources U. S. for 1883-84, pp. 714-720. 1885 . 60c.

Eckel, E. C. The emery deposits of Westchester County, N. Y. In Mineral Industry, vol. 9, pp. 15-17. 1901.

Holmes, J. A. Corundum deposits of the southern Appalachian region. In Seventeenth Ann. Rept., pt. 3, pp. 935-943. 1896.

JENKS, C. N. The manufacture and use of corundum. In Seventeenth Ann. Rept., pt. 3, pp. 943-947. 1896.

PARKer, E. W. Abrasive materials. In Nineteenth Ann. Rept., pt. 6, pp. 515533. 1898.

Phalen, W. C. Abrasive materials. In Mineral Resources U. S. for 1909, pt. 2, pp. 609-628. 1911.

Pratt, J. H. The occurrence and distribution of corundum in the United States. Bulletin 180. $98 \mathrm{pp}$. 1901. 20c.

- Corundum and its occurrence and distribution in the United States. Bulletin 269. 175 pp. 1905. (Bulletin 269 is a later and revised edition of Bulletin 180.)

RABORG, W. A. Buhrstones. In Mineral Resources U. S. for 1886, pp. 581-582. 1887. 50c.

Grindstones. In Mineral Resources U. S. for 1886, pp. 582-585. 1887. 50c.

Corundum. In Mineral Resources U.S. for 1886, pp. 585-586. 1887. 50c. 
370 CONTRIBUTIONS TO ECONOMIC GEOLOGY, 1910, PART I.

READ, M. C. Berea grit. In Mineral Resources U. S. for 1882, pp. 478-479. 1883. 50c.

Siebenthal, C. E., and Mesler, R. D. Tripoli deposits near Seneca, Mo. In Bulletin 340, pp. 429-437. 1908.

Turner, G. M. Novaculite. In Mineral Resources U. S. for 1885, pp. 433-436. 1886. 40c.

pp. 589-594. 1887. 50c.

Woolsey, L. H. Volcanic ash near Durango, Colo. In Bulletin 285, pp. 476-479. 1906. 60e. 